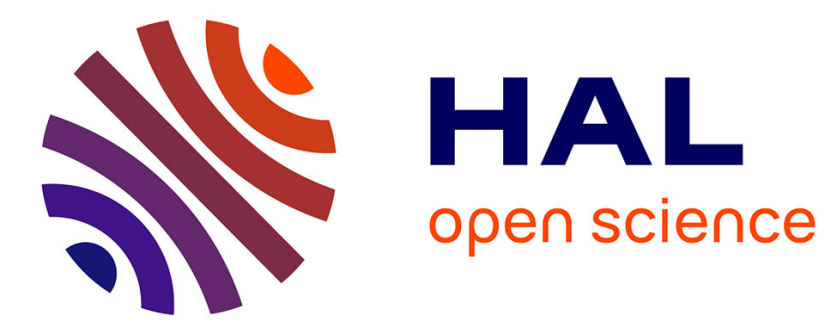

\title{
Phenolic foams: A review of mechanical properties, fire resistance and new trends in phenol substitution
}

C. Mougel, T. Garnier, P. Cassagnau, N. Sintes-Zydowicz

\section{To cite this version:}

C. Mougel, T. Garnier, P. Cassagnau, N. Sintes-Zydowicz. Phenolic foams: A review of mechanical properties, fire resistance and new trends in phenol substitution. Polymer, 2019, 164, pp.86 - 117. 10.1016/j.polymer.2018.12.050 . hal-03486760

\section{HAL Id: hal-03486760 \\ https://hal.science/hal-03486760}

Submitted on 20 Dec 2021

HAL is a multi-disciplinary open access archive for the deposit and dissemination of scientific research documents, whether they are published or not. The documents may come from teaching and research institutions in France or abroad, or from public or private research centers.
L'archive ouverte pluridisciplinaire HAL, est destinée au dépôt et à la diffusion de documents scientifiques de niveau recherche, publiés ou non, émanant des établissements d'enseignement et de recherche français ou étrangers, des laboratoires publics ou privés.

\section{(c) (1) $\$$}

Distributed under a Creative Commons Attribution - NonCommercial| 4.0 International 


\title{
Phenolic foams: A review of mechanical properties, fire resistance and new trends in phenol substitution
}

\author{
C. Mougel ${ }^{1,2}$, T. Garnier $^{2}$, P. Cassagnau ${ }^{1}$, N. Sintes-Zydowicz ${ }^{1}$ \\ ${ }^{1}$ Université de Lyon, Université Claude Bernard Lyon 1, CNRS UMR 5223, Ingénierie des Matériaux \\ Polymères, F-69622 Villeurbanne Cedex, France \\ ${ }^{2}$ Robatel Industries, 12 rue de Genève - CS 80011, 69747 Genas Cedex, France \\ Correspondence to: N. Sintes-Zydowicz (nathalie.sintes@univ-lyon1.fr) \\ Keywords: Phenolic foam, compressive strength, flexural strength, friability, limiting oxygen index, \\ heat release rate
}

\begin{abstract}
Phenolic foams (PF) have a combination of properties that make them attractive for a number of engineering applications such as insulation, lightening, energy absorption and fire protection. Phenolic foams exhibit excellent fire-retardant behaviour but have insufficient mechanical properties (e.g. fatigue, flexural properties and friability) for different applications in comparison to other foam materials. Hence, numerous studies have tried to improve these mechanical properties without deteriorating its excellent fire-retardant behaviour. Different approaches have been investigated, such as the addition of fibres and particles or the chemical modification of the PF base resin. This work will first briefly present generalities from resin synthesis to foam production. The main part will review the existing papers dealing with the improvement of the compressive and flexural strength as well as the friability. Moreover, evolution of the cell size with these mechanical properties will be presented, although there is no well-defined link between them. Then, the influence of these modifications on the fire-retardant behaviour of PF will be discussed. Finally, the last part will present work to substitute phenol from petroleum sources to environmental friendly sources.
\end{abstract}




\section{Introduction}

Nowadays, polymeric foams are being developed due to their great potential in several applications, such as thermal and sound insulation, packaging, filter systems, structural and domestic elements [1]. The benefits provided by the reduction in mass compared to dense solid materials are numerous. For example, they enable energy savings during transport by lightening the structures [2] and in insulation due to better performance [3]. All these properties help to reduce the environmental impact.

Phenol-formaldehyde materials were first discovered in 1872 by the German chemist Adolph Von Baeyer [4]. In 1907, the use of phenolic resins, also known as Bakelite, was developed by L.H. Baekeland, the "father of the phenolic resins" [5, 6]. In the early 1940s, phenolic foams (PF) were first introduced and used in German industry as a balsa material substitute [7]. Over time, they became less popular with the emergence of others materials, such as polyurethane, polyvinyl chloride or polystyrene foams, which offered less brittleness and friability [8, 9]. However, with the new fire restrictions, industrial segments identified an urgent need to substitute the abovementioned foams due to their weak fire resistance and the toxic gases formed during combustion. Hence, phenolic foams regained an interest due their very satisfying fire retardant behaviour [10, 11]. However, PF suffers from some mechanical weaknesses because their rigidity also makes them brittle and highly friable. For that reason, numerous studies [12-14] have focused on the improvement of the final foam mechanical properties, such as compressive strength, flexural strength and friability, while still maintaining attractive fire resistance.

Nevertheless, to the best of our knowledge, no review has been yet reported on the PF modification effects on the final mechanical properties. The objective of this review is to offer an exhaustive synthesis of the literature studies dealing with the improvement of PF properties. First, general insights on the phenolic foams are introduced, from the resin synthesis to the foam production and curing processes. Then, the improvement of PF mechanical properties (compressive strength, flexural strength and friability) is reviewed. The flame retardancy improvements reported in the literature are then described (limiting oxygen index and peak of heat release rate). The last part of this paper gives information on the latest trends for substituting the phenol by biomass-based resol resin as a sustainable material. 


\section{Phenolic foams: from resin synthesis to foam production}

\subsection{Phenolic resins}

Phenolic resins are used worldwide. In terms of volume, the global phenolic resins market stood at approximately 4.7 million tons in 2014. The world consumption of phenolic resins evaluated in volume at approximate USD 10.0 billion in 2014 is expected to reach approximately USD 14.0 billion by 2020 [15]. The following pie chart shows world consumption repartition in volume in 2017 (Figure 1).

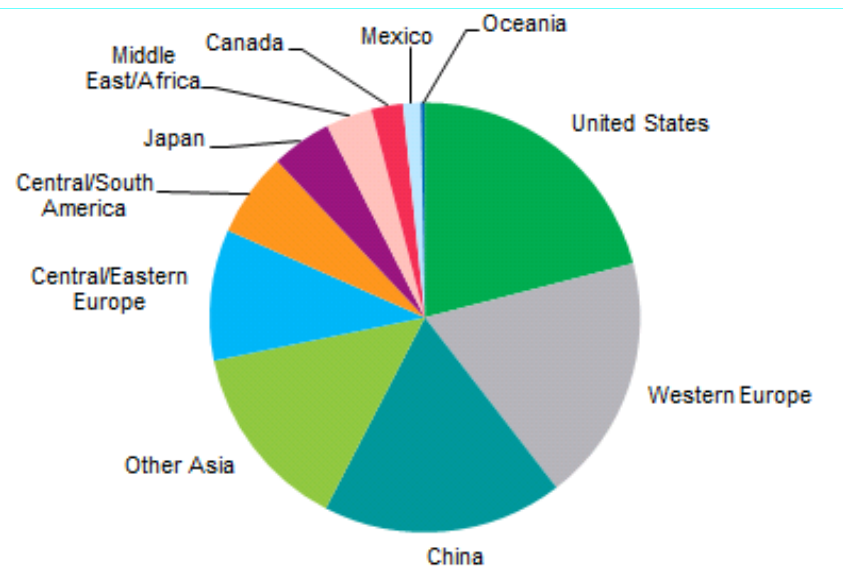

Figure 1. World consumption in volume of phenolic resins in 2017 [16].

Phenolic resins are available in different forms, e.g. moulding powders to produce electrical equipment for building and household appliances as well as liquid resins to obtain laminates, binders or adhesives for agglomerated wood or fibre reinforced composite materials [11]. Their unique chemical structure offers an excellent fire-retardant behaviour. Once exposed to a flame, these resins release very low amounts of smoke and toxic fumes and are well known for their natural tendency to form a porous carbonaceous substance that provides a barrier effect $[11,14,17]$. For this reason, phenolic resins are also used as composite matrices in civil transport for railways, aeronautics and shipbuilding (for interior fittings, seats and aircraft parts); offshore platforms (for protection of steel infrastructures) and in the aerospace industry (for carbon-fibre composite propellant thrusters) [11].

Phenolic resins are synthetic polymers produced by polycondensation between phenol and formaldehyde. Phenol is a solid material at room temperature $\left(\mathrm{T}_{\mathrm{m}}=43^{\circ} \mathrm{C}, \mathrm{Bp}=182{ }^{\circ} \mathrm{C}\right)$ with three reactive $\mathrm{C}-\mathrm{H}$ bonds: two in ortho $(\mathrm{O})$ positions and one in the para $(\mathrm{P})$ position. For phenolic resin synthesis, mono-substituted phenols may sometimes be used since they decrease the average 
valence of the precursor and thus the crosslinking density of the final material. Among these substituted phenols, there is cresol, resorcinol, p-alkylphenol, p-phenylphenol and bisphenol A [18]. These structural modifications increase the toughness of the final resin [18]. The commercial form of formaldehyde used for phenolic resins manufacturing is an aqueous solution containing generally from $37 \%$ up to $52 \%$ of formaldehyde stabilized with methanol [19].

The reaction between phenol and formaldehyde is exothermic and depends on the $\mathrm{pH}$ of the mixture, catalyser and reactant molar ratio. The latter exerts a decisive influence on the resin structure, viscosity, reactivity and density, its crosslinking and the residual monomer content [20, 21].

When using an acid catalyst with a molar ratio F/P lower than 1, novolac-type resins are obtained (Figure 2). These resins are only reactive in presence of catalysts, and therefore they are considered relatively stable [11].

Under basic conditions and with a molar ratio of formaldehyde to phenol (F/P) higher than 1, resoltype resins are obtained (Figure 2). This family is reactive due to the presence of methylol groups at the end of the chains and can be cured once exposed to temperature. Hence, precautions have to be taken for the storage of these resins in order to avoid their polymerization [20,21]. Resol resins are the most used for foam production and hence, this paper will only deal with this type of resins.

\section{Resol}

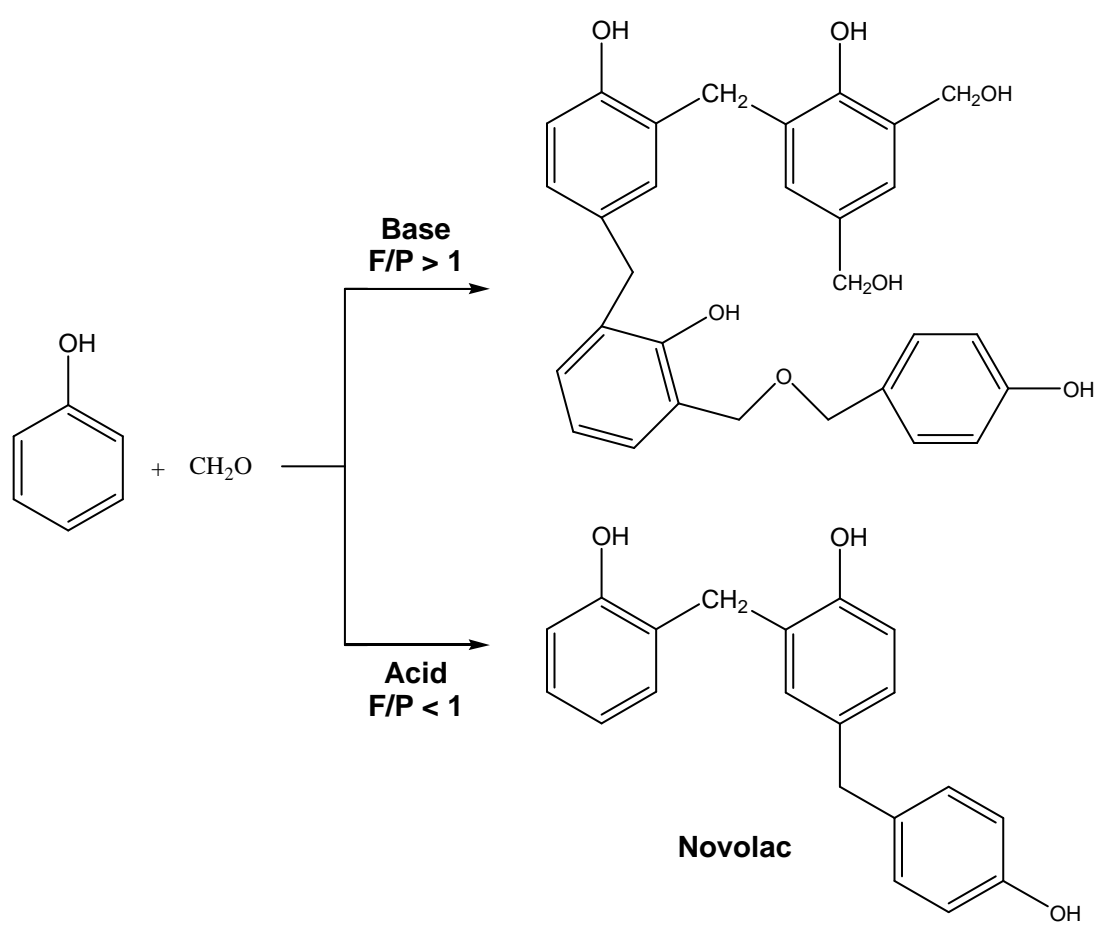


Figure 2. Synthesis conditions for producing resol and novolac resins [11].

Figure 3 shows phenoxide ions obtained from the phenol structure under alkaline conditions $[16,17$, 20]. The most common alkaline catalyst is sodium hydroxide. However, other alkali, earth alkali hydroxides and basic amines, such as triethylamine or hexamethylenetetramine, can also be used $[20,21]$. In alkaline media, the hydroxyl function of the phenol is deprotonated to form a hydroxylate function [22]. These hydroxylate functions have a more pronounced electro-donor mesomeric effect than the hydroxyl functions, and therefore they strongly activate the nucleophilic character of the carbon atoms located in the ortho and para positions.

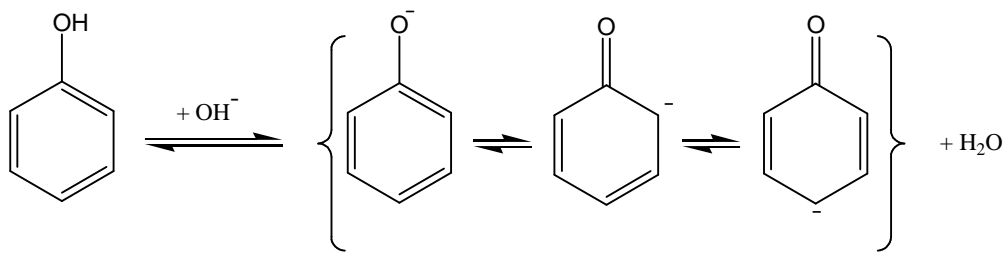

Figure 3. Under alkaline conditions, the base catalyses the reaction by converting the phenol into the more reactive phenoxide ion [20-22].

Resol resin synthesis begins once the phenoxide ion reacts with formaldehyde, leading to the formation of methylol functions (Figure 4). The ortho and para phenol reactive positions lead to a mixture of phenol alcohols that might also react [11].

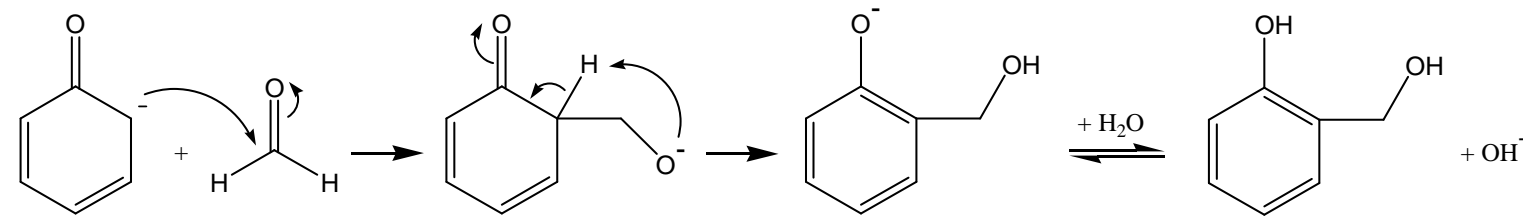

Figure 4. Mechanism reaction between phenoxide ion and formaldehyde to form methylolphenol [22].

Methylol functions are also activating, so functionalized phenolic compounds are more reactive to formaldehyde than non-functionalized compounds [23]. Moreover, the presence of alkaline catalysts stabilizes the synthesized methylol functions [23] and promotes the formation of phenolic compounds with several methylol functions (Figure 5) [20, 21].<smiles>OCc1ccccc1O</smiles><smiles>OCc1ccc(O)cc1</smiles><smiles>OCc1cccc(CO)c1O</smiles><smiles>OCc1ccc(O)c(CO)c1</smiles><smiles>OCc1cc(CO)c(O)c(CO)c1</smiles>

Figure 5. Different possible forms of methylolphenols [20, 21]. 
Methylolphenols then convert into a methide intermediate [24] to react by condensation with a phenol (Figure 6, route I) or other methylol functions (Figure 6, route II). These reactions result in the formation of methylene bonds or dimethyl ether bonds [25]. These ether bonds are converted into methylene bonds with formaldehyde emission during curing [26].

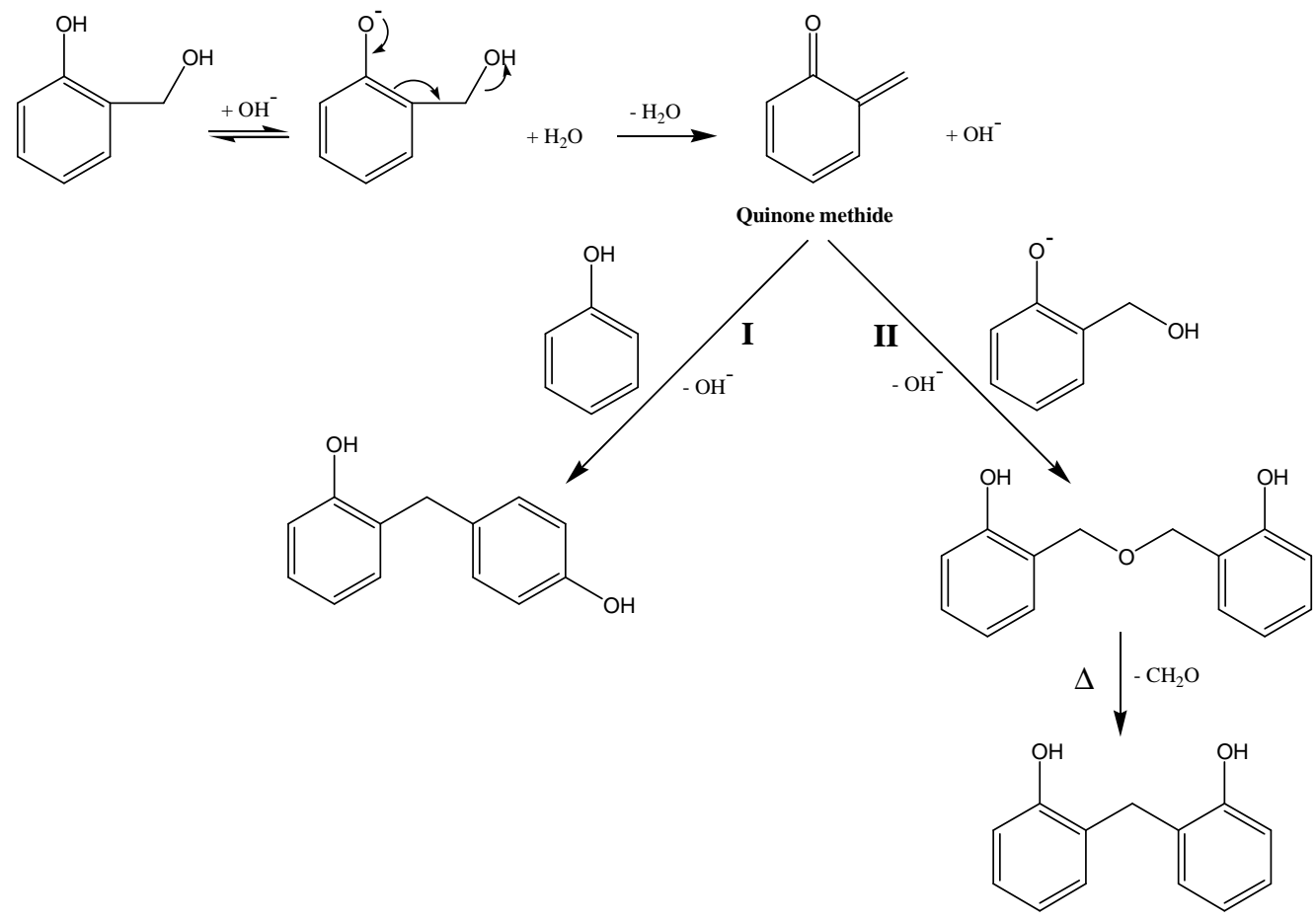

Figure 6. Condensation mechanisms [22].

The significant number of isomers for a given chain length, as well as the chemical pathways make the kinetics very complex and provide partially crosslinked complex phenolic resol resin containing macromolecules with different molar masses, degree of substitution of methylol groups, methylene bridges or dimethylene ether bridges and structures (Figure 7).<smiles>O=Cc1ccc(O)c(Cc2cc(Cc3cc(CO)c(O)c(Cc4cc(CO)c(O)c(Cc5cc(C=O)cc(CO)c5O)c4)c3)cc(COCc3cc(CO)ccc3CO)c2O)c1</smiles>

Figure 7. Example of final structure of resol resin [27]. 
All of these characteristics can be tailored in order to fulfil specific requirements by changing the synthesis parameters, such as the formaldehyde to phenol ratio, catalyst, reaction temperature and time. The lifetime and the stability of the resin depend highly on the storage temperature.

Different resins are obtained once the reaction is stopped. Depending on the network polymerization degree, the following may occur:

- At low molar mass, liquid and highly reactive resins are obtained.

- At higher molar mass, the obtained resins are used in generally alcoholic solutions, e.g. methanol, ethanol, isopropanol, butanol and furfuryl alcohol. Their solubility depends on their molar mass and solvent nature.

- At very high molar mass, the final resins are crushable solids and are commercialized under different forms, e.g. powders, scales, pellets or pieces.

The average number molar mass varies from 125 to 150 g.mol ${ }^{-1}$ for aqueous resins to more than 1000 g.mol ${ }^{-1}$ for solid resins. Their differences make it possible to adapt them to a wide range of applications. In general, for foam applications the resin molar mass is around $350 \mathrm{~g} \cdot \mathrm{mol}^{-1}$.

\subsection{Phenolic foams}

The specific properties of phenolic foams allow them to be exploited for some highly specialized applications, such as decontamination (nuclear, polluted water) or the manufacture of space shuttles. Their economic weight is substantial and the global insulation market is in the billions of euros. Polymeric foams generally consist of two phases, or more. One is a gaseous phase dispersed in a solid polymer matrix, such as rubbers, elastomers, thermoplastics or thermosets. Furthermore, the foams can be classified as a flexible, semi-flexible, semi-rigid or rigid material, according to the rigidity of the polymer backbone. This, in turn, depends on the chemical composition and the polymer matrix characteristics, such as degree of crystallinity and crosslinking.

Physical and mechanical properties of foams significantly differ from those of dense materials (Figure 8). Indeed, foams can enable a larger scope of applications compared to dense solids, thanks to a wide range of properties [28]:

- Low densities make it possible to manufacture light structures with rigid components.

- Low thermal conductivity ensures reliable and economical insulations.

- Low rigidity makes foams attractive for energy absorbing applications. 


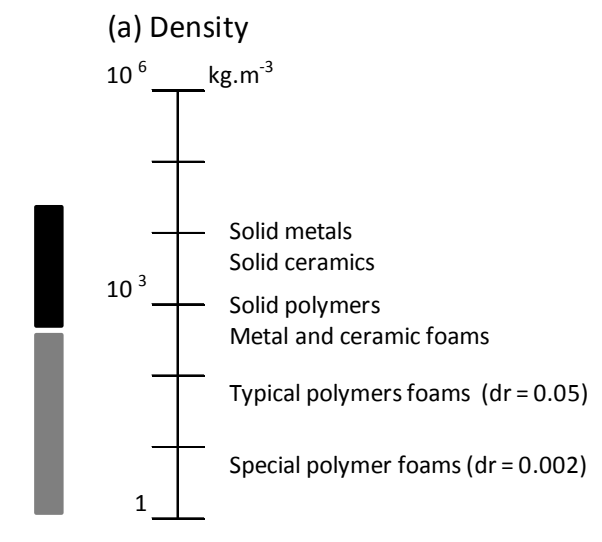

(c) Compressive strength

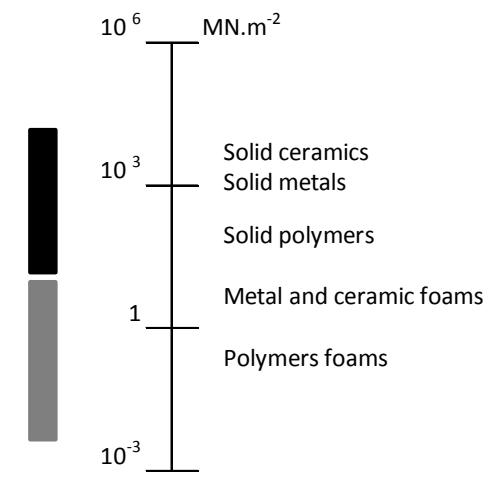

(b) Young's modulus

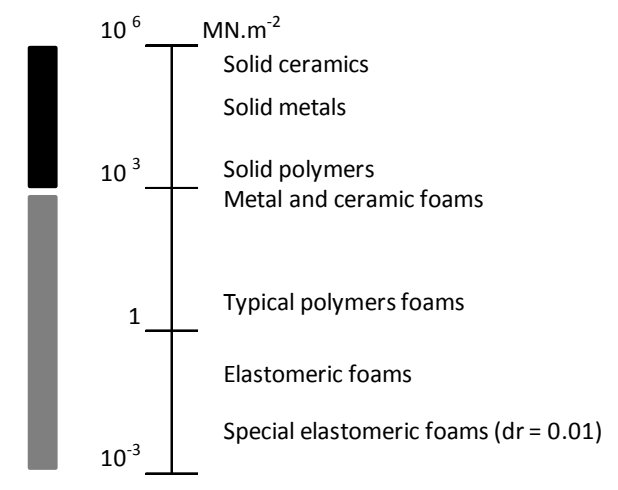

(d) Thermal conductivity

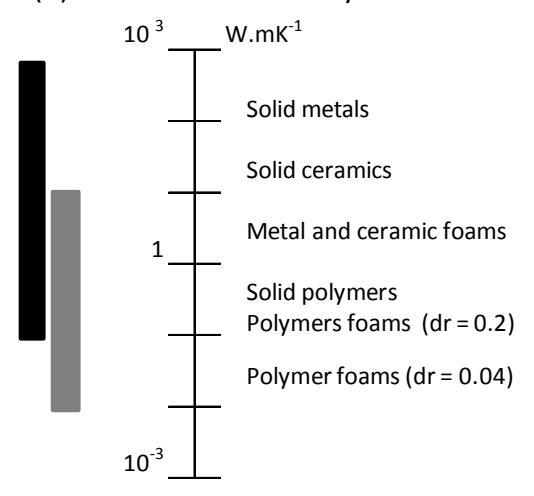

Figure 8. Range of properties of the foams and solids of which it is composed: (a) density (b) Young's modulus (c) compressive strength (d) thermal conductivity [29].

The cell geometry (i.e. open/closed, size and shape) greatly influences the foam final properties. For example, closed cells are more suitable for thermal insulation while open ones are preferred for sound insulation applications [28].

Among commercial foams, PF are known to be rigid thermosetting foams. They possess high thermal stability, good thermal insulation, excellent fire resistance, no dripping behaviour and low production of toxic gases during combustion [30]. However, and as mentioned before, the brittleness and pulverization tendencies of PF severely restrict their applications [31]. It is therefore crucial to improve the overall mechanical properties of these foams, while maintaining their excellent fireretardant behaviour. Two routes allow the improvement of the PF mechanical properties. The first one relies on the foam formulation. The nature and the amount of each component in the formulation can be adjusted in order to optimize the foam final properties for a given process [4, 11 , $21,32,33]$. Furthermore, other constituents can be added to the formulation to tailor the properties. For example, fibres are introduced to improve compressive and flexural strengths [34]. Also, 
polyethylene glycol addition enhances ability of the cell walls to deform [13, 14] and a nucleating agent or thin particles are added in order to increase the cell density [35-37]. Moreover, the fire resistance property is improved due to the addition of flame retardants [38]. The second route passes through the choice of the production process. A free rise mode that uses an open mould will favour a high content of open cells and an inhomogeneous density, whereas the use of a closed mould may lead to a more controlled density and possibly a high content of closed cells [11].

\subsection{Foam formulation}

Phenolic foam manufacturing can be achieved by mechanical, physical or chemical methods [1]. Commonly used foaming methods include:

- Thermal decomposition of a blowing-agent that generally generates $\mathrm{N}_{2}, \mathrm{CO}_{2}$ or both when the temperature increases due to external heating or an exothermic reaction [1].

- Volatilization of gaseous products produced during the exothermic polymerization reaction (e.g. isocyanate reacts with water to form $\mathrm{CO}_{2}$ ) [1] .

- Volatilization of a low-boiling solvent, such as a fluorocarbon, methylene chloride, pentane or ether in the foam mixture upon an exothermic reaction or by external heating [1].

- Mechanical agitation of gaseous products in a polymer system, such as molten, solution or suspension that cures either by the action of a catalyst, by heating or both, trapping the bubbles in the polymer matrix [1].

- Expansion of gas-filled beads by external heating or exothermic reaction (e.g. polystyrene beads in a polyurethane or epoxy resin system) [1].

- Expansion of a dissolved gas in the mass of a polymer by reducing the system pressure, such as $\mathrm{CO}_{2}[1,39]$.

- Incorporation of hollow microspheres into the foaming mixture as hollow glass or hollow plastic beads [1].

For PF production, the most used method consists of volatilizing a solvent with a low boiling point. The volatilization of gases produced during the exothermic polymerization reaction or the thermal decomposition of chemical blowing agents by heating has been reported [11].

In addition to the phenolic resin, an emulsifier, blowing agent, catalyst and optionally some additives are involved in the preparation of PF. Among the additives, plasticizers, fibres [40], micro- or nanoparticles [41] are often used. 
The foam formation is controlled by the competition between two mechanisms, namely the expansion of the blowing agent and the curing of the resin that may simultaneously occur. Thus, the viscosity and the reactivity of the phenolic resin are two key parameters in the PF formation. On one hand, low viscosity should allow the resin to be easily injected using industrial pumps and should not be a limiting factor during mixing. On the other hand, higher viscosity may control the cell growth and potentially limits the coalescence. The influence of the viscosity has been reported to influence structural characteristics of the PF such as the wall thickness, size of the cells or the creation of macro-defects $[11,42,43]$. Moreover, a viscosity that is too high can impede the foam expansion and lead to a density that is higher than expected.

The resin reactivity, as well, controls the curing and the foaming processes [4]. Indeed, if the reactivity is too high, the foams will cure before the foaming is completely achieved and the final foam density will be different than the one expected. Moreover, other resin parameters can also impact the final foam properties, such as the $\mathrm{pH}$, water content [44], and monomer amount [21].

Emulsifiers are also of great importance since they help to control the foam quality and properties. Their role is to generate a stable and homogeneous oil-in-water emulsion between the blowing agent and the phenolic resin that will govern the foam cell characteristics. The main challenge of an emulsifier is to assure the emulsion stability throughout the foaming process, which includes the temperature increase, viscosity evolution and state change of the blowing agent $[11,32]$. Polyethylene glycol sorbitan monooleate, a non-ionic surfactant commercially known as Tween 80 $[38,43,45]$, is mostly used. Silicon oil $[46,47]$ was reported as an alternative to Tween 80. Sometimes two emulsifiers are used (one in water and one in oil) to achieve the required final quality of the emulsion $[48,49]$. They generally help or facilitate the opening of the foam cells. Indeed, the addition of anionic surfactant [49] helps to break the resin droplets that encapsulate the blowing agent. It also acts as a demulsifier that gently vaporizes the blowing agent outward during bubble collision and combination, resulting in an interconnected open-cell pore structure [49].

Blowing agents are known to induce foaming of the phenolic resin through physical or chemical processes. Carbon dioxide $\left(\mathrm{CO}_{2}\right)$ has been reported as in situ formed blowing agent, especially in the case of resol foam formulations $[29,50]$. It may be formed by the reaction of carbonates with the acid catalyst $[11][51,52]$ or by the reaction of water with isocyanate added in small amount. Blowing agents that act by physical processes are classically low boiling point liquids that evaporate, inducing the formation of gas bubbles in the phenolic matrix when the temperature rises due to the 
heating of the reactive mixture and/or the exothermic reaction between the resin and the acid catalyst. These foaming agents are the most commonly used.

The blowing agent type will influence the foam cell structure, forming either open or closed cell foams (Figure 9). The selection of the blowing agent type depends on the final application and the foam cell type required. High volatile hydrocarbons are known to induce the formation of open cells. The high volatility of these products and the open cell structure favour their removal after the foam production step and limit the risk of explosion. Pentane $[30,41]$ is the most used blowing agent in PF production, whereas the use of cyclopentane [42], hexane [33] and petroleum ethers [12] is less mentioned (Table 1).

Table 1. Main foaming agents used for PF, excluding chlorofluorocarbons (CFC) and hydrochlorofluorocarbons (HCFC).

\begin{tabular}{c|c} 
Foaming agent & Boiling point $\left({ }^{\circ} \mathrm{C}\right)$ \\
\hline $\mathrm{n}$-pentane & 36 \\
Petroleum ether & 49 \\
Cyclopentane & $42-62$ \\
Hexane & 68 \\
Diisopropyl ether & 69
\end{tabular}

For closed-cell foams that are classically used for building insulation applications, the blowing agent stays trapped in the cells. Hence, its choice is a key factor since its thermal conductivity will influence the insulation properties of the final foam [11]. Another property of interest is the remaining time of the blowing agent inside the foam but unfortunately this topic is poorly reported in the literature. Chlorofluorinated blowing agents [53] were largely used for many years but have been progressively replaced since Montreal [27] and Kyoto [54] Protocols by pentane blends or isomers that present no environmental issues and are cost-effective.
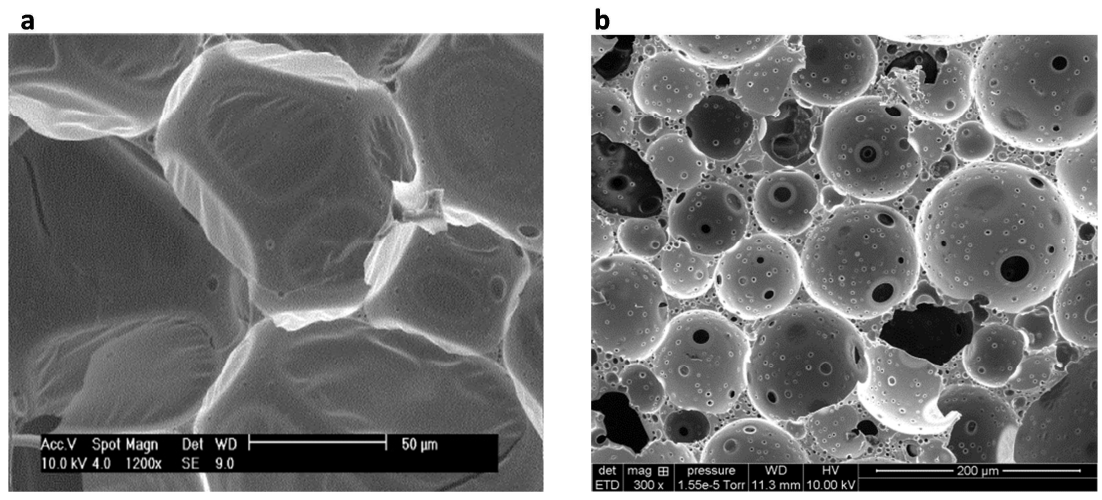

Figure 9. Closed cell type (a) [55] and open cell phenolic foams (b) ${ }^{\circledR}$ FENOSOL - Robatel Industries. 
Catalysts required for the resol based PF accelerate the curing reaction of the resin by reducing its gelation time and taking part in the foam expansion. Nowadays, organic acids, such as p-toluene sulfonic acid [36] and phenol sulfonic acid [56], are preferred to highly corrosive inorganic acids, such as sulphuric acid or hydrochloric acid [57]. Blends of organic acids, containing small amounts of inorganic acids such as sulphuric or phosphoric [58], are largely used in order to increase the reaction rate and/or to improve the flame retardant of the foam.

Other different additives can be added to the formulation, such as plasticizers, flame retardants, thickeners or fillers according to the targeted application. The effects of different plasticizers have been investigated for overcoming the PF friability. Polyethylene glycol-based products are the most common plasticizers $[12,13,59]$. Despite intrinsically high PF fire resistance, some applications and environmental restrictions require the addition of flame retardants, usually phosphorous, nitrogen or boron-based products $[13,38,41,59]$. Thickener additives modify the viscosity of the formulation and help to fix the material on the deposited surface. This avoids the possibility of flowing or dripping by increasing the viscosity of the formulation. This is important, especially in spray-foam systems [11]. Fillers are well known to enhance the foam mechanical properties and reduce the material final cost. In the case of PF, the aim is to increase the foam compressive resistance and decrease the foam friability. Clay [52], glass fibres [10], aramid fibres [10, 57], multiwall carbon nanotubes (MWCNT) [60] and many other natural, inorganic or organic fillers enable the improvement of one, or more, of the targeted properties but with different final costs. Attempts to use natural fillers, such as cellulose [56], lignin or wood floor particles, [61] were also reported in the literature, although their incorporation can slightly decrease the thermal stability above $300{ }^{\circ} \mathrm{C}$ and potentially the fire resistance of the PF. Besides the improvement of the previous mechanical properties, the addition of fillers increases the reactive mixture viscosity. Furthermore, the filler nature, geometry and amount will significantly impact the foam expansion $[11,30]$.

In conclusion, numerous PF formulations can be prepared according to the targeted application due to the incorporation of additives or fillers. Hence, attention must be paid to the impact of each component on the final characteristics of the PF.

\subsection{Foam production processes}

Industrially, PF are produced through batch, continuous or semi continuous processes [11]. Recently, an unconventional process was developed known as microwave foaming, $[17,62]$ but it has not been scaled up to industrial manufacturing to the best of our knowledge. 
The batch process is the easiest and least expensive process to implement industrially despite a high operating cost [11]. First, the resin, emulsifiers and other additives are mixed together in an appropriate container using a simple rotating paddle-type stirrer. Next, the obtained master batch is mixed with the blowing agent and the acid catalyst. Finally, the foaming mixture is directly poured into a mould for the foaming step, where the form and the size of the moulds vary according to the application. The foaming process usually requires external heating $\left(50-80^{\circ} \mathrm{C}\right)$ to concurrently expand and cure the resin [11].

The mould can be open or closed. With an open mould, the foams expands in a free rise mode leading to non-reproducible production of non-homogeneous foams with different densities [4]. Closed mould limit the foam expansion causing the increase of pressure and temperature, and allows control in a reproducible manner the form and the density of the foam. High closed cell content foams are obtained [4].

Once the curing step is completed, the foam blocks are demoulded and additional drying and postcuring are performed according to the targeted application. This supplementary step leads to a higher curing degree since the curing reaction kinetics are relatively slow and need several hours to be achieved [11]. Attention must be paid to the removal of the water that was produced during the curing, in order to displace the reaction equilibrium and increase the crosslinking degree [63]. This will also avoid further evolution of the foam properties.

The continuous foaming process is more expensive to implement industrially but requires less operations and produces foams with a higher quality and reproducibility. The principal parameter in this process is the mixing head and its characteristics. A continuous flow of the different components feeds the mixing head and the different moulds are filled and placed on a conveyor line [64]. Two major designs are found for mixer heads, namely low-pressure dynamic mixing heads and highpressure static mixing heads [11]. Low-pressure mixing heads are most commonly associated with a type of mechanical mixer called a peg stirrer. This system produces a substantial amount of foam mixtures in a short time and with a constant quality.

For high-pressure mixing heads, the impingement mixing technique is used. These heads consist of a mechanism that pushes the different components forward through injectors, under high pressure, in order to increase the velocity of the components (mixed in a small mixing chamber). The high velocity ensures the homogeneity of the mixture $[11,55]$. These mixing heads are known to produce a more homogeneous mixture and a finer cell structure than low-pressure mixing heads [11]. Despite 
the simple maintenance, this mixing type is not commonly used for industrially production of PF because of the high cost.

A semi-continuous process combines the two techniques mentioned above. This technique requires less investment and produces foams with a consistent good quality even for small-scaled production.

Microwave foaming technology was recently reported by Song et al. $[17,65]$ as a quite simple and cost-effective process. First, the different components are mixed by using an impeller at high speeds (500 rpm) for several minutes, the mixture is left to undergo ageing at room temperature and finally the foaming process is carried out using a microwave device. The authors explain that activated carbon [65], graphene or MWCNT [17] are added to the resin to control the cell size by trapping the generated gases, such as the water vapor, that are produced during the curing process. They are also added to reinforce the foam structure. Thus, no blowing agent is required.

The last step in the foam production process is the curing step. Two phenomena must be considered, namely the curing of the resin and the expansion of the blowing agent as they occur simultaneously. A curing rate faster than the expansion rate induces a heterogeneous structure and a high-density foam. On the other hand, a relatively slow curing rate should favour coalescence of the bubbles, a decrease in the compressive and flexural strengths and an increase in the friability. Moreover, equilibrium must be shifted to obtain a high level of crosslinking. To do that, water from the phenolic resin and resulting condensation reactions has to be removed. Thus, it is crucial to adapt the process conditions (curing time, curing temperature) and the formulation parameters (concentration in catalyst, amount of blowing agent) in order to concurrently control the curing and the expansion kinetics $[66,67]$.

The curing of phenolic resol foam can be performed under acidic or thermal conditions, but both are classically used in order to accelerate the curing reaction [1]. During the curing step, the phenolic resin passes through the critical transition called gelation that involves the abrupt increase of the mass-average molar mass and viscosity of the system. At the same time, the blowing agent volatilization allows the foam mixture to expand. The PF mixture viscosity continues to increase, and hence foaming has to be completed before the system becomes completely crosslinked. A complete cure of phenolic resol leads to a high modulus, high crosslink density, moderately high $\mathrm{T}_{\mathrm{g}}$ and strong heat resistance [16]. The final structure of a cured phenolic resol resin is shown in Figure 10. It can be seen that the reactive methylol groups have almost disappeared because they were consumed through condensation reactions during the curing step [1]. 


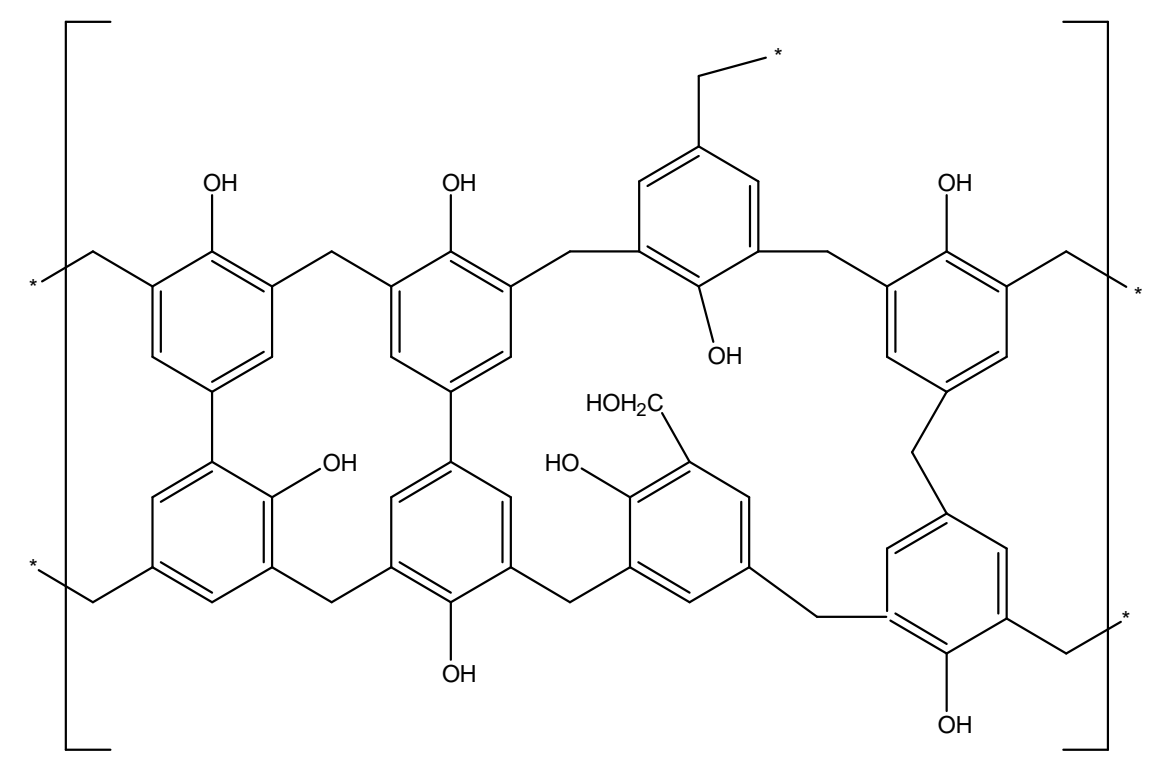

Figure 10. Example of structure of a cured resol resin.

\section{Improving phenolic foam mechanical properties}

Phenolic foams usually present lower mechanical properties, such as compressive and flexural strengths, and higher friability than other common foams such as polyurethane or polystyrene foams. As a consequence, several papers have been reported that deal with the improvement of these properties by increasing the compressive strength and flexural strength and decreasing the friability. In this part, the solutions proposed in the literature regarding the improvement of these properties will be reviewed. Two approaches are provided, namely the chemical modification of the $\mathrm{PF}$ and the addition of fillers.

The density is a crucial factor to consider when discussing mechanical properties of foams. For example, Ashby et al. [29] have modelled the behaviour of elastic, plastic and brittle foams under compression. Their models emphasize the effect of density on this behaviour. Under compression, foams follow stress-strain curves composed of three stages. After an initial elastic behaviour, a long plateau takes place at almost constant stress during which cells are crushed. Finally, a densification regime occurs where the stress suddenly increases.

As a rigid foam, PF are also concerned by the variation of the compressive stress versus the strain according to the density. Figure 11 shows the effect of the relative density (0.12 to 0.30$)$ on the experimental compression curves of $\mathrm{FENOSOL}^{\mathrm{TM}}$ phenolic foams. The curves show the same tendency as those predicted by Ashby. More precisely, all the curves are characterized by three 
regimes: i) the regime of linear elastic at low strain, ii) a relatively long plateau due to the collapse of the cell under stress and finally iii) the regime of the densification of the cellular solids under compression. On the other hand, it is worth noting that the Young's modulus and the compressive strength increase significantly with the increase in the density.

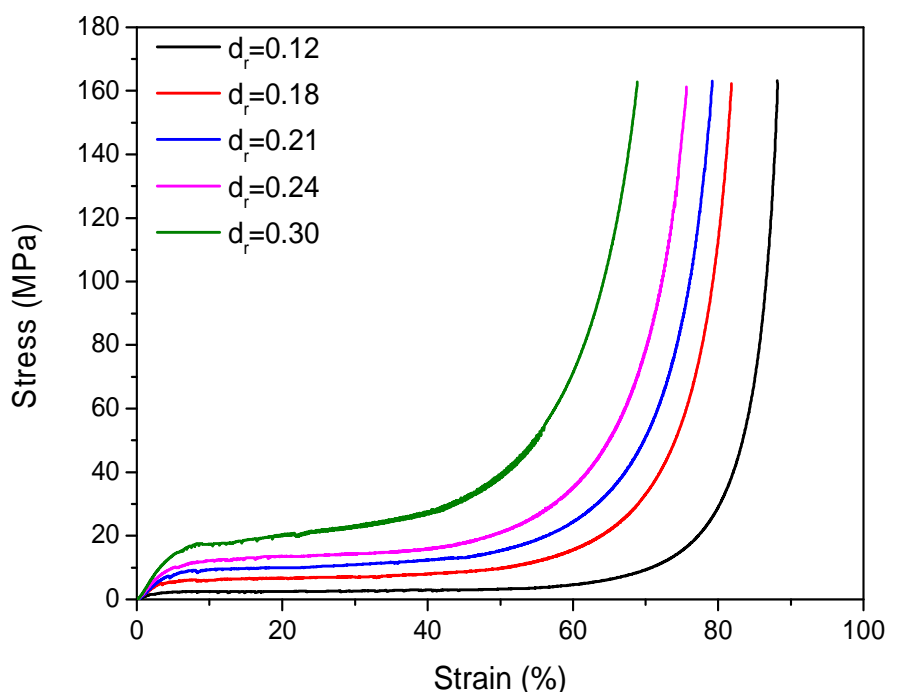

Figure 11. Compressive stress as a function of strain for different FENOSOL ${ }^{\mathrm{TM}}$ foam relative densities.

Nevertheless, literature reports sometimes do not specify the density values or if it is a dry density. This is important because PF contains a non-negligible mass of water that can evolve with time. Moreover, comparing foams with densities that are not in the same range also occurs. Hence, it can be problematic draw firm conclusions about the effect of the modification. Furthermore, if the densities are mentioned, they are often lower than 0.1. Only few papers deal with densities higher than $0.1[40,52,56,61]$.

Moreover, the filler parameters, such as size, shape and surface specific area, are of great importance and could change the final properties of the material. However, some authors do not indicate the properties of the fibres or fillers, such as dimensions and mechanical characteristics. Hence, it is unfortunately complicated to determine their respective effect on the final mechanical properties.

Regarding chemical modification, the foams are generally cured at $80^{\circ} \mathrm{C}$. There are exceptions for those that are cured at $70{ }^{\circ} \mathrm{C}$ and use an acid. Moreover, it is impossible to establish the stoichiometric relation between the $\mathrm{OH}$ functions of the phenolic resin and the reactive functions of the modifier because the amount of $\mathrm{OH}$ function is not quantified by the authors. Nevertheless, the modifier content is usually between 0 and $10 \mathrm{wt} \%$. 
This second part will start with a short presentation of Gibson and Ashby's model for compressive properties in order to highlight the strong influence of the density on these properties. Then, the influence of the cell size on compressive properties will be discussed in relation to Gibson and Ashby's model. Then, the results found in the literature for PF will be presented. Finally, the improvement of compressive, flexural and friability properties of PF due to different modifications will be analysed through the literature to determine the most relevant modification and thus identify the parameters that most influence the mechanical properties.

\subsection{Gibson and Ashby model}

Compressive strength is strongly dependent on the foam relative density (Figure 11), and the foremost model to show the relation between them has been proposed by Gibson and Ashby [29]. They expressed the Young's modulus and the compressive stress in the plateau region as a function of the relative density by distinguishing three kinds of foams, namely elastomeric, elasto-plastic and elasto-brittle. They also classified two kinds of form structures, namely open and closed cell.

The first step of the model is to simplify the complex structure of the foam using a geometric model. At the simplest level, an open-cell foam can be shown schematically as a cubic array of struts (or edges) of length, $I$, and thickness, $t$. The struts have a square cross-section. The adjacent cells are positioned so that their struts are connected in the middle. The cellular structure in real foams is obviously more complex, but their properties can be understood using dimensional arguments that omit all constants resulting from a specific cell geometry.

Foams with closed cells are more complicated. If the cell faces are thin enough, they will rupture easily. Hence, the foam behaviour will be identical to that of an open-cell foam. Nevertheless, some polymers give foams in which a substantial fraction of the solid is contained in the cell faces and contributes to the stiffness. In that case, the edge thickness, $t_{e}$, and the face thickness, $t_{f}$ as well as the fraction of solid in the edges, $\Phi$, are considered.

\section{Linear elastic domain}

Gibson and Ashby consider that in the regime described by the elasticity theory, a compressed open cells foam deforms by elastic bending of the horizontal struts and without buckling of the vertical struts. Young's modulus, $E^{*}$, is thus defined by the Equation 1:

$$
\frac{\mathbf{E}^{*}}{\mathbf{E}_{\mathrm{s}}}=\mathbf{d}_{\mathbf{r}}^{2}
$$

where $E_{s}$ is the Young's modulus of the dense material and $d_{r}$ is the relative density 


\section{Elastic collapse stress}

The output of the linear range is caused by elastic instability, namely buckling of the vertical walls at $\sigma_{e l}$, as shown in Equation 2. The collapse of elastic open-cell foams occurs at almost constant stress, resulting in a long plateau in the stress-strain curve:

$$
\frac{\sigma_{\mathrm{el}}}{\mathrm{E}_{\mathrm{s}}}=0.05 \mathrm{~d}_{\mathrm{r}}^{2}
$$

To collapse elastically, closed cell foams have to overcome the buckling load, such as for open cell types, and the compression of the fluid contained in the cells. This will change the collapse stress, $\sigma_{e l}$ and causes the "plateau" stress to rise with strain.

\section{Plastic collapse stress}

Foams that are made from materials that exhibit elastic-plastic behaviour (e.g. rigid polymers or metals) plastically collapse beyond the linear-elastic regime. This is delimited by the plastic collapse stress, $\sigma_{p l}$, as shown in Equation 3. This phenomenon, like elastic buckling, gives a horizontal plateau to the stress-strain curve. The vertical struts do not buckle but the hinges deform in a plastic way:

$$
\frac{\sigma_{\mathrm{pl}}}{\sigma_{\mathrm{ys}}}=0.23 \mathrm{~d}_{\mathrm{r}}^{3 / 2}
$$

\section{Crushing collapse stress}

Fragile foams (for example, ceramics, glasses and some fragile polymers) collapse through another mechanism. Beyond a certain stress applied to the foam, noted as $\sigma_{c r}$ in Equation 4, the cell edges break:

$$
\frac{\sigma_{\mathrm{cr}}}{\sigma_{\mathrm{fs}}}=0.2 \mathrm{~d}_{\mathrm{r}}^{3 / 2}
$$

where $\sigma_{f s}$ is the modulus of rupture of the cell-wall material

The derivation of the crushing strength for closed-cell foams parallels that for the plastic-collapse strength. Equation 5 gives the crushing stress of closed cell type elasto-brittle foams as a function of the relative density, including membrane stresses:

$$
\frac{\sigma_{\mathrm{cr}}}{\sigma_{\mathrm{fs}}}=0.2\left(\phi \mathrm{d}_{\mathrm{r}}\right)^{3 / 2}+(1-\phi) \mathrm{d}_{\mathrm{r}}
$$

These equations highlight the strong dependence of compressive strength on the relative density. Phenolic foams usually belong to the class of brittle foams. Indeed, Gibson and Ashby's model is based on the following assumptions: 
- The cells are all similar.

- The cells have a cubic geometry.

- The cells are stacked so that the vertical struts press against the middle of the struts of the neighbouring cell.

- The deformation is done by bending the struts.

- The struts have a cubic section and are made of a homogeneous material.

- The presence of fillers is not taken into consideration.

It must be pointed out that for closed cell foam Gibson and Ashby have derived equations taking into account the compression of the fluid contained in the cells and the bending of the cell edges. In practice, all of the assumptions used for Gibson and Ashby model are not verified, which can lead to a deviation from the theoretical model. The release of some of these hypotheses has been studied in various papers [68-70], showing that the choice of geometric microstructure type, alignment of struts, the deformation mechanism and the variation of the cell size can significantly influence the foam behaviour.

\subsection{Influence of the cell size}

In the literature about PF, the effect of the microstructure is often mentioned as a reason for the better mechanical behaviour of the foam material. Indeed, authors usually declared that keeping all parameters stable, and producing a smaller and more uniform cell size, will potentially improve the mechanical properties [30, 41]. Nevertheless, Gibson and Ashby's model [29] does not predict any dependence of Young's modulus or compressive strength on cell size. Moreover, there are relatively few studies reporting the mechanical behaviour of foams as a function of cell size. This is due to the difficulty of modifying the cell size without a simultaneous variation of foam density. Some studies on foams that report such results have been published for polymers foams of different natures.

For examples Liu et al. [71] studied poly(ع-caprolactone) closed cell foams with cell sizes between 80 and $170 \mu \mathrm{m}$. However, this variation in cell size is also accompanied by a variation in density. Brezny and Green [72] studied Young's modulus and mechanical strength of a cross-linked glassy carbon brittle foam made from carbonization of an open cell polymer with cell sizes ranging from 0.5 to 4.2 $\mathrm{mm}$ at constant density. The authors found that Young's modulus is independent of cell size as predicted by Gibson and Ashby's model. On the other hand, compressive and flexural strengths are inversely proportional to cell size and can be explained by a decrease in strut strength with the increasing cell size. Yu et al. [73] examined the behaviour of quasi-static compression mechanics and the deformation mechanisms of plastic closed cell aluminium foams. The effect of the cell diameter 
(2.6, 3.2 and $3.8 \mathrm{~mm})$, with a constant relative density of 0.16 , on compression and the energy absorption properties were also discussed. The result on the compressive property is clear: the maximum stress and Young's modulus increase with cell size. However, the cell wall thickness increases with the cell size. Moreover, these data are strongly impacted by size effects because the ratio between the sample size and the cell size is extremely weak. Therefore, it is difficult to draw conclusions about the effects intrinsically linked to cell size. Xu et al. [74] studied brittle Mg alloy foams with different cell sizes, fixed density and uniform structure on compressive properties. They found first that the foams with smaller average cell size possess better deformation stability when being compressed. Second, they found that decreasing the cell size leads to an improved compressive strength of the foams by sharing the load with more and smaller cells. Finally, they observed that densification strain hardly changes with the varying average cell size and fixed density. Chen et al. [75] studied the effects of cell size and cell wall thickness variations on the stiffness of closed-cell styrene-acrylonitrile foams with a density of 0.15 . They declared that both Young's modulus and compressive stress decrease with cell size variation as well as with cell wall thickness variation. These effects on moduli are independent of relative density. Moreover, for a given level of variation, the effects of cell size variation and cell wall thickness variation on the stiffness reduction are comparable.

In her PhD thesis, Gaetane [76] studied the linear and non-linear compressive behaviour of polystyrene foam and, in particular, the influence of the cell size. It was found on one hand that the Young's modulus and compressive strength increased with the cell size for a solid fraction larger than $18 \%$. On the other hand, below this solid fraction compressive properties are almost not dependent on the cell size. Moreover, the existence of heterogeneity of the cells walls of the material was observed (different degree of crosslinking, additional porosity at nanometric scale). She explained that the Young's modulus of foams is governed by the existence of two different Young's moduli, namely one characterizing the core of the wall and one characterizing a thin thickness from the surface leading to a deviation with the Gibson and Ashby model.

In summary, there is no clear experimental evidence about the effect of the cell size on foam compressive behaviour. Two types of results have been distinguished, where some are in agreement with the Gibson and Ashby model and no effect of cell size on mechanical properties is observed. Others are in disagreement and exhibit dependence of mechanical properties on the cell size that either increases or decreases the compressive properties. In the latter case, the origin of this dependence may come from the cell density, a different distribution of the cell size, the solid fraction content or heterogeneity across the structure. 
Regarding PF foams, numerous papers showing the variation of the cell size as a function of filler or chemical modification will be presented and could be compared to the variation of the mechanical properties presented previously. Moreover, different methods are usually used to influence the cell size:

- Surfactants are well known to stabilize the emulsion formed during the mixing step prior to the foaming stage through their adsorption at the droplet-phenolic resin interface, providing the interfacial tension decrease and hindering coalescence phenomenon [77].

- Fillers added in the formulation of PF may also stabilize the emulsion by Pickering $[78,79]$, modifying the foam mixture viscosity and enhancing the cell nucleation.

- The foaming agents with a higher boiling point can create smaller cells size [33].

- Process parameters such as time and speed of mixing influence the size and the number of cells [77] as well as the curing temperature but will not be discussed here.

\subsubsection{Additive route: fibres and particle reinforcement}

Although the effect of fillers on the reinforcement of PF depends on their mechanical characteristics, they may play a major role in the cell structure of the foams. As long as they are homogeneously dispersed in the phenolic resin, the fillers may ensure the formation of numerous and regular cells in the foams, according to three mechanisms. First, they act as a nucleating agent during the foaming process. Through the reduction of the critical nucleation free energy, they increase the number of bubble nuclei that are formed. Second, fillers increase the viscosity of the mixture and limit the growth and coalescence of the cells. Third, fillers contribute to the stabilization of the emulsion by the Pickering process during the mixing step and before the foaming stage. All these mechanisms provide the formation of small and uniform cells. Many studies exist in the literature, and most of them focus on particles. In most studies, the decrease of the mean cell size is connected to the increase of the compressive strength $[17,33,35,36,41,45,80,81]$. The mean cell size is noted as $<\mathrm{D}_{\text {cell }}>$.

To our knowledge, only one paper [56] reported the effect of fibres on the size of PF cells, and specifically considered cellulosic fibres (length $(L)=100-1000 \mu \mathrm{m})$. Results showed a $13 \%\left(\left\langle D_{\text {cell }}\right\rangle=\right.$ $69 \mu \mathrm{m})$ and $33 \%\left(<D_{\text {cell }}>=53 \mu \mathrm{m}\right)$ reduction of the mean cell size upon the addition of $2 \mathrm{wt} \%$ and 8 wt $\%$ of fibres, respectively.

Li et al. investigated the effect of various nanoparticles on the mean cell size of PF. Their first study [41] showed a $54 \%$ and $43 \%$ reduction in the mean cell size to $102 \mu \mathrm{m}$ and $126 \mu \mathrm{m}$ with the addition 
of 1 and $2 \mathrm{wt} \%$ of titanium nitride nanoparticles $(30 \mathrm{~nm})$, respectively. Moreover, a narrower cell size distribution was found (Figure 12).

In their second study [36], they observed a $29 \%\left(\left\langle D_{\text {cell }}\right\rangle=157 \mu \mathrm{m}\right), 54 \%\left(\left\langle D_{\text {cell }}\right\rangle=102 \mu \mathrm{m}\right)$ and $26 \%$ $\left.\left(<D_{\text {cell }}\right\rangle=165 \mu \mathrm{m}\right)$ decrease in the average cell size by incorporating $0.5 w t \%, 2 w t \%$ and $5 w t \%$ of MWNCT ( $L=10-30 \mu \mathrm{m}$, Diameter $(\mathrm{D})=10-20 \mathrm{~nm}$ ), respectively. They concluded that there is a critical amount of particles to optimize the properties. In comparison with the first study, a higher amount of MWNCT was required to obtain a similar level of improvement. Hence, TiN particles seemed to be more efficient in reducing the cells size.

The effect of MWCNT ( $L=10-30 \mu \mathrm{m}, \mathrm{D}=20-30 \mathrm{~nm}$ ) as well as modified-MWCNT was also studied by Yang et al. [35]. The addition of 0.05 wt\% pristine MWNCT, 0.05 wt\% $\mathrm{COOH}$ functionalized MWNCT and 0.05 wt\% $\mathrm{NH}_{2}$ functionalized MWNCT induced $30 \%\left(\left\langle\mathrm{D}_{\text {cell }}\right\rangle=172 \mu \mathrm{m}\right), 32 \%\left(\left\langle\mathrm{D}_{\text {cell }}\right\rangle=\right.$ $166 \mu \mathrm{m})$ and $\left.27 \%\left(<\mathrm{D}_{\text {cell }}\right\rangle=179 \mu \mathrm{m}\right)$ size reduction of the foam cells. In comparison with Li [36], Yang succeed in obtaining comparable results with a hundred times less MWCNT. Another study [17] was also conducted on the comparative effect of MWCNT and graphene on the cell size of PF. The results showed a $56 \%$ reduction of the mean cell size to $139 \mu \mathrm{m}$ with the addition of $0.5 \mathrm{wt} \%$ of MWNCT, while the size reduction increased to $73 \%\left(\left\langle\mathrm{D}_{\text {cell }}\right\rangle=85 \mu \mathrm{m}\right)$ upon the addition of $1 \mathrm{wt} \%$ of graphene.
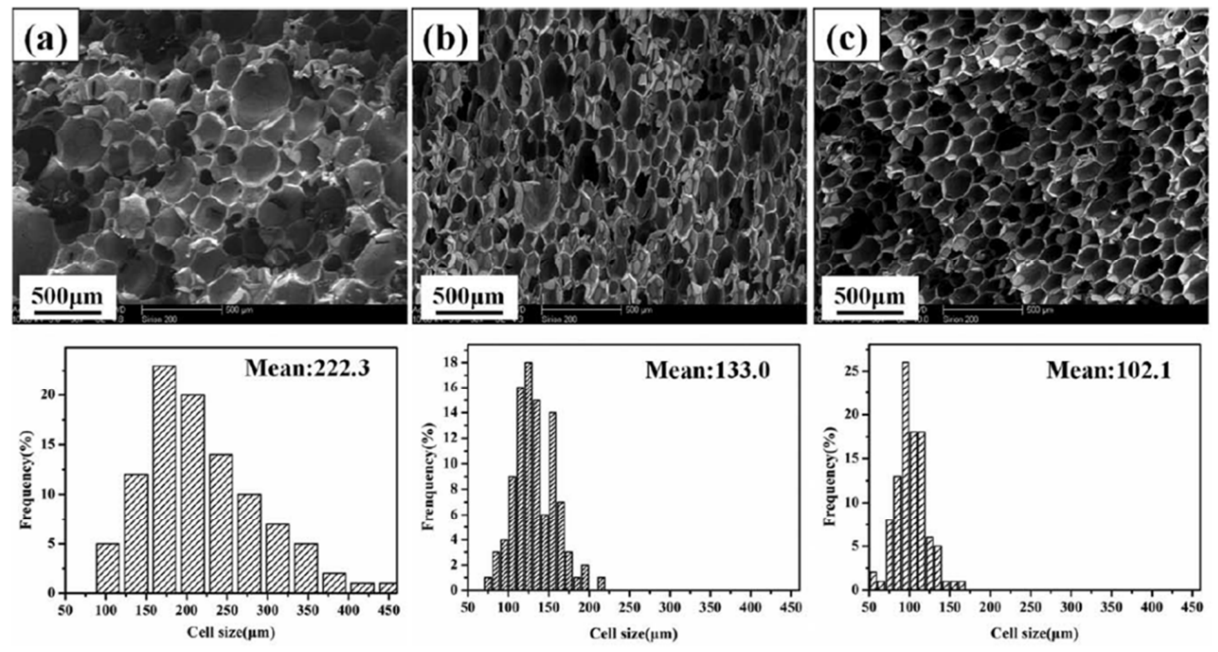

Figure 12. SEM images and the corresponding cell sizes distribution of pure phenolic foams (a), phenolic foams with 0.5 wt\% (b) and 1 wt\% (c) of titanium nitride particles [41].

Zuo et al. [58] observed a $33 \%\left(\left\langle D_{\text {cell }}\right\rangle=194 \mu \mathrm{m}\right)$ and $53 \%\left(\left\langle D_{\text {cell }}\right\rangle=138 \mu \mathrm{m}\right)$ decrease in the cell size by incorporating $10 \mathrm{wt} \%$ hollow glass beads (HGB) $(D=50-100 \mu \mathrm{m})$ or HGB modified with a silane coupling agent (Figure 13), respectively. 


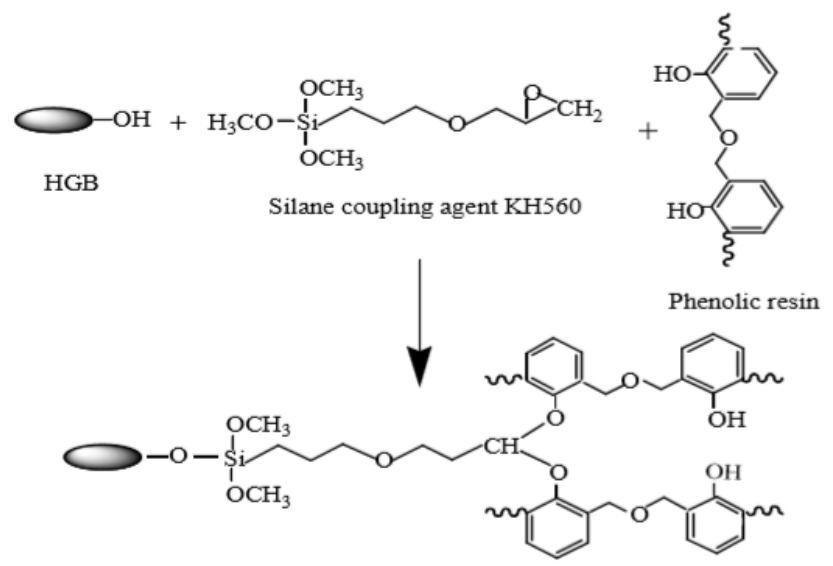

Figure 13. Schematic process of chemical reaction between HGB, coupling agent and phenolic resin [58].

The effect of clay fillers, like Cloisite ${ }^{\circledR}$ [44] and attapulgite [65], is also reported [52] [80]. The addition of $2 \%$ Cloisite $\AA 10 A$ results in a $50 \%$ decrease in the mean cell size to $50 \mu \mathrm{m}$ [52]. These results must be considered with caution since the coupled dramatic increase in the density from 237 to $314 \mathrm{~kg} \cdot \mathrm{m}^{-3}$ provides the decrease in the cell size. Another study [80] showed that the addition of 1 $w t \%$ of modified attapulgite $(D=50 \mu \mathrm{m}$ ) leads to a reduction of $24 \%$ in the mean cell size to $76 \mu \mathrm{m}$ (Figure 14).

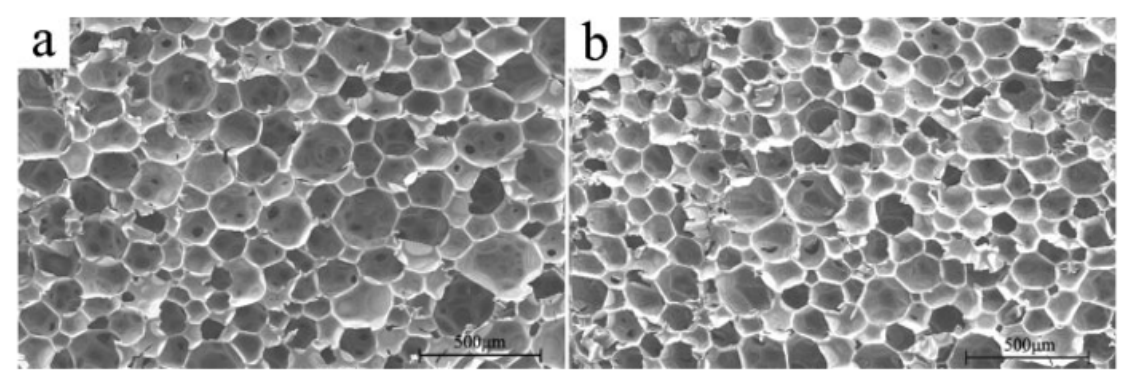

Figure 14. SEM images of (a) neat phenolic foams and (b) phenolic foams with modified $1 \mathrm{wt} \%$ attapulgite [80].

Yuan et al. [45] demonstrated a decrease in the cell size by $26 \%\left(\left\langle D_{\text {cell }}\right\rangle=72 \mu \mathrm{m}\right)$ thanks to the addition of 0.03 phr of poly(n-butyl acrylate)Silica core-shell particles $(D=180 \mathrm{~nm})$.

Contrary to the studies mentioned above, another study [82] showed a $17 \%$ increase in the compressive strength with the addition of $3 \mathrm{wt} \%$ of nitrile butadiene rubber powder (NBRP), while the mean cell size concurrently increased by $50 \%\left(\left\langle D_{\text {cell }}\right\rangle=155 \mu \mathrm{m}\right)$. This behaviour for filler reinforcement is unusual. The fillers created a more uniform distribution and a more regular shape of the cells that resulted in better mechanical properties even if the cells size increased.

Del Saz-Orozco et al. [61] were not interested in only fibre reinforcement [56], but were also interested in studying the effect of the addition of lignin $(D=1.6 \mu \mathrm{m})$ and wood flour $(D<0.15 \mathrm{~mm})$ particles. Results showed that the introduction of $8.5 \mathrm{wt} \%$ lignin particles induced a $31 \%$ reduction of 
mean cells size to $61 \mu \mathrm{m}$. On the other hand, the addition of $1.5 \mathrm{wt} \%$ wood flour particles resulted in a small reduction of the mean cell size by only $9 \%$ to $81 \mu \mathrm{m}$.

The blowing agent type also influences the PF cell size. For a constant temperature process, the higher the boiling point of the blowing agent, the lower the pressure inside the cell during the foaming step and the lower the cell size. Zhou et al. [33], observed the effect of the boiling point on the cell size of PF that were reinforced with $0.5 \mathrm{wt} \%$ of graphene oxide. Results showed that substituting $n$-pentane $\left(B_{p}=36^{\circ} \mathrm{C}\right)$ by $n$-hexane $\left(B_{p}=68^{\circ} \mathrm{C}\right)$ as blowing agent introduced at $2 \mathrm{wt} \%$ in the formulation led to a dramatic decrease of the cells size by around $79 \%\left(\left\langle D_{\text {cell }}\right\rangle=40 \mu \mathrm{m}(5)\right.$. Moreover, this Figure shows also that the cell size is higher and the cell distribution is broader for a higher amount of blowing agent.
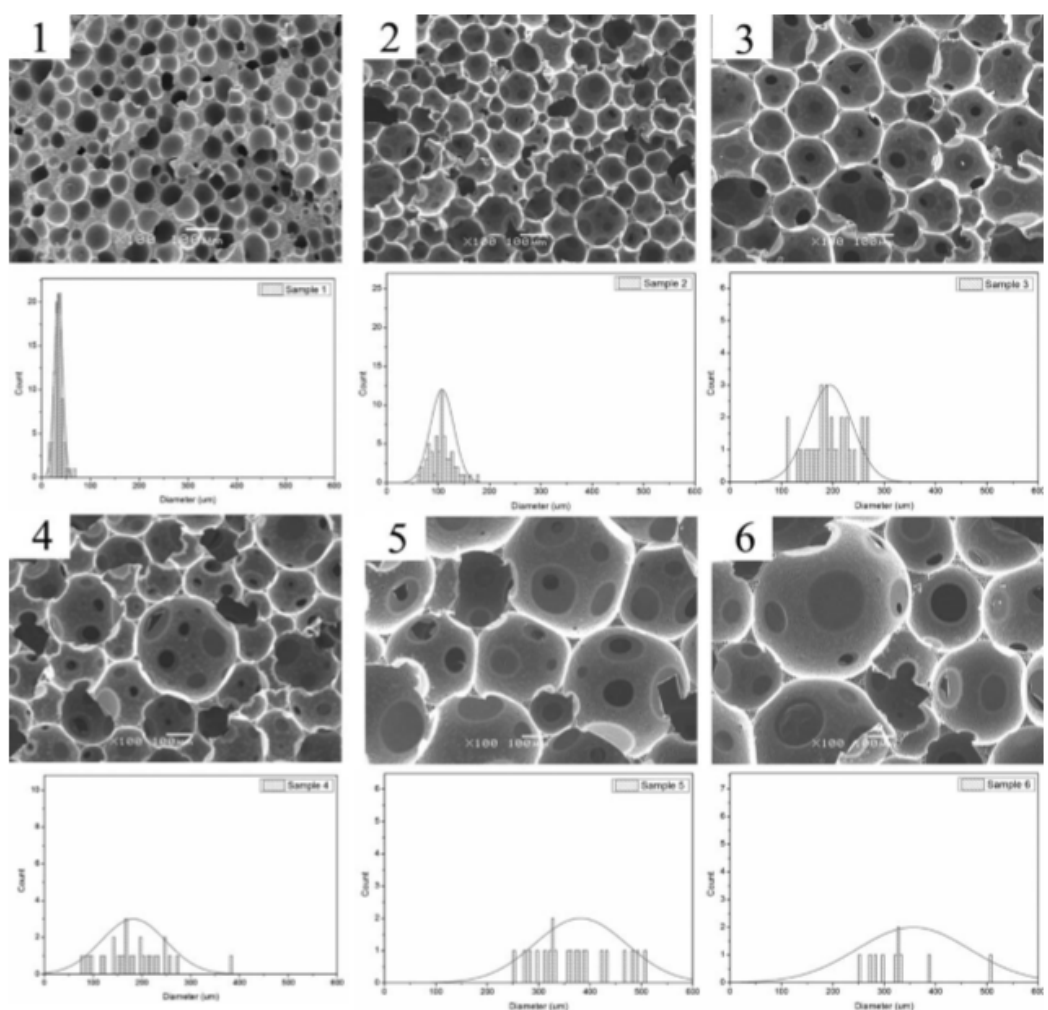

Figure 15. Structure and cell diameter distributions of phenolic foams samples using (1) 2, (2) 5 and (3) 8 wt\% of n-hexane or (4) 2 (4), (5) 5 and (6) $8 \mathrm{wt} \%$ of n-pentane as the blowing agent [33].

Table 2 summarizes the measured mean cell size for different PF reported in the literature.

Table 2. Mean cells size of several reinforced phenolic foams.

\begin{tabular}{c|c|l|l|} 
Reference & $\begin{array}{c}\text { Density } \\
{\left[\mathrm{kg} \cdot \mathrm{m}^{-3}\right]}\end{array}$ & Foam type & \multicolumn{2}{|c}{$<\mathrm{D}_{\text {cell }}>$} \\
\hline Del Saz- & 160 & PF & 79
\end{tabular}




\begin{tabular}{|c|c|c|c|c|}
\hline $\begin{array}{l}\text { Orozco et } \\
\text { al. [56] }\end{array}$ & & $\begin{array}{l}P F+2 w t \% \text { cellulose fibres } \\
P F+8 w t \% \text { cellulose fibres }\end{array}$ & $\begin{array}{l}69 \\
53\end{array}$ & $\begin{array}{l}(87) \\
(67)\end{array}$ \\
\hline $\begin{array}{l}\text { Li et al. } \\
\text { [41] }\end{array}$ & 42 & $\begin{array}{l}\mathrm{PF} \\
\mathrm{PF}+1 \mathrm{wt} \% \text { titanium nitride nanoparticles } \\
\mathrm{PF}+2 \mathrm{wt} \% \text { titanium nitride nanoparticles }\end{array}$ & $\begin{array}{l}222 \\
102 \\
126\end{array}$ & $\begin{array}{l}(100) \\
(46) \\
(57)\end{array}$ \\
\hline $\begin{array}{l}\text { Li et al. } \\
\text { [36] }\end{array}$ & 45 & $\begin{array}{l}\text { PF } \\
P F+0.5 w t \% \text { MWCNT } \\
P F+2 w t \% \text { MWCNT } \\
P F+5 w t \% \text { MWCNT }\end{array}$ & $\begin{array}{l}222 \\
157 \\
102 \\
165\end{array}$ & $\begin{array}{l}(100) \\
(71) \\
(46) \\
(74)\end{array}$ \\
\hline $\begin{array}{l}\text { Yuan et } \\
\text { al. [45] }\end{array}$ & 25 & $\begin{array}{l}\mathrm{PF} \\
\mathrm{PF}+0.03 \mathrm{phr} \text { PBA/Silica core-shell particles }\end{array}$ & $\begin{array}{l}97 \\
72\end{array}$ & $\begin{array}{l}(100) \\
(74)\end{array}$ \\
\hline $\begin{array}{l}\text { Del Saz- } \\
\text { Orozco et } \\
\text { al. [61] }\end{array}$ & 120 & $\begin{array}{l}\text { PF } \\
\text { PF + 8.5 wt\% lignin particles } \\
\text { PF + } 1.5 \text { wt } \% \text { wood flour particles }\end{array}$ & $\begin{array}{l}89 \\
61 \\
81\end{array}$ & $\begin{array}{l}(100) \\
(69) \\
(91)\end{array}$ \\
\hline $\begin{array}{l}\text { Zuo et al. } \\
\text { [58] }\end{array}$ & - & $\begin{array}{l}\text { PF } \\
\text { PF }+10 w t \% \text { hollow glass beads } \\
\text { PF }+10 w t \% \text { pretreated hollow glass beads }\end{array}$ & $\begin{array}{l}291 \\
194 \\
138\end{array}$ & $\begin{array}{l}(100) \\
(67) \\
(47)\end{array}$ \\
\hline $\begin{array}{l}\text { Song et al. } \\
\text { [17] }\end{array}$ & $\begin{array}{l}66 \\
50 \\
50\end{array}$ & $\begin{array}{l}\text { PF } \\
P F+0.5 w t \% \text { MWCNT } \\
P F+1 w t \% \text { graphene }\end{array}$ & $\begin{array}{l}318 \\
139 \\
85\end{array}$ & $\begin{array}{l}(100) \\
(44) \\
(27)\end{array}$ \\
\hline $\begin{array}{l}\text { Zhou et } \\
\text { al. [33] }\end{array}$ & 80 & $\begin{array}{l}\text { PF + } 0.5 \text { wt\% GO (FA: } 2 \text { wt\% n-pentane) } \\
P F+0.5 w t \% \text { GO (FA: } 2 \text { wt\% n-hexane) } \\
P F+0.5 w t \% \text { GO (FA: } 8 w t \% \text { n-hexane) }\end{array}$ & $\begin{array}{l}190 \\
40 \\
190\end{array}$ & $\begin{array}{l}(100) \\
(21) \\
(100)\end{array}$ \\
\hline $\begin{array}{l}\text { Yang et al. } \\
\text { [35] }\end{array}$ & 50 & $\begin{array}{l}P F \\
P F+0.05 w t \% \text { pristine MWNCT } \\
P F+0.01 w t \% \text { MWCNT-COOH } \\
P F+0.05 w t \% \text { MWCNT-COOH } \\
P F+0.05 w t \% \text { MWCNT-NH2 }\end{array}$ & $\begin{array}{l}244 \\
172 \\
217 \\
166 \\
179\end{array}$ & $\begin{array}{l}(100) \\
(70) \\
(89) \\
(68) \\
(73)\end{array}$ \\
\hline $\begin{array}{l}\text { Li et al. } \\
\text { [82] }\end{array}$ & 55 & $\begin{array}{l}P F \\
P F+3 w t \% N B R P\end{array}$ & $\begin{array}{l}103 \\
155\end{array}$ & $\begin{array}{l}(100) \\
(150)\end{array}$ \\
\hline $\begin{array}{l}\text { Zhuang et } \\
\text { al. [80] }\end{array}$ & 75 & $\begin{array}{l}\text { PF } \\
\text { PF + } 1 \text { wt } \% \text { modified attapulgite }\end{array}$ & $\begin{array}{l}277 \\
211\end{array}$ & $\begin{array}{l}(100) \\
(76)\end{array}$ \\
\hline Rangari et & 237 & $\mathrm{PF}$ & 100 & (100) \\
\hline
\end{tabular}




\section{() Changes relative to the reference sample (100\%)}

\subsubsection{Reactive route}

Chemical modification of phenolic resins by PU or PEG is often used to increase the compressive and flexural strength and decrease the friability. Nevertheless, only two authors reported that the chemical modification may also influence the size, shape and uniformity of the PF cells. This is the case because the modifier can act as a surfactant or modify the resin viscosity.

Upon the addition of 3 and $7 \mathrm{wt} \%$ castor oil based polyurethane prepolymer (COPUP) [48], the PF cell size increased up to $59 \%\left(\left\langle D_{\text {cell }}\right\rangle=173 \mu \mathrm{m}\right)$ and $18 \%\left(\left\langle D_{\text {cell }}\right\rangle=129 \mu \mathrm{m}\right)$, respectively. This cell size increase was in accordance with the decrease of the compressive strength observed by the authors.

Liu et al. [12] obtained similar results by comparing the evolution of the mean size and the improvements of the compressive strength, flexural strength and friability with the addition of various molar mass modified PEGs. Their morphological study showed that the mean cell size increased by $66 \%\left(\left\langle D_{\text {cell }}\right\rangle=642 \mu \mathrm{m}\right), 17 \%\left(\left\langle D_{\text {cell }}\right\rangle=450 \mu \mathrm{m}\right)$ and $17 \%$ with the addition of $4.5 \mathrm{wt} \%$ of boron-modified PEG 200, 400 and 600, respectively. The lowest compression enhancement was obtained with the modified PEG 200. However, SEM images show that the pure PF cells were not very uniform and the shape was ellipsoid-like. In comparison, the distribution of the cells of PF modified with PEG 200 and 400 PF was much more uniform with a hexagonal shape, which is known to be stable [13]. Authors attributed the change in the structure to the modified PEG that acts as a surfactant and increases the viscosity. Nevertheless, they mentioned that for the case of PEG-BAE 600 , the distribution of the cell sizes was still not uniform because its viscosity was too high and made the blowing agent difficult to disperse in the phenolic resins. This highlights the importance of cell shape and uniformity more than the cell size. The cell sizes $(\mu \mathrm{m})$ for the above reported results of modified PF are listed in Table 3.

Table 3. Mean cells size of several modified phenolic foams.

\begin{tabular}{c|c|l|ll} 
Reference & $\begin{array}{c}\text { Density } \\
{\left[\mathrm{kg} \cdot \mathrm{m}^{-3}\right]}\end{array}$ & Foam type & $\begin{array}{l}\left.<\mathrm{D}_{\text {cell }}\right\rangle \\
{[\mu \mathrm{m}]}\end{array}$ \\
\hline $\begin{array}{c}\text { Bo et al. } \\
{[48]}\end{array}$ & 38 & $\mathrm{PF}$ & 109 & $(100)$ \\
& & $\mathrm{PF}+3 \%$ castor oil-based PU prepolymer & 173 & $(159)$ \\
\hline
\end{tabular}




\begin{tabular}{|c|c|c|c|c|}
\hline \multirow{4}{*}{$\begin{array}{c}\text { Liu et al. } \\
\text { [12] }\end{array}$} & \multirow{4}{*}{25} & PF & 386 & (100) \\
\hline & & $P F+4.5 w t \%$ PEG 200 BAE & 642 & (166) \\
\hline & & $P F+4.5 w t \%$ PEG 400 BAE & 450 & (117) \\
\hline & & $P F+4.5 w t \%$ PEG $600 \mathrm{BAE}$ & 450 & (117) \\
\hline
\end{tabular}

() Changes relative to the reference sample (100\%)

To conclude, the PF cell size may be controlled by the mixture viscosity, the surfactant content, the blowing agent nature or the nucleating agent. Fillers may act on the mean PF cell size through different mechanisms. The increase of the viscosity due to the added particles will limit the cell growth, cell coalescence, reduction of the cell wall thickness and hence the collapse of the cells. The particles behave as nucleating agents and favour the development of more numerous small cells. Moreover, particles can stabilize the cell by forming a Pickering emulsion. For these different reasons, particles have the potential to reduce the cell size and improve the cell shape and uniformity.

Moreover, the blowing agent type also influences the PF cell size. At a fixed curing temperature, a blowing agent with a higher boiling point develops a lower pressure inside the cell during the foaming step. Thus, the obtained cells are smaller and the cell distribution is narrower. Only two papers reported the indirect effect of the chemical modification of PF on the mean cell size. Both described the increase of the mean cell size by the introduction of PEG and polyurethane in the phenolic resin backbone.

Although no explicit correlation between the cell size with the mechanical properties have been determined, researchers have tried to correlate them. However, they have observed that the cell shape and cell distribution also play a role. Moreover, other parameters are also known to be relevant, such as the strut shape, length and heterogeneity. If these have not been studied, one can incorrectly interpret the effect of the cell size. Therefore, for the rest of this review, the effect of the cell size will no longer be discussed.

\subsection{Compressive strength}

The compressive strength represents the resistance of a material against compression or its capacity to withstand loads tending to reduce size before collapsing. As a consequence, it is one of the main properties of materials used for shock absorbing applications. According to the ASTM D 1621- 
Standard Test Method for Compressive Properties of Rigid Cellular Plastics, the compressive strength is defined as the stress at the yield point if it occurs before $10 \%$ of deformation or, in the absence of such a yield point, the stress at $10 \%$ of deformation.

The compressive strength depends on the toughness of the cell wall although density plays the crucial role in compressive strength [29]. Hence, different methods have been developed to improve the compressive properties of PF without modifying the density. Three main categories are fibre reinforcement, addition of inert particles and chemical modification [9]. Fibre and particle reinforcement are mainly provided by their high stiffness in comparison with the phenolic matrix as long as their compatibility with the phenolic resin matrix is adequate. The first challenge of this approach is to achieve a uniform dispersion of the fillers in the reactive system during the foam production [9]. Indeed, the addition of particles and fibres in the formulation induces a significant increase in the foaming mixture viscosity, which may cause some problems during the mixing and expansion of the foam [9]. Moreover, the presence of fillers usually increases the density of foam. The chemical modification route is particularly attractive since it relies on the chemical modification of the resin backbone. It is typically based on the introduction of flexible chains into the rigid backbone of the phenolic resin, such as polyurethane [46, 83], epoxy [49] or polyethylene glycol [12, 59]. Unfortunately, this way may undermine the flame, smoke and toxicity requirements $[12,13]$. Finally, it can be also possible to improve the compressive properties through chemical modification and fibre or particles reinforcement [47].

\subsubsection{Additive route: fibre reinforcement}

The most influential parameters involved in the reinforcement of PF compressive properties by fibres are the stiffness of the fibres, their concentration in the PF, compatibility with the resin matrix or orientation in the foams.

The stiffness of the fibres is one of the most important parameters. This was demonstrated by Desai et al. [34] and Shen et al. [10], who reported that significant reinforcement results were obtained with stiff fibres. They compared the effect of stiff glass ( $E \approx 80 \mathrm{GPa})$ and aramid Nomex ${ }^{\circledR}$ fibres (E $\approx$ $20 \mathrm{GPa}$ ) with a length of $6.4 \mathrm{~mm}$ and a diameter of $12 \mu \mathrm{m}$ on the PF compressive properties for densities around 0.2 [34] and 0.08 [10]. In the Desai study [34], the compressive strength increased by $275 \%$ after adding 5 wt $\%$ of glass fibres and by $36 \%$ after adding the same amount of aramid fibres (Figure 16a). A combination of fibres led to results comparable to the ones obtained for glass fibres reinforcement (Figure 16b). Hence, fibre stiffness plays a crucial role in the foam reinforcement. 
Indeed, stiff glass fibres are highly orientated along the foaming direction [10, 34, 84] inducing a highly significant enhancement in that direction whereas almost no evolution is observed in the perpendicular direction. In comparison, aramid fibres are randomly distributed and thus, favour the isotropic character of the foam. Similar results were reported by Yuan et al. with glass fibres ( $L: 6.5$ $\mathrm{mm}, \mathrm{D}: 10 \mu \mathrm{m})$ [47]. An additional improvement of the compressive strength equal to $14 \%$ was observed when 3 wt\% of a phosphorus-containing polyurethane prepolymer (DOPU) (Figure 17) was added, but the density concurrently slightly increased.
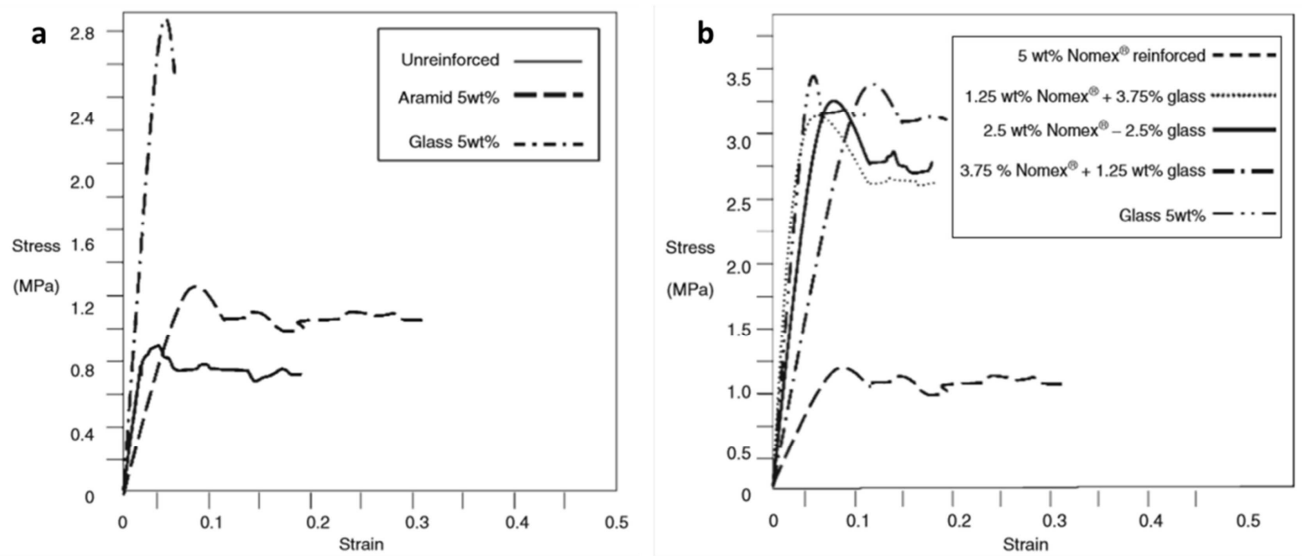

Figure 16. Typical compression stress-strain curves of modified phenolic foams with (a) aramid or glass fibres and (b) with a combination of glass and aramid fibre [34].
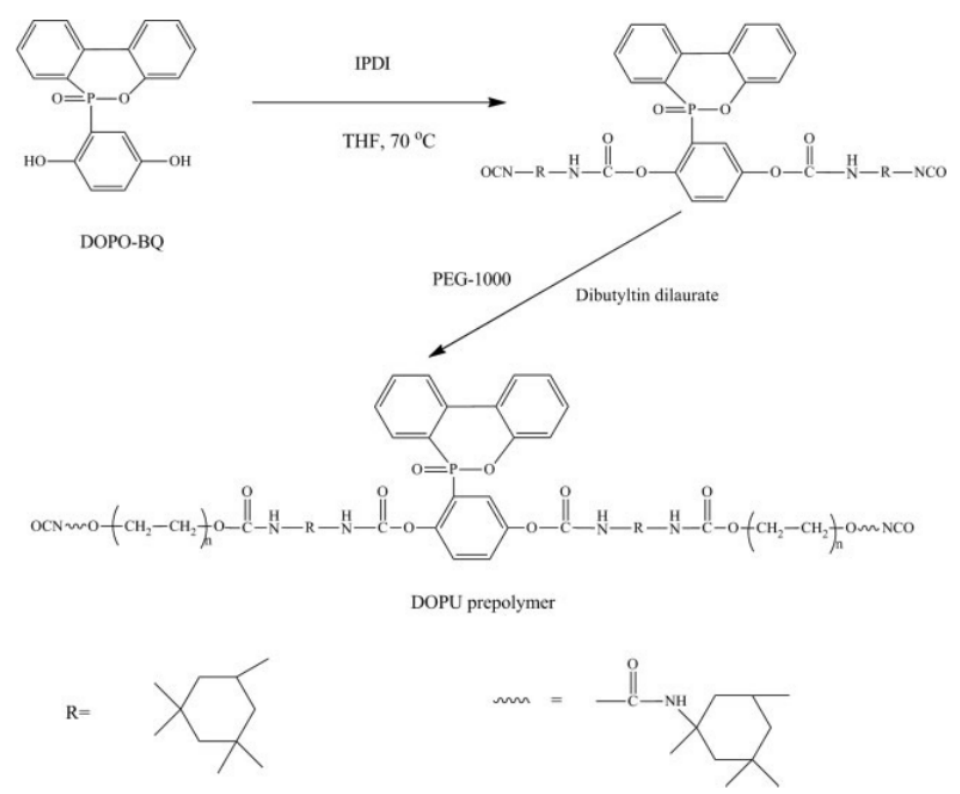

Figure 17. Synthesis route to phosphorus-containing polyurethane prepolymer, DOPU [47].

Another key factor in the reinforcement offered by the fibres is the compatibility between them and the phenolic resin. Yu et al [57] highlighted the influence of the interfacial adhesion between the 
fibres and the phenolic resin by modifying the surface of aramid fibres $(L: 3 \mathrm{~mm}, \mathrm{D}: 12 \mu \mathrm{m})$ even though they already possess a good affinity with the resin. The treatment of the fibres by sodium hydride and dimethylsulfoxide, according to the authors, produced more active sites and increased the quantity of polar functions that can react with the polar resin matrix. No more information on the nature or the quantity of the created functions was given by the authors. While the compressive strength increased by about 52\% after adding 6 wt $\%$ of non-modified aramid fibres, the improvement of $67 \%$ was obtained for modified aramid fibres in the same amount, which supported the efficiency of the surface modification. In opposition, Ma et al. [85] have reported a that the addition of 4 wt\% modified wood fibres decreased the compressive strength by $36 \%$.

Besides the type and the surface of the fibres, the suitable amount of fibres to be added into the foam mixture must also be considered. On one hand, an amount that is too high may cause an increase in the foam mixture viscosity and hence disturb the mixing and foaming stages. On the other hand, the improvement is reduced and can even dramatically decrease the PF compressive strength above a certain critical fibre concentration. Del Saz-Orozco et al. [56] reported that the addition of 2 wt $\%$ of cellulose fibres (length $=100-1000 \mu \mathrm{m}$ ) increased in the compressive strength by $18 \%$, whereas adding up to $8 w t \%$ of the fibres caused a 19\% reduction in the compressive strength (Figure 18). Shen et al. [10] reported similar results for aramid fibres while no limit was observed for glass fibres up to $10 \mathrm{wt} \%$. The analysis of the literature indicates that the fibre reinforcement of PF with cellulose fibres is less efficient than with aramid or glass fibres, in accordance with their respective stiffness.

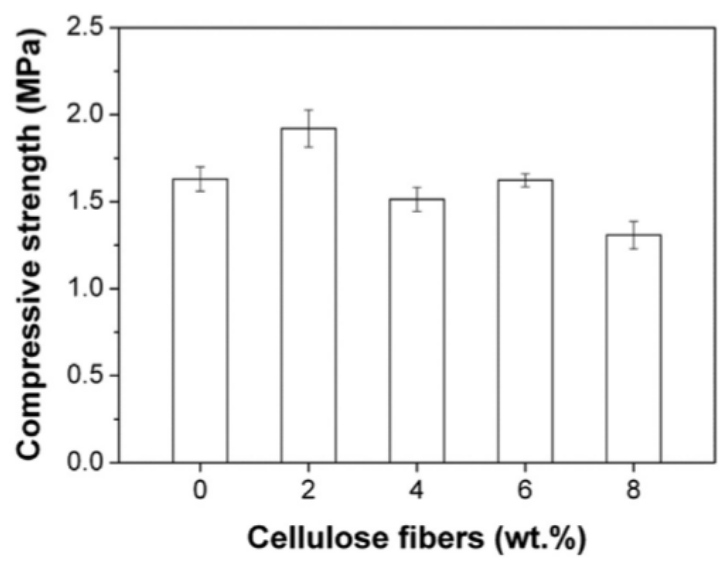

Figure 18. Compressive strength for PF and PF modified with 2, 4, 6 and 8 wt\%. of cellulose fibres [56].

Table 4 summarizes the published results regarding compressive strength of fibre-reinforced PF.

To conclude, among the fibres, glass fibres are the most efficient to enhance compressive strength due to its high stiffness. Nevertheless, these fibres are oriented mainly along the foaming direction 
and lead to a higher improvement of compressive strength in that direction. Thus, the foam anisotropy is accentuated or created.

Table 4. Compressive strength of several fibre-reinforced phenolic foams.

\begin{tabular}{|c|c|c|c|c|}
\hline Reference & $\begin{array}{l}\text { Density } \\
{\left[\mathrm{kg} \cdot \mathrm{m}^{-3}\right]}\end{array}$ & Foam type & \multicolumn{2}{|c|}{$\begin{array}{l}\text { Compressive strength } \\
\text { [MPa] }\end{array}$} \\
\hline $\begin{array}{l}\text { Del Saz- } \\
\text { Orozco et } \\
\text { al. [56] }\end{array}$ & 160 & $\begin{array}{l}\text { PF } \\
P F+2 w t \% \text { cellulose fibres } \\
P F+8 w t \% \text { cellulose fibres }\end{array}$ & $\begin{array}{l}1.63 \\
1.92 \\
1.32\end{array}$ & $\begin{array}{l}(100) \\
(118) \\
(81)\end{array}$ \\
\hline $\begin{array}{l}\text { Ma et al. } \\
\text { [85] }\end{array}$ & - & $\begin{array}{l}P F \\
P F+4 w t \% \text { modified wood fibres }\end{array}$ & $\begin{array}{l}0.110 \\
0.07\end{array}$ & $\begin{array}{l}(100) \\
(64)\end{array}$ \\
\hline $\begin{array}{l}\text { Yu et al. } \\
\text { [57] }\end{array}$ & 70 & $\begin{array}{l}P F \\
P F+6 w t \% \text { modified aramid fibres } \\
P F+6 w t \% \text { non-modified aramid fibres }\end{array}$ & $\begin{array}{l}0.21 \\
0.35 \\
0.32\end{array}$ & $\begin{array}{l}(100) \\
(167) \\
(152)\end{array}$ \\
\hline $\begin{array}{l}\text { Yuan et } \\
\text { al. [47] }\end{array}$ & $\begin{array}{l}48 \\
48 \\
53\end{array}$ & $\begin{array}{l}P F \\
P F+0.5 w t \% \text { glass fibres } \\
P F+0.5 w t \% \text { glass fibres }+3 w t \% \text { DOPU }\end{array}$ & $\begin{array}{l}0.16 \\
0.19 \\
0.21\end{array}$ & $\begin{array}{l}(100) \\
(124) \\
(138)\end{array}$ \\
\hline $\begin{array}{l}\text { Desai et } \\
\text { al. [40] }\end{array}$ & $\begin{array}{l}224 \\
200 \\
208\end{array}$ & $\begin{array}{l}P F \\
P F+5 \text { wt } \% \text { aramid fibres } \\
P F+5 \text { wt } \% \text { glass fibres }\end{array}$ & $\begin{array}{l}0.92 \\
1.25 \\
3.45\end{array}$ & $\begin{array}{l}(100) \\
(136) \\
(375)\end{array}$ \\
\hline $\begin{array}{l}\text { Shen et } \\
\text { al. [10] }\end{array}$ & 80 & $\begin{array}{l}P F \\
P F+5 w t \% \text { aramid fibres } \\
P F+10 w t \% \text { aramid fibres } \\
P F+5 w t \% \text { glass fibres } \\
P F+10 w t \% \text { glass fibres }\end{array}$ & $\begin{array}{l}0.76 \\
0.90 \\
0.71 \\
0.90 \\
1.10\end{array}$ & $\begin{array}{l}(100) \\
(118) \\
(93) \\
(118) \\
(145)\end{array}$ \\
\hline
\end{tabular}

\section{() Changes relative to the reference sample (100\%)}

\subsubsection{Additive route: Particle reinforcement}

Numerous types of micro- or nanoparticles have also been tested to increase the compressive strength of the PF. The examination of the published results revealed the influence of significant parameters. Particle reinforcement is based on the same mechanisms as for fibres, i.e. their stiffness [86], concentration in the PF [58, 87], compatibility with the resin matrix $[31,35]$ and orientation in the foams [86] are critical. Nevertheless, the particles used are mainly at microscale and sometimes 
the nanoscale whereas fibres typically measure a few millimetres with a diameter of around ten micrometres. Hence, they generally offer a lower aspect ratio than the fibres, making the foam less anisotropic. Moreover, as mentioned before, particles may act as nucleating agents and cause an increase in the cell density of the foam and result in cells with a more uniform distribution and finer size $[30,41]$. Attention also has to be paid to the mixture viscosity because the addition of particles increases it. This can be beneficial for the final microstructure, but if the increase is too high, it can impede the foam expansion [45]. Compared with fibres, the increase in viscosity is less problematic during the mixing stage because the particles have a smaller aspect ratio. Finally the particle incorporation can lead to an increase in the final foam density if the initial parameters are not well controlled [52]. A large variety of particles are listed in the literature, such as MWCNT [17, 36, 88], HGB [58], mineral particles [51, 52], non-modified and modified graphene oxide particles [30, 33, 87], natural particles [61] and polyurethane foams scraps [43].

Yu et al. [89] studied the reinforcement of PF by introducing 0.8 wt\% of expandable and expanded which improve the compressive strength by $70 \%$ and $80 \%$, respectively. Li et al. studied the introduction of titanium nitride (TiN) nanoparticles $(30 \mathrm{~nm}$ ) [41], silica solution (D = $25 \mathrm{~nm}$ ) [31] or MWCNT ( $L=10-30 \mu \mathrm{m}, D 10-20 \mathrm{~nm}$ ) in the formulation [36]. The maximum value for the compressive strength was obtained with the following amounts: 1 wt\% of TiN nanoparticles, $2 \mathrm{wt} \%$ of silica solution and $2 \mathrm{wt} \%$ of MWCNT, corresponding to an improvement of $12 \%, 47 \%$ and $240 \%$, respectively. For the TiN nanoparticles [41] and MWCNT [36], the authors attributed the reinforcement to the stiffness of the particles as well as to their nucleating effect. These factors resulted in a more uniform cell morphology, lower mean cell size and higher cell density. For the silica solution [31], the reinforcement was attributed to the chemical crosslink bonding, i.e. condensation reaction between silanols groups of the silica and the $\mathrm{OH}$ groups of the phenolic resin. Moreover, MWCNT have been reported as fillers in PF [17, 35] [36], and all the studies point out the increase of the compressive strength with the addition of small amount of MWCNT. Song et al. [17] observed a $27 \%$ improvement in the compressive strength with the addition of $0.5 \mathrm{wt} \%$ MWCNT ( $L=$ $5 \mu \mathrm{m}, \mathrm{D}=6-9 \mathrm{~nm}$ ). The functionalization of MWCNT provides a synergistic enhancement of the compressive strength as noticed by Yang et al. [35] A 37\% increase in the compressive strength was first obtained with only 0.05 wt\% of pristine MWCNT $(L=10-30 \mu \mathrm{m}, D=20-30 \mathrm{~nm})$ due to a more uniform microstructure, and $43 \%$ with 0.05 wt\% of MWCNT functionalized $\mathrm{COOH}$ (Figure 19) due to better interaction between particles and phenolic matrix. The results are less interesting with $\mathrm{NH}_{2}$ functionalized MWCNT compared to $\mathrm{COOH}$ since the compressive strength was increased by only 34 $\%$. The results clearly demonstrate the importance of chemical adhesion between the fillers and the 
phenolic resin. Moreover, the good dispersion of modified MWCNT reduces the stress concentration and improves the stress transfer efficiency $[17,35][36]$.

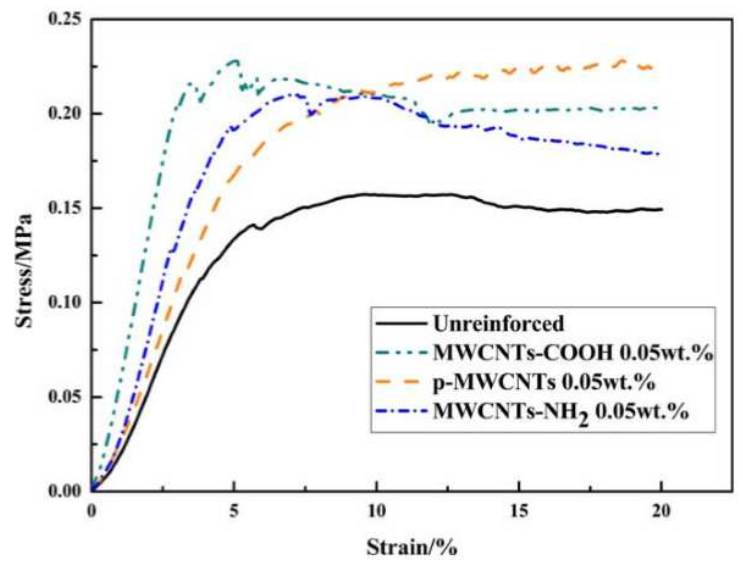

Figure 19. Typical compressive stress-strain curves of phenolic foams filled with MWCNT in different type [35].

The addition of HGB $(50-100 \mu \mathrm{m})$ can help to stop the propagation of the cracks and strengthen the foams because they are located at the junction of the cells [58]. The effect of this kind of filler surface modification is the same as that observed for MWCNT [58]. Zuo et al. [58] reported a critical amount of HGB (10 wt\%) beyond which the compressive strength decreases and explained this result by the occurrence of defects in the cell structure (Figure 20). Note, however, that there is an important oversight in their work since no information about the final foam density is mentioned.

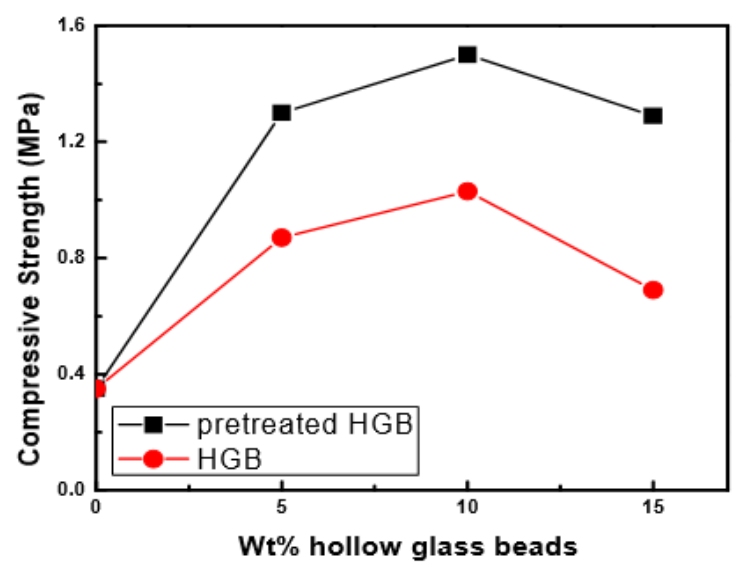

Figure 20. Compressive strength of phenolic foams with different content of HGB and HGB modified with a silane coupling agent [58].

Clay reinforcement has also been shown to increase the compressive strength of PF [52] [80]. Besides the classical efficacy to increase the cell density and reduce the cell size, this type of particle seems to also increase the polymerization degree [52] [80]. Zhuang et al. [80] reported a $17 \%$ increase in the compressive strength by adding $1 \mathrm{wt} \%$ of attapulgite $(D=50 \mu \mathrm{m})$ modified with hexadecyl trimethyl ammonium bromide (HTAB-ATP) due to the increase in polymerization degree given by the 
nanoparticles. Another study [52], indicated that the addition of $2 \%$ of Cloisite $\AA$ 10A enabled an increase of $142 \%$ in the compressive strength. It should be noted that the density also dramatically increased from 237 to $314 \mathrm{~kg} . \mathrm{m}^{-3}$. Therefore, it appears difficult to draw conclusions about the real effect of this filler since the final density is quite higher than the reference one.

Some authors highlighted the synergistic effect of the concurrent use of various fillers [30, 87], especially due to good interaction between particles and the phenolic resin, their nucleation effect and high aspect ratios. Li et al. [87] noticed the increase in the compressive strength of $21 \%$ and $10 \%$ with the addition of graphene oxide sheets (dimensions unknown) and silica ( $D=20 \mathrm{~nm}$ ) respectively, whereas the enhancement was about $36 \%$ with the silica-graphene oxide (SGO) hybrid particles (Figure 21). In another article [30], the authors compared the effect of another hybrid, namely the alpha zirconium phosphate/graphene oxide hybrid (ZGO) with graphene oxide and the alpha zirconium phosphate $(\alpha-Z r P)$. Results revealed an increase in the compressive strength of $21 \%$ and $12 \%$ with the addition of $\mathrm{GO}$ and $\alpha$-ZrP, respectively, and a more significant increase of $38 \%$ with the ZGO blend. Results revealed an increase in the compressive strength of $21 \%$ and $12 \%$ with the addition of GO and $\alpha-Z r P$, respectively, and a more significant increase of $38 \%$ with the ZGO blend. More recently, different authors have also studied modified GO, magnesium amino-tris(methylenephosphonate) reduced graphene oxide hybrid [90] and Graphene oxide immobilized with layered double hydroxide [92] respectively. They observed an improvement of the compressive flexural strengths properties of the phenolic foams

Zhou et al. [33] introduced graphene oxide in PF, but the results showed no significant change in compressive strength.
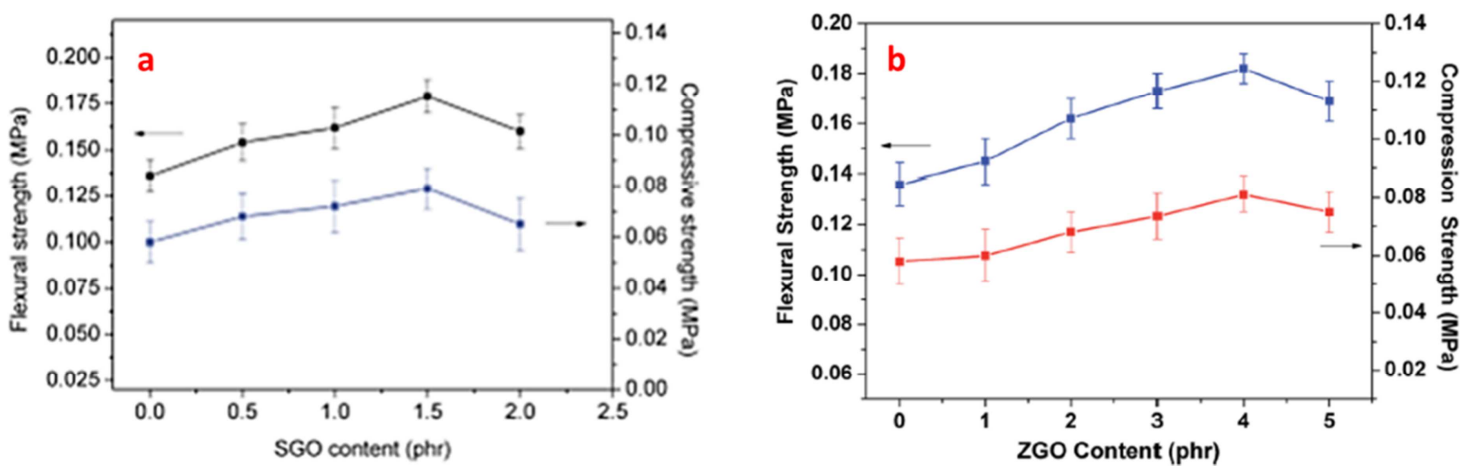

Figure 21. Effect of (a) SGO and (b) ZGO content on flexural and compressive strength [30, 87].

Natural particles have proved to develop favourable interactions with the phenolic resin, leading to the increase of the compressive properties [61]. Nevertheless, various amounts are required, according to the nature of the particles. Del Saz-Orozco et al. [61] investigated the effects of the 
addition of lignin $(D=1.6 \mu \mathrm{m})$ and wood flour $(D<0.15 \mathrm{~mm})$ particles. The addition of $8.5 \mathrm{wt} \%$ of lignin particles improved the compressive strength by $74 \%$ while the addition of $1.5 \mathrm{wt} \%$ of wood flour particles resulted in a reinforcement of $54 \%$. The enhancement is comparable to those found for synthetic particles, and unfortunately, the authors did not investigate the fire-retardant properties that could potentially be deteriorated with natural particles.

The addition of organic particles increases the compressive strength of the PF since they improve the stress dissipation. Li et al. reported the reinforcement of $17 \%$ of compressive strength thanks to 3 wt\% of nitrile butadiene rubber powder (NBRP) $[82,93]$. The NBRP is crosslinked to the phenolic resin (Figure 22), thus help to dissipate stress.

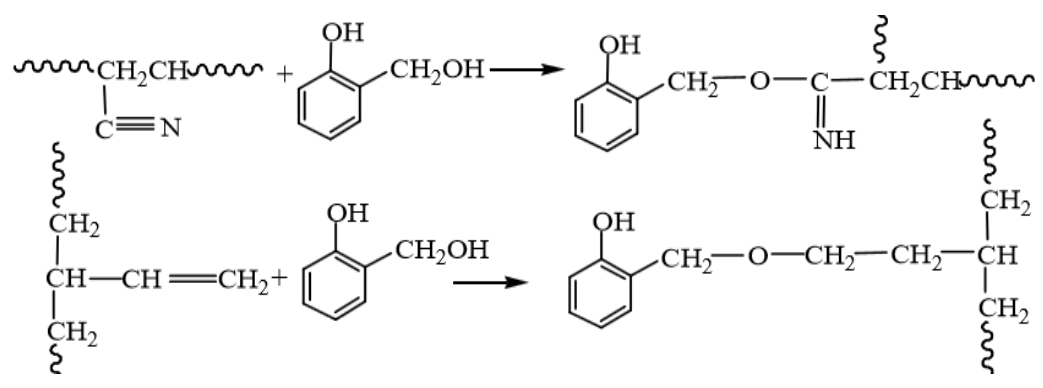

Figure 22. Possible crosslinking mechanism between phenolic resin and NBRP [82].

As for the inorganic fillers, the polymeric ones added in the PF formulation increase the compressive strength of the PF through the good cohesion between the particles and matrix and a better uniformity of the cells. Yang et al. [43] observed that the incorporation of $5 \mathrm{wt} \%$ of polyurethane foam scraps particles $(D=80-150 \mu \mathrm{m})$ increases the compressive strength by $12 \%$. The same observations were reported with the addition of $0.05 \mathrm{phr}$ of poly(n-butyl acrylate)/Silica (PBA/Silica) core-shell particles $(D=180 \mathrm{~nm}$ ) [45], which led to a $45 \%$ improvement of the compressive strength.

Ma et al. [38] dedicated their work to improving the flame retardancy and observed the effect of zinc oxide $(\mathrm{ZnO})$ in combination with a flame retardant system composed of ammonium polyphosphate (15 wt\%) and pentaerythritol (5 wt\%) on the mechanical properties of PF. In contrast, they showed that the addition of zinc oxide $(\mathrm{ZnO})$ with flame retardant system leads to a reduction in the compressive strength due to too many additives being incorporated into the formulation.

In summary, HGB has been shown to be more efficient, but no information is given about the final foam density. The MWNCT show a very good improvement in the compressive strength even with the incorporation of an extremely small number of particles $(<0.05 w t \%)$. Natural particles, that are less expensive than MWNCT, also exhibit a good reinforcement but may influence the fire properties. 
The ZGO and SGO hybrids improve the compressive strength more moderately but exhibit a synergistic effect. Moreover, as will be shown, they improve all the properties studied in this review. The effect of the mechanical properties of particles has not been discussed here as they are generally not reported by the authors as for fibres. The improved properties over the phenolic matrix generally lead to an enhancement of the compressive strength as long as there is a good interaction between the particles and the phenolic matrix. Table 5 summarizes papers on PF reinforced with particles regarding the compressive strength property.

Table 5. Compressive strength of several reinforced phenolic foams with particles.

\begin{tabular}{|c|c|c|c|c|}
\hline Reference & $\begin{array}{l}\text { Density } \\
{\left[\mathrm{kg} \cdot \mathrm{m}^{-3}\right]}\end{array}$ & Foam type & \multicolumn{2}{|c|}{$\begin{array}{l}\text { Compressive strength } \\
\text { [MPa] }\end{array}$} \\
\hline $\begin{array}{l}\text { Li et al. } \\
\text { [30] }\end{array}$ & 16 & $\begin{array}{l}\text { PF } \\
P F+4 p h r Z G O \\
P F+4 p h r G O \\
P F+4 p h r \alpha-Z r P\end{array}$ & $\begin{array}{l}0.060 \\
0.070 \\
0.065 \\
0.080\end{array}$ & $\begin{array}{l}(100) \\
(117) \\
(108) \\
(133)\end{array}$ \\
\hline $\begin{array}{l}\text { Li et al. } \\
\text { [41] }\end{array}$ & 42 & $\begin{array}{l}\text { PF } \\
\text { PF + } 1 \text { wt } \% \text { TiN nanoparticles }\end{array}$ & $\begin{array}{l}0.099 \\
0.111\end{array}$ & $\begin{array}{l}(100) \\
(112)\end{array}$ \\
\hline $\begin{array}{l}\text { Li et al. } \\
\text { [36] }\end{array}$ & 45 & $\begin{array}{l}P F \\
P F+0.5 w t \% M W C N T \\
P F+2 w t \% M W C N T \\
P F+5 w t \% M W C N T\end{array}$ & $\begin{array}{l}0.10 \\
0.24 \\
0.34 \\
0.17\end{array}$ & $\begin{array}{l}(100) \\
(240) \\
(340) \\
(175)\end{array}$ \\
\hline $\begin{array}{l}\text { Li et al. } \\
\text { [87] }\end{array}$ & 16 & $\begin{array}{l}\mathrm{PF} \\
\mathrm{PF}+1.5 \mathrm{phr} \mathrm{SGO} \\
\mathrm{PF}+0.5 \mathrm{phr} \mathrm{SiO}_{2} \\
\mathrm{PF}+0.5 \mathrm{phr} \mathrm{GO}\end{array}$ & $\begin{array}{l}0.058 \\
0.079 \\
0.064 \\
0.070\end{array}$ & $\begin{array}{l}(100) \\
(136) \\
(110) \\
(121)\end{array}$ \\
\hline $\begin{array}{l}\text { Li et al. } \\
\text { [31] }\end{array}$ & 45 & $\begin{array}{l}\mathrm{PF} \\
\mathrm{PF}+2 \mathrm{wt} \% \text { Silica }\end{array}$ & $\begin{array}{l}0.19 \\
0.28\end{array}$ & $\begin{array}{l}(100) \\
(147)\end{array}$ \\
\hline $\begin{array}{l}\text { Liu et al. } \\
\text { [90] }\end{array}$ & - & $\begin{array}{l}\text { PF } \\
\mathrm{PF}+4 \mathrm{phr} \mathrm{Mg}-\mathrm{rGO}\end{array}$ & $\begin{array}{l}0.060 \\
0.088\end{array}$ & $\begin{array}{l}(100) \\
(147)\end{array}$ \\
\hline $\begin{array}{c}\text { Luo et al. } \\
\text { [91] }\end{array}$ & 42 & $\begin{array}{l}\mathrm{PF} \\
\mathrm{PF}+1 \mathrm{wt} \% \mathrm{GO} / \mathrm{SiO}_{2}\end{array}$ & $\begin{array}{l}0.10 \\
0.18\end{array}$ & $\begin{array}{l}(100) \\
(180)\end{array}$ \\
\hline $\begin{array}{l}\text { Wang et } \\
\text { al. [92] }\end{array}$ & 40 & $\begin{array}{l}\mathrm{PF} \\
\mathrm{PF}+0.9 \mathrm{phr} \text { CoAl-LDH/GO }\end{array}$ & $\begin{array}{l}0.051 \\
0.079\end{array}$ & $\begin{array}{l}(100) \\
(155)\end{array}$ \\
\hline Yu et al. & 40 & $\mathrm{PF}$ & 0.10 & (100) \\
\hline
\end{tabular}




\begin{tabular}{|c|c|c|c|c|}
\hline [89] & & $\begin{array}{l}\text { PF + } 0.8 w t \% \text { expandable graphite } \\
\text { PF + } 0.8 w t \% \text { expanded graphite }\end{array}$ & $\begin{array}{l}0.17 \\
0.18\end{array}$ & $\begin{array}{l}(170) \\
(180)\end{array}$ \\
\hline $\begin{array}{c}\text { Guo et al. } \\
\text { [94] }\end{array}$ & - & $\begin{array}{l}\text { PF } \\
\text { PF lignin modified+ } 0.1 \text { wt\% nano } \mathrm{SiO}_{2}\end{array}$ & $\begin{array}{l}0.12 \\
0.38\end{array}$ & $\begin{array}{l}(100) \\
(316)\end{array}$ \\
\hline $\begin{array}{l}\text { Ma et al. } \\
\text { [38] }\end{array}$ & 50 & $\begin{array}{l}\mathrm{PF} \\
\mathrm{PF}+0.5 \% \mathrm{ZnO}\end{array}$ & $\begin{array}{l}0.256 \\
0.190\end{array}$ & $\begin{array}{l}(100) \\
(74)\end{array}$ \\
\hline $\begin{array}{l}\text { Yuan et } \\
\text { al. [45] }\end{array}$ & 25 & $\begin{array}{l}\text { PF } \\
\text { PF }+0.03 \text { phr PBA/Si lica core-shell particles }\end{array}$ & $\begin{array}{l}0.055 \\
0.080\end{array}$ & $\begin{array}{l}(100) \\
(145)\end{array}$ \\
\hline $\begin{array}{l}\text { Del Saz- } \\
\text { Orozco et } \\
\text { al. [61] }\end{array}$ & 120 & $\begin{array}{l}\text { PF } \\
\text { PF + } 8.5 w t \% \text { lignin particles } \\
P F+1.5 w t \% \text { wood floor particles }\end{array}$ & $\begin{array}{l}0.474 \\
0.824 \\
0.731\end{array}$ & $\begin{array}{l}(100) \\
(174) \\
(154)\end{array}$ \\
\hline $\begin{array}{l}\text { Zuo et al. } \\
\text { [58] }\end{array}$ & - & $\begin{array}{l}\text { PF } \\
\text { PF + } 10 \text { wt } \% \text { hollow glass beads } \\
\text { PF }+10 w t \% \text { pre-treated hollow glass beads }\end{array}$ & $\begin{array}{l}0.35 \\
1.03 \\
1.50\end{array}$ & $\begin{array}{l}(100) \\
(294) \\
(429)\end{array}$ \\
\hline $\begin{array}{l}\text { Song et al. } \\
\qquad \text { [17] }\end{array}$ & $\begin{array}{l}66 \\
50 \\
50\end{array}$ & $\begin{array}{l}\text { PF } \\
P F+0.5 \text { wt } \% \text { MWCNT } \\
\text { PF + } 1 \text { wt } \% \text { graphene }\end{array}$ & $\begin{array}{l}0.11 \\
0.14 \\
0.17\end{array}$ & $\begin{array}{l}(100) \\
(127) \\
(155)\end{array}$ \\
\hline $\begin{array}{l}\text { Zhou et } \\
\text { al. [33] }\end{array}$ & 80 & $\begin{array}{l}\text { PF } \\
\text { PF + } 0.9 w t \% \text { graphene oxide }\end{array}$ & $\begin{array}{l}2.20 \\
2.25\end{array}$ & $\begin{array}{l}(100) \\
(102)\end{array}$ \\
\hline $\begin{array}{l}\text { Zhuang et } \\
\text { al. [80] }\end{array}$ & 75 & $\begin{array}{l}\mathrm{PF} \\
\mathrm{PF}+1 \mathrm{wt} \% \text { modified attapulgite }\end{array}$ & $\begin{array}{l}0.393 \\
0.458\end{array}$ & $\begin{array}{l}(100) \\
(117)\end{array}$ \\
\hline $\begin{array}{l}\text { Rangari et } \\
\text { al. [52] }\end{array}$ & $\begin{array}{l}237 \\
314\end{array}$ & $\begin{array}{l}\mathrm{PF} \\
\mathrm{PF}+2 \% \text { Cloisite } \AA \text { clay }\end{array}$ & $\begin{array}{l}3.6 \\
8.7\end{array}$ & $\begin{array}{l}(100) \\
(242)\end{array}$ \\
\hline $\begin{array}{l}\text { Yang et al. } \\
\text { [35] }\end{array}$ & 50 & $\begin{array}{l}\text { PF } \\
P F+0.05 w t \% \text { pristine MWCNT } \\
P F+0.01 w t \% \text { MWCNT-COOH } \\
P F+0.05 w t \% \text { MWCNT-COOH } \\
P F+0.05 w t \% \text { MWNCT-NH2 }\end{array}$ & $\begin{array}{l}0.156 \\
0.213 \\
0.174 \\
0.223 \\
0.209\end{array}$ & $\begin{array}{l}(100) \\
(137) \\
(112) \\
(143) \\
(134)\end{array}$ \\
\hline $\begin{array}{c}\text { Yang et al. } \\
\text { [43] }\end{array}$ & 75 & $\begin{array}{l}P F \\
P F+5 w t \% \text { PU foam particles } \\
P F+10 w t \% \text { PU foam particles }\end{array}$ & $\begin{array}{l}0.43 \\
0.48 \\
0.41\end{array}$ & $\begin{array}{l}(100) \\
(112) \\
(95)\end{array}$ \\
\hline $\begin{array}{l}\text { Li et al. } \\
\text { [82] }\end{array}$ & 55 & $\begin{array}{l}\text { PF } \\
P F+3 w t \% ~ N B R P\end{array}$ & $\begin{array}{l}0.12 \\
0.14\end{array}$ & $\begin{array}{l}(100) \\
(117)\end{array}$ \\
\hline
\end{tabular}




\section{() Changes relative to the reference sample (100\%)}

\subsubsection{Reactive route}

Chemical modifications act mostly by improving the ability to deform the cell wall without breaking it by introducing flexible chains in the rigid backbone of the phenolic resin. This modification can reduce the crosslink density of the PF and contribute to higher strength. Different chemical routes are described in the literature. Among them, two major chemical groups that can be introduced in the phenolic backbone are of interest: glycol $[12,14,59]$ and urethane ethers $[46,83]$. Other authors have studied more original modification due to dicyandiamide [95] or epoxy components [49].

The introduction of PEG segments in the phenolic chemical structure is largely done to improve the compressive strength of PF since these segments are inserted in the phenolic resin backbone through condensation reactions and will impact the crosslinking density. The improvement of the compressive strength is connected to the PEG molar mass and its chemical structure. Gao et al. [14] observed a $192 \%$ improvement in the compressive strength with the addition of 11 wt\% PEG (1000 g. $\mathrm{mol}^{-1}$ ) in the foaming mixture. Yang et al. investigated the influence of the molar mass of phosphorous-modified PEG [51], where phosphorus-containing PEG (PPEG) was synthesized using phenyl dichlorophosphate (Figure 23). They noticed that the compressive strength increase was slightly higher when the molar mass of PPEG (10 wt\%) was $400(28 \%)$ instead of 600 g.mol ${ }^{-1}$ (24 \%). Indeed, a flexible that is too long chain will then deteriorate the compressive strength.

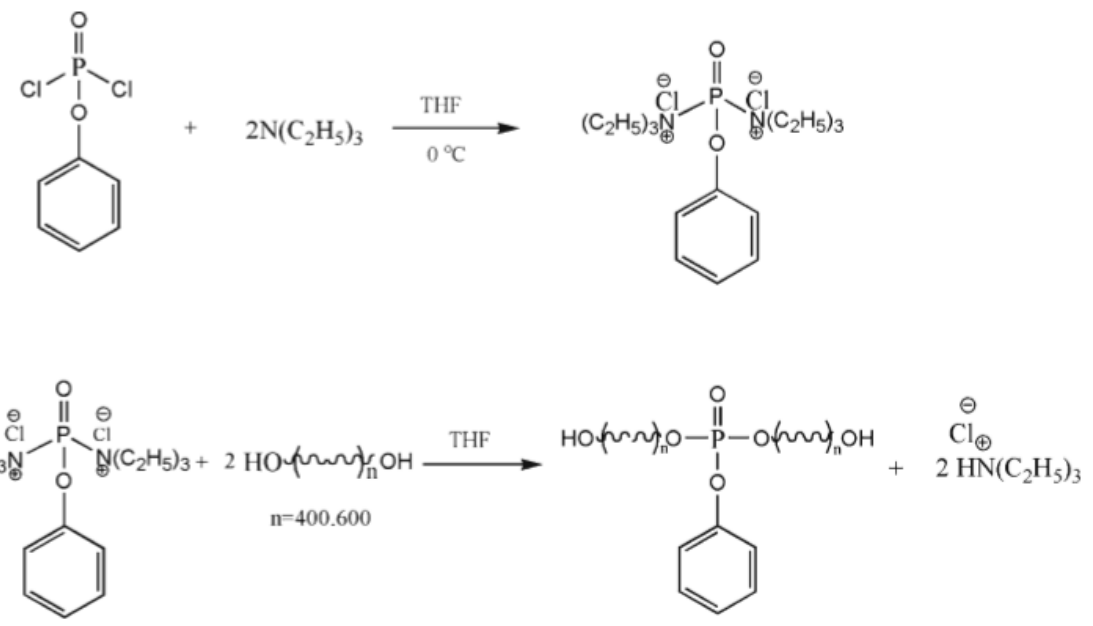

Figure 23. Schematic synthesis route of phosphorous PEG (PPEG) [59].

Liu et al [12] studied the effect of adding $4.5 \mathrm{wt} \%$ of a non-modified and a modified-boric acid PEG (PEG-BAE) on both compressive and flexural strengths. The functionality of modified-boric acid PEG (PEG-BAE) obtained by reaction between a PEG and boric acid (Figure 24 ) is equal to 3 , allowing the crosslinking with the methylol groups of the phenolic resin (Figure 25). The Figure 26 clearly shows 
that the addition of modified and non-modified PEG 400 improve both the compressive and flexural strengths. However, PEG-BAE 400 is more efficient because the effective flexible chain of PEG-BAE 400 is longer than that of PEG 400. Indeed, increasing the chain length to a certain range leads to a lower cross-link density and the material can obtain a higher strength. In a second work, they studied the effect of molar mass. The improvement of the compressive strength was $67 \%, 80 \%$ and $42 \%$ with the addition of 4.5 wt\% PEG-BAE 200, 400 and 600, respectively. These results indicate a critical molar mass of the PEG-BAE (400 g. mol ${ }^{-1}$ ) beyond which the crosslink density of PF is too low and causes the compressive strength to decrease. Moreover, the addition of PEG-BAE 600 induced a significant increase in the viscosity of the mixture that affected the distribution quality of the modifier and also degraded the final mechanical properties. Hu et al. [96], also observed good results with PF containing a Melamine Phosphate Borate PEG.

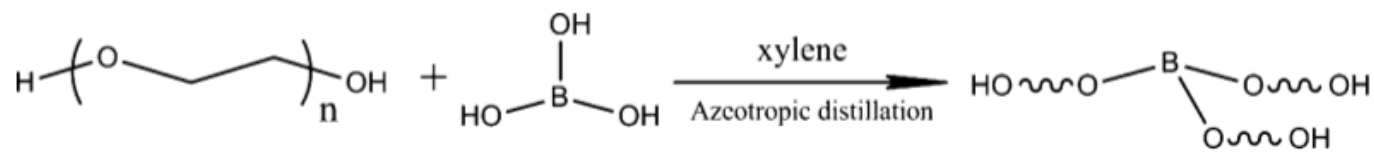

Figure 24. Synthesis and structure of PEG-BAE [12].

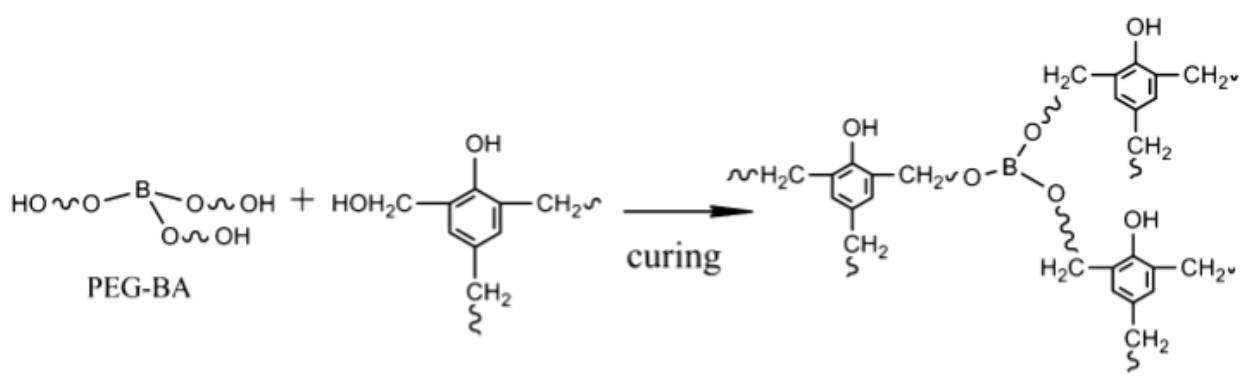

Figure 25. Possible reaction of PEG-BAE during curing of phenolic foams [12].

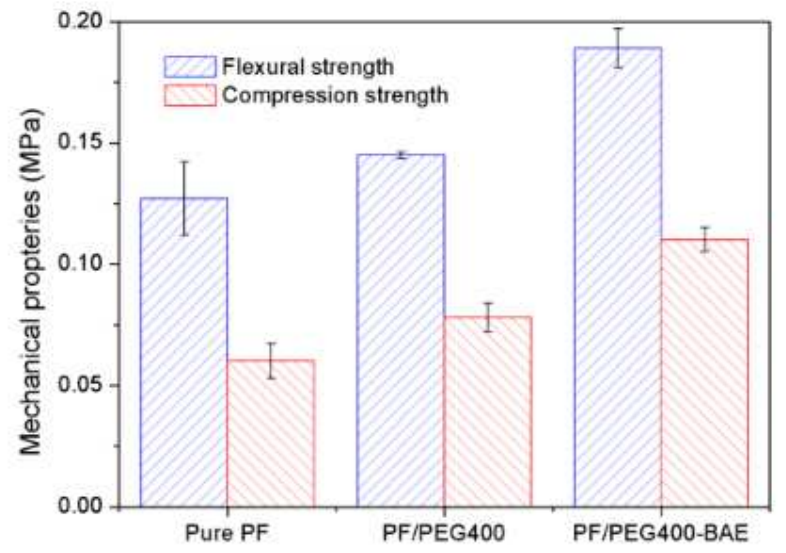

Figure 26. Flexural and compressive strength of PF foams and PF foams toughened with 4.5 wt\% of PEG400 and of PEG-BAE 400 [12]. 
A polyurethane addition has been also investigated to improve the compressive properties as well as maintain the flame retardancy of the foams. The isocyanate end groups of polyurethane react with the hydroxyl groups of the phenolic resins and introduce a flexible chain that is covalently bonded to the phenolic backbone. Ding et al. [83] introduced a new phosphorus and nitrogen containing polyurethane quasi-prepolymer (PNPUQP) (Figure 27) in the phenolic resin. The advantage of this polyurethane relies on the concurrent presence of flexible chains and the fire resistance brought by the phosphorus and nitrogen. An amount of $3 \mathrm{wt} \%$ of PNPUQP improved the compressive strength by $19 \%$.

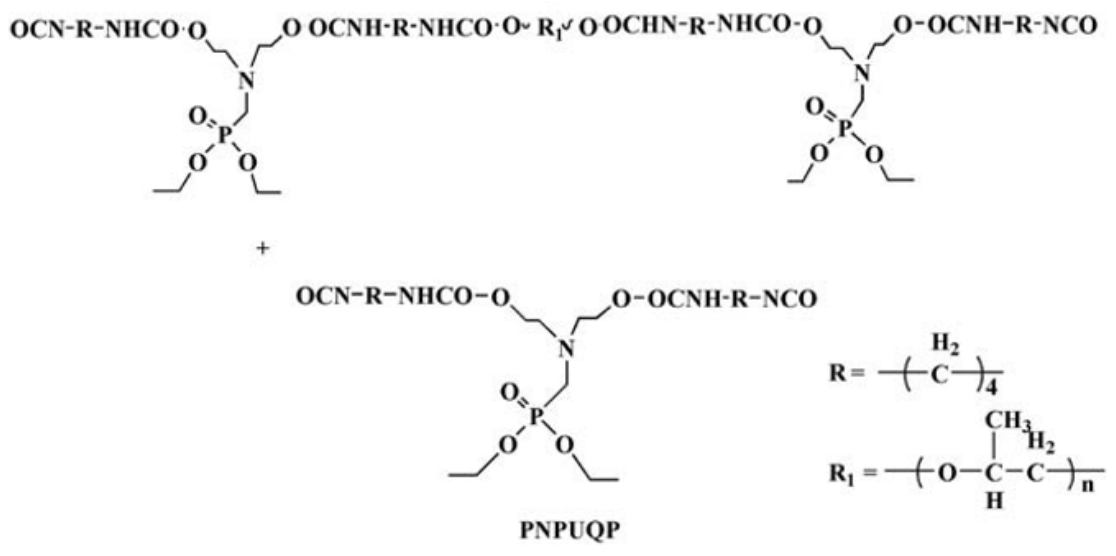

Figure 27. Structure of PNPUQP [83].

Yang et al. [46] was also interested in a novel phosphorus and silicon-modified polyurethane prepolymer (PSPUP) (Figure 28). They noticed that the addition of $3 \mathrm{wt} \%$ of the modified-PU led to a $136 \%$ increase in the compressive strength. Nevertheless, the density of the PSPUP modified phenolic resin (0.05) is higher than the density of non-modified one (0.033). Then, the real effect of the chemical modification is overestimated.

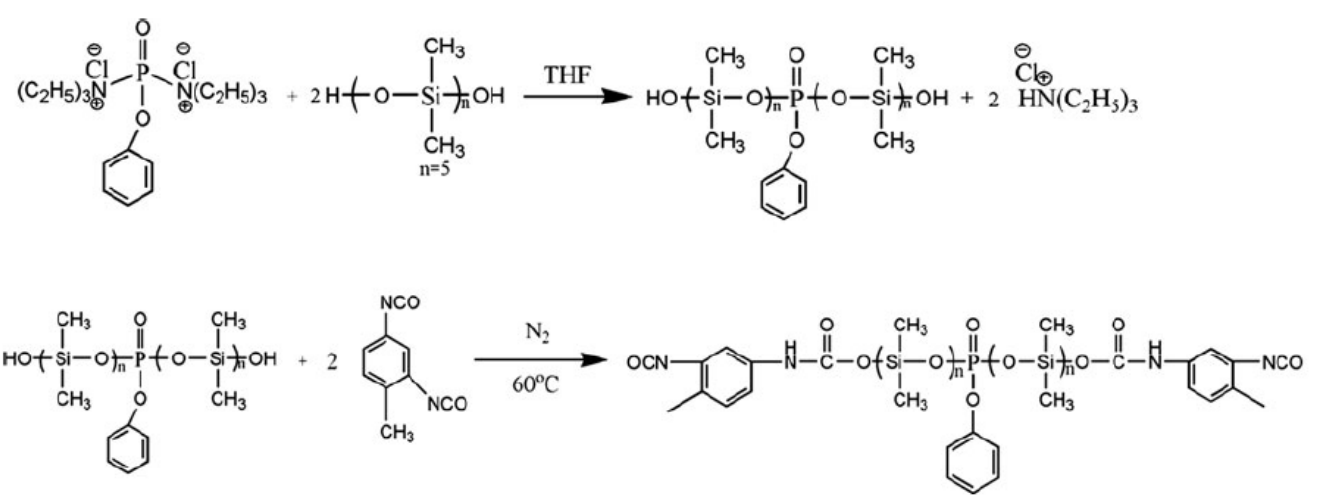

Figure 28. Schematic synthesis route of PSPUP [46].

Bo et al. [48] also tried to modify the foam formulation using a novel castor oil polyurethane prepolymer (COPUP) (Figure 29). This modification did not show successful results for the 
compressive strength, probably because of the significant decrease of the crosslinking due to the introduction of long and flexible chains of COPUP in the mixture.

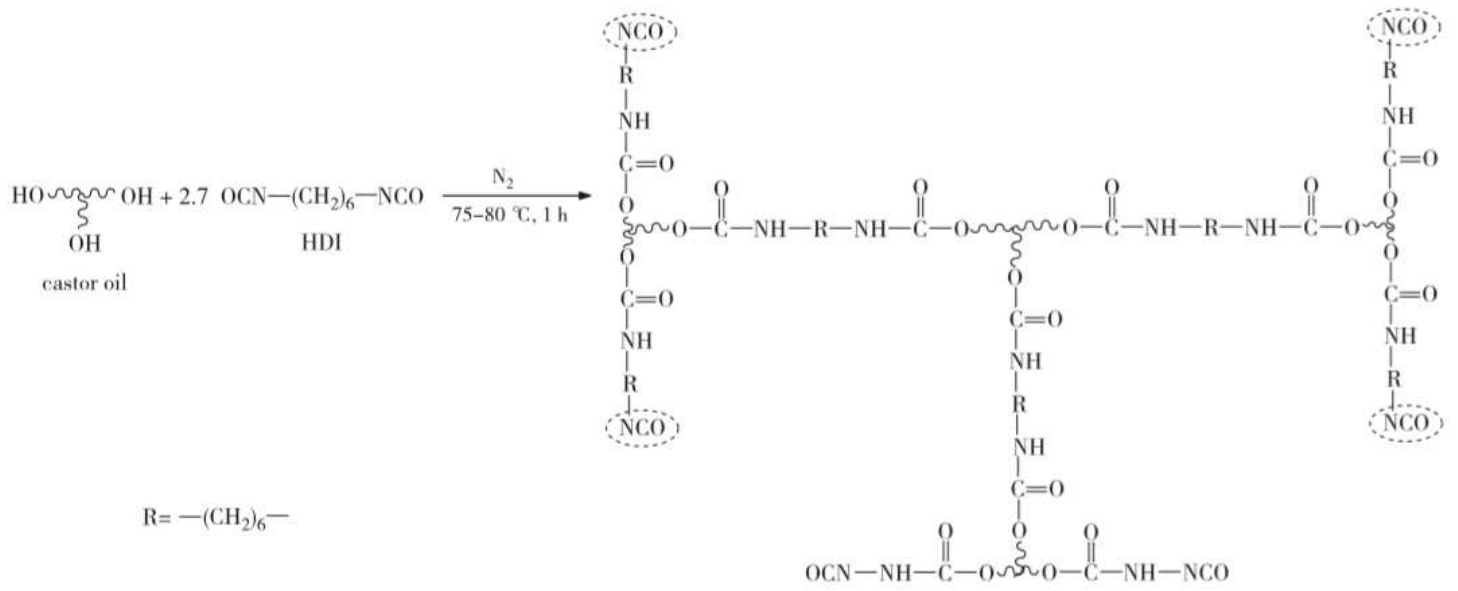

Figure 29. The schematic synthesis route of COPUP [48].

An original study [95] investigated the effect of PF modified with dicyandiamide. The modification is illustrated in Figure 30. Gao et al. showed a 180\% improvement with the addition of $8 \%$ of dicyandiamide to the formulation. Authors attributed this reinforcement to the flexible chain nature in the dicyandiamide-formaldehyde resin, as for PEG or polyurethane.

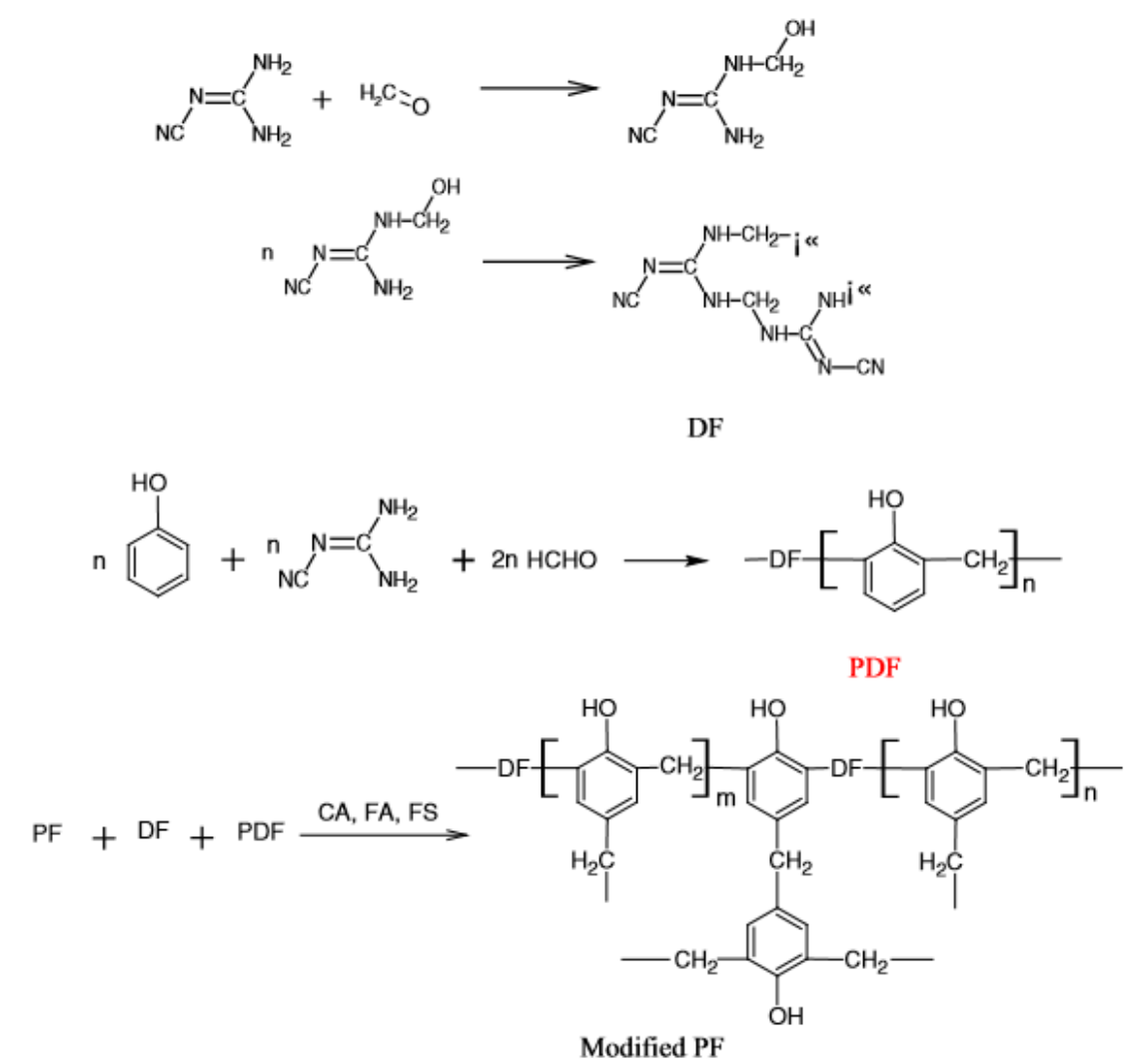

Figure 30. Synthesis of phenolic foams modified with dicyandiamide [95]. 
Xu et al. [49] studied the influence of an epoxy-modified phenol-formaldehyde resin. Although the density of the foams increased from 0.13 to 0.23 , the compressive strength increased from $0.57 \mathrm{MPa}$ to $108.20 \mathrm{MPa}$, corresponding to an unreasonable improvement of $19000 \%$. Thus, the reported results seem to be anomalous.

Finally, dicyandiamide modification offered the best enhancement to the compressive strength. Polyurethanes also presented an excellent improvement with the phosphorus and silicon-modified polyurethane prepolymer (PSPUP) as well as more moderate improvement like with phosphorus and nitrogen containing polyurethane quasi-prepolymer (PNPUQP). This is certainly due to the chain structure of polyurethane used. A similar tendency has been obtained with the PEG groups. Table 6 presents an exhaustive list of compressive strength property of several chemically modified PF.

Table 6. Compressive strength of several modified phenolic foams.

\begin{tabular}{|c|c|c|c|c|}
\hline Reference & $\begin{array}{l}\text { Density } \\
{\left[\mathrm{kg} \cdot \mathrm{m}^{-3}\right]}\end{array}$ & Foam type & \multicolumn{2}{|c|}{$\begin{array}{l}\text { Compressive strength } \\
\text { [MPa] }\end{array}$} \\
\hline $\begin{array}{l}\text { Gao et al. } \\
\text { [95] }\end{array}$ & $47-54$ & $\begin{array}{l}\mathrm{PF} \\
\mathrm{PF}+8 \% \text { dicyandiamide }\end{array}$ & $\begin{array}{l}0.125 \\
0.350\end{array}$ & $\begin{array}{l}(100) \\
(280)\end{array}$ \\
\hline $\begin{array}{c}\text { Xu et al. } \\
\text { [49] }\end{array}$ & $\begin{array}{l}129 \\
233\end{array}$ & $\begin{array}{l}\mathrm{PF} \\
\mathrm{PF}+10 \text { wt } \% \text { epoxy }\end{array}$ & $\begin{array}{l}0.57 \\
108\end{array}$ & $\begin{array}{l}(100) \\
(18982)\end{array}$ \\
\hline $\begin{array}{l}\text { Bo et al. } \\
\text { [48] }\end{array}$ & 38 & $\begin{array}{l}\mathrm{PF} \\
\mathrm{PF}+7 \% \text { castor oil-based PU prepolymer }\end{array}$ & $\begin{array}{l}0.14 \\
0.13\end{array}$ & $\begin{array}{l}(100) \\
(93)\end{array}$ \\
\hline $\begin{array}{l}\text { Ding et al. } \\
\text { [83] }\end{array}$ & 55 & $\begin{array}{l}\mathrm{PF} \\
\mathrm{PF}+3 \% \mathrm{PNPUQP}\end{array}$ & $\begin{array}{l}0.137 \\
0.163\end{array}$ & $\begin{array}{l}(100) \\
(119)\end{array}$ \\
\hline $\begin{array}{l}\text { Liu et al. } \\
\qquad \text { [12] }\end{array}$ & 25 & $\begin{array}{l}P F \\
P F+4.5 w t \% \text { PEG } 200 \text { BAE } \\
P F+4.5 w t \% \text { PEG } 400 \text { BAE } \\
P F+4.5 w t \% \text { PEG } 600 \text { BAE }\end{array}$ & $\begin{array}{l}0.060 \\
0.100 \\
0.108 \\
0.085\end{array}$ & $\begin{array}{l}(100) \\
(167) \\
(180) \\
(142)\end{array}$ \\
\hline $\begin{array}{l}\text { Gao et al. } \\
\text { [14] }\end{array}$ & $47-54$ & $\begin{array}{l}\mathrm{PF} \\
\mathrm{PF}+11 w t \% \mathrm{PEG}\end{array}$ & $\begin{array}{l}0.12 \\
0.35\end{array}$ & $\begin{array}{l}(100) \\
(292)\end{array}$ \\
\hline $\begin{array}{l}\text { Hu et al. } \\
{[96]}\end{array}$ & - & $\begin{array}{l}\text { PF } \\
\text { PF + } 8 \text { phr PEG/ } 4 \text { phr MPB }\end{array}$ & $\begin{array}{l}0.05 \\
0.09\end{array}$ & $\begin{array}{l}(100) \\
(180)\end{array}$ \\
\hline $\begin{array}{c}\text { Yang et al. } \\
{[46]}\end{array}$ & $\begin{array}{l}33 \\
50\end{array}$ & $\begin{array}{l}\text { PF } \\
P F+3 w t \% \text { PSPUP }\end{array}$ & $\begin{array}{l}0.123 \\
0.290\end{array}$ & $\begin{array}{l}(100) \\
(236)\end{array}$ \\
\hline Yang et al. & $40-45$ & $\mathrm{PF}$ & 0.114 & $(100)$ \\
\hline
\end{tabular}


\begin{tabular}{l|l|l} 
[59] & $\begin{array}{l}\text { PF }+10 w t \% \text { PPEG } 400 \\
\text { PF }+10 w t \% \text { PPEG 600 }\end{array}$ & 0.146 \\
0.141
\end{tabular}

() Changes relative to the reference sample (100\%)

In summary regarding the compressive strength, the fibre reinforcement route highlighted that glass fibres provide the best improvement due to their relatively high stiffness and high degree of orientation along the foaming direction. This last point has also the disadvantage of making the final foams less isotropic, in contrast to findings for aramid fibres. The enhancement can be increased further with chemical modification of the fibre surface that improves the compatibility between fibres and the resin matrix.

Various types of nano- or microparticles are used for particle reinforcement. As for fibres, interactions between the particles and resin matrix play a fundamental role in the improvement of the compressive strength. Covalent bonding between the particles and the resin especially allows a dissipation of a part of the stress generated during compression and decreases the crosslink density of the resin, which then increases the ability to modified foams to be warped. Upon combining these two effects, particles can enhance the PF compressive property.

The chemical route for reinforcing the compressive strength relies on the formation of covalent bonds between the added species and the phenolic resin. The flexibility of the added entity that is linked to the rigid backbone of the phenolic resin contributes to increasing the ability of the foam to be warped. Nevertheless, this reduces the crosslink ability of the phenolic resin, which could be interesting if the decrease is limited because the structure will keep its rigidity while its flexibility is improved. Among the various chemical pathways, the addition of PEG is particularly efficient for improving the compressive strength according to the molar mass. Then PEG 400 seems to have the greatest potential as a toughening agent, especially when a modification with boron elements is applied.

Nevertheless, we must keep in mind that these reinforcement routes, especially filler addition, may increase the mixture viscosity, hinder the homogenous distribution of the additives and dramatically influence the foaming process and the final foam properties. Hence, the formulation generally needs further optimization to find the suitable amount of new constituent.

\subsection{Flexural strength}

The flexural strength represents the resistance of a material against flexion. This is defined as the stress in a material just before it yields in a flexion test. Studies have aimed at improving the flexural strength and increase the strain at break, which could be in opposition. 


\subsubsection{Additive route: fibres and particles reinforcement}

Flexural strength can be improved using fibres, but it is mainly studied by the addition of particles. It has been reported that the stiffness of the fillers $[47,82,86]$, their aspect ratio $[30,87]$, the creation of covalent bonding with the phenolic matrix $[30,87][45]$ and a more uniform microstructure $[30$, 82,87 ] are different parameters that increase the flexural strength. Moreover, a suitable number of particles has to be added to find the optimal balance between the different factors $[30,45,87]$.

To our knowledge, few authors reported the effect of fibres on flexural strength. Yuan et al. [47] found that the high stiffness of glass fibres enhanced the flexural strength. They observed that the addition of only $0.5 \mathrm{wt} \%$ of glass fibres $(L=6.4 \mathrm{~mm}, \mathrm{D}=10 \mu \mathrm{m})$ improved the flexural strength by $35 \%$. Modified wood fibres improved also the flexural strength [85].

Flexural strength can also be improved by the incorporation of particles that strongly interact with the phenolic resin. Yuan et al. [45] added poly(n-butyl acrylate)/silica core-shell particles ( $D=180$ $\mathrm{nm}$ ) to the phenolic resin and found a $35 \%$ improvement in the flexural strength due to the covalent bond formation between the hydroxymethyl groups of the phenolic resin and the silanol groups of the particles. Nevertheless, if the amount of the added nanocomposites was too high, the viscosity increased drastically and the particles were not well dispersed. Moreover, the curing process and the formation of the network structure were disturbed; hence, some defects were created, leading to stress concentration [45].

Nevertheless, the role of soft particles is more complex since they improve the cell size uniformity but alter the rigid structure of the PF. Li et al. [82] reported this ambivalence with the addition of 3 wt\% nitrile butadiene rubber powder and no significant effect on flexural strength was observed.

Li et al. [30, 87] showed that the flexural strength of modified PF is improved by the same parameters as compressive strength: the ultrahigh aspect ratio of the particles, the strong interactions with the phenolic resin and the higher cell density of the modified foams. The addition of 0.5 and $4.0 \mathrm{phr}$ graphene oxide was reported to improve the flexural strength of the foams up to $9 \%$ and $14 \%$, respectively, whereas the addition of $0.5 \mathrm{phr}$ silica enhanced the flexural property by only $2 \%$. The addition of silica-graphene oxide (SGO) hybrid increased the flexural strength up to $32 \%$. A similar result was obtained for the alpha zirconium phosphate/graphene oxide (ZGO) hybrid. The improvement was about $29 \%$ while the $\alpha$-ZrP alone increased the flexural property by only $7 \%$. Hence, as for compressive strength, these hybrids showed a synergy that improves the flexural 
strength. As previously pointed out, different authors have also studied modified GO and observed similar results $[90,92]$.

The use of clay instead of pentane as a blowing agent through $\mathrm{CO}_{2}$ release was also found to improve flexural strength. The reinforcing effect could be due to the stiffness of the particles as well as possible chemical interactions between $\mathrm{CaCO}_{3}$ and the phenolic matrix. Riahi et al. [97] indicated that incorporating $6 \mathrm{phr}$ clay $(\mathrm{D}=27-35 \mu \mathrm{m})$ into the foams improved the flexural value by $61 \%$. With the introduction of clay, the density increased from 0.055 to 0.069 , which could partially explain the flexural strength increase provided by it. The effect of zinc oxide added with flame retardant was comparable to that observed on compressive strength [38], as results showed a decrease of flexural strength once again.

Finally, better results were obtained by the incorporation of glass fibres. Moreover, the combination with a polyurethane chemical modification enhanced the reinforcement. Nevertheless, the use of SGO and ZGO provide good enhancements. Flexural strengths measured on several reinforced PF are listed in Table 7.

Table 7. Flexural strength of several reinforced phenolic foams.

\begin{tabular}{|c|c|c|c|c|}
\hline Reference & $\begin{array}{l}\text { Density } \\
{\left[\mathrm{kg} \cdot \mathrm{m}^{-3}\right]}\end{array}$ & Foam type & \multicolumn{2}{|c|}{$\begin{array}{l}\text { Flexural strength } \\
{[\mathrm{MPa}]}\end{array}$} \\
\hline $\begin{array}{l}\text { Yuan et } \\
\text { al. [47] }\end{array}$ & $\begin{array}{l}48 \\
48 \\
53\end{array}$ & $\begin{array}{l}P F \\
P F+0.5 w t \% \text { glass fibres } \\
P F+0.5 w t \% \text { glass fibres }+3 w t \% \text { DOPU }\end{array}$ & $\begin{array}{l}0.202 \\
0.273 \\
0.340\end{array}$ & $\begin{array}{l}(100) \\
(135) \\
(168)\end{array}$ \\
\hline $\begin{array}{c}\text { Ma et al. } \\
\text { [85] }\end{array}$ & - & $\begin{array}{l}\text { PF } \\
P F+4 \text { wt } \% \text { modified wood fibres }\end{array}$ & $\begin{array}{l}0.08 \\
0.15\end{array}$ & $\begin{array}{l}(100) \\
(188)\end{array}$ \\
\hline $\begin{array}{l}\text { Li et al. } \\
\text { [30] }\end{array}$ & 16 & $\begin{array}{l}\mathrm{PF} \\
\mathrm{PF}+4 \mathrm{phr} \mathrm{ZGO} \\
\mathrm{PF}+4 \mathrm{phr} \mathrm{GO} \\
\mathrm{PF}+4 \mathrm{phr} \alpha-\mathrm{ZrP}\end{array}$ & $\begin{array}{l}0.14 \\
0.18 \\
0.16 \\
0.15\end{array}$ & $\begin{array}{l}(100) \\
(129) \\
(114) \\
(107)\end{array}$ \\
\hline $\begin{array}{l}\text { Li et al. } \\
\text { [87] }\end{array}$ & 16 & $\begin{array}{l}\mathrm{PF} \\
\mathrm{PF}+1.5 \mathrm{phr} \mathrm{SGO} \\
\mathrm{PF}+0.5 \mathrm{phr} \mathrm{SiO} 2 \\
\mathrm{PF}+0.5 \mathrm{phr} \mathrm{GO}\end{array}$ & $\begin{array}{l}0.136 \\
0.179 \\
0.139 \\
0.148\end{array}$ & $\begin{array}{l}(100) \\
(132) \\
(102) \\
(109)\end{array}$ \\
\hline
\end{tabular}




\begin{tabular}{|c|c|c|c|c|}
\hline $\begin{array}{l}\text { Liu et al. } \\
\text { [90] }\end{array}$ & - & $\begin{array}{l}\mathrm{PF} \\
\mathrm{PF}+4 \text { phr Mg-rGO }\end{array}$ & $\begin{array}{l}0.131 \\
0.188\end{array}$ & $\begin{array}{l}(100) \\
(144)\end{array}$ \\
\hline $\begin{array}{l}\text { Wang et } \\
\text { al. [92] }\end{array}$ & 40 & $\begin{array}{l}\mathrm{PF} \\
\mathrm{PF}+0.9 \mathrm{phr} \mathrm{COAl}-\mathrm{LDH} / \mathrm{GO}\end{array}$ & $\begin{array}{l}0.128 \\
0.173\end{array}$ & $\begin{array}{l}(100) \\
(135)\end{array}$ \\
\hline $\begin{array}{l}\text { Ma et al. } \\
\text { [38] }\end{array}$ & 50 & $\begin{array}{l}\mathrm{PF} \\
\mathrm{PF}+0.5 \% \mathrm{ZnO}\end{array}$ & $\begin{array}{l}0.40 \\
0.29\end{array}$ & $\begin{array}{l}(100) \\
(73)\end{array}$ \\
\hline $\begin{array}{l}\text { Yuan et } \\
\text { al. [45] }\end{array}$ & 25 & $\begin{array}{l}\text { PF } \\
\text { PF }+0.03 \text { phr PBA/Silica core-shell particles }\end{array}$ & $\begin{array}{l}0.155 \\
0.210\end{array}$ & $\begin{array}{l}(100) \\
(135)\end{array}$ \\
\hline $\begin{array}{l}\text { Riahi et } \\
\text { al. [97] }\end{array}$ & $\begin{array}{l}55 \\
69\end{array}$ & $\begin{array}{l}\mathrm{PF} \\
\mathrm{PF}+6 \text { phr clay }\end{array}$ & $\begin{array}{l}0.085 \\
0.137\end{array}$ & $\begin{array}{l}(100) \\
(161)\end{array}$ \\
\hline $\begin{array}{l}\text { Li et al. } \\
\text { [82] }\end{array}$ & 55 & $\begin{array}{l}\mathrm{PF} \\
\mathrm{PF}+3 w t \% \mathrm{NBRP}\end{array}$ & $\begin{array}{l}0.24 \\
0.25\end{array}$ & $\begin{array}{l}(100) \\
(104)\end{array}$ \\
\hline
\end{tabular}

() Changes relative to the reference sample (100\%)

\subsubsection{Reactive route}

Chemical modifications of PF are classically performed due to polyethylene glycol or polyurethane components. They introduce flexible chains in the rigid backbone of the phenolic resin and reduce the crosslinking density. Hence, the flexural strength is generally improved. Nevertheless, the decrease in crosslinking density must be controlled, since a very low crosslinking level causes a significant decrease in mechanical properties.

The PEG family has shown the importance of the chain length and crosslink density to optimize the foam modification. Sui et al. [13] studied the effect of phosphated PEG (PEGP) with different molar masses. The modification was conducted using phosphorus pentoxide, as illustrated in Figure 31 . The flexural strength was increased by $12 \%, 15 \%$ and $7 \%$ with the addition of 6 wt\% of a PEG 200 , PEG 400 and PEG 600, respectively (Figure 32). The authors explained that above 6 wt\%, the crosslinking density dramatically decreased, which deteriorated the flexural strength. Moreover, the highest strength was obtained with PEG 400, corresponding to the suitable chain length assuring the appropriate balance between flexibility and stiffness.

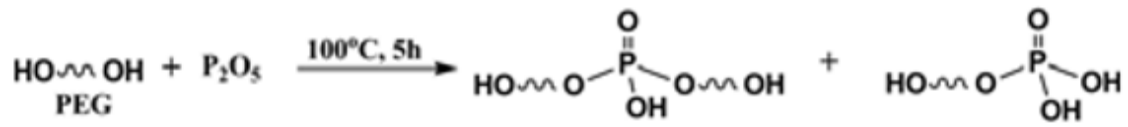

Figure 31: Schematic synthesis route of PEGP [13]. 


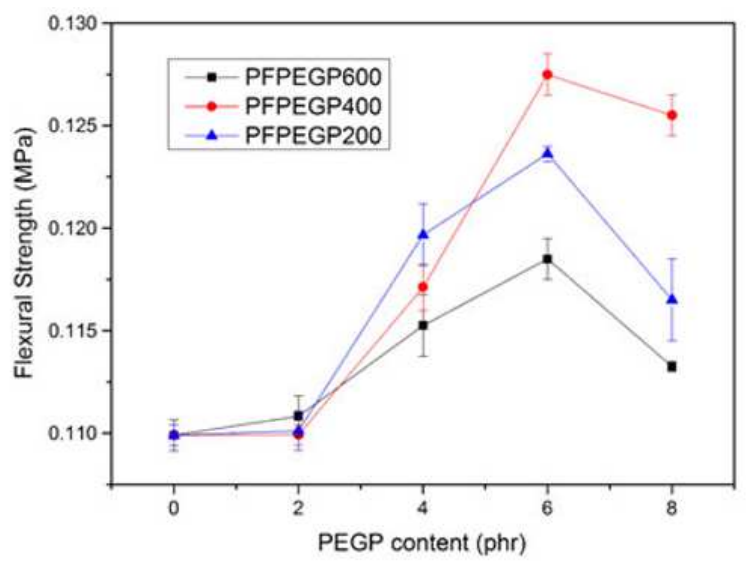

Figure 32. Effect of PEGP content and molar mass on flexural strength of modified phenolic foams [13].

Liu et al. [12] confirmed the results of Sui et al. [13]. They introduced the optimized value of $4.5 \mathrm{wt} \%$ of a boric acid-modified- PEG in the phenolic resin (Figure 24) and values increased to $36 \%, 52 \%$, and $24 \%$ with modified PEG 200, 400 and 600, respectively (Figure 33). Moreover, this modification with B seems to be more efficient than PPEG based on the results in Table I.2. Contrary to these results, Yang et al. [59] observed no change of the flexural strength with the addition of $10 \mathrm{wt} \%$ of PPEG 400 whereas the modified PEG 600 showed an improvement of $14 \%$. Hu et al. [96], also observed an improved behaviour of PF containing a Melamine Phosphate Borate PEG.

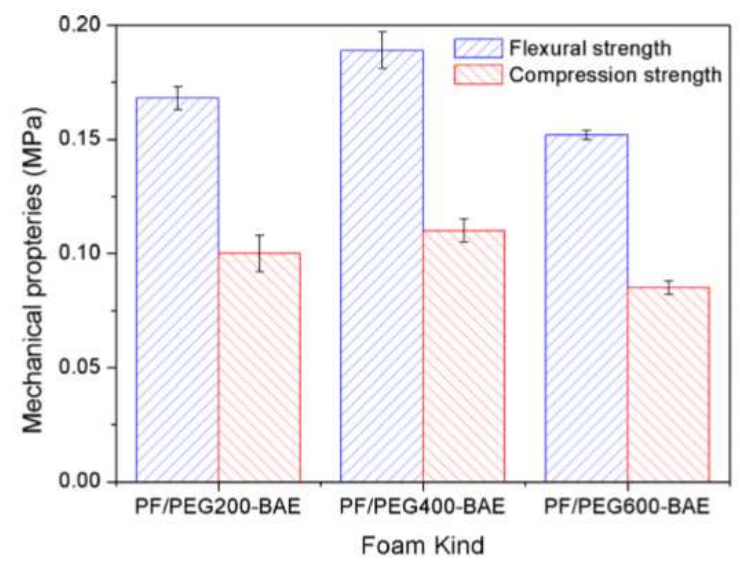

Figure 33. Flexural and compressive strengths of phenolic foams toughened by PEG-BAE with different molar masses [12].

Polyurethane modification [46, 83], like PEG modification [12, 14, 59], is based on the introduction of flexible and long chains that cause a reduction in the crosslinking density. The PU modification relies on the reaction between NCO groups of PU and hydroxymethyl groups of phenolic resin. Results reported by Bo et al. [48] showed the successful improvement in flexural values, which increased by $26 \%$ with the addition of $7 \%$ of castor oil based polyurethane prepolymer. On the other hand, the compressive strength decreased by $7 \%$. This difference in behaviour is explained by the introduction 
of flexible chains into the rigid backbone of phenolic resin. Ding et al. [83] investigated flexural behaviour by adding PU quasi prepolymer containing phosphorus and nitrogen Results showed an improvement of $15 \%$ with $3 w t \%$ of PNPUQP.

As described above, Yuan et al. [47] improved the flexural strength by $35 \%$ with $0.5 \mathrm{wt} \%$ of glass fibres. The combination of $0.5 \mathrm{wt} \%$ of glass fibres and $3 \mathrm{wt} \%$ of a phosphorus containing polyurethane results in an enhancement up to $68 \%$. This improvement is due to the combined effects of stiff fibres and the decrease in crosslinking density due to polyurethane introduction in the phenolic backbone.

The influence of an epoxy-modified PF reported by $\mathrm{Xu}$ et al. [49] showed an outstanding enhancement of $156 \%$ by introducing $10 \mathrm{wt} \%$ of the epoxy modified resin. Nevertheless, the density changed from 0.13 to 0.23 , hence it is difficult to draw conclusions about the effect of the epoxy addition.

Few other ways were tested to improve the flexural strength of PF. The addition of cardanol (10 wt\%) in the preparation of phenolic resin, obtained through bis-phenol modification, significantly increased the flexural strength of PF [42] due to the introduction of chains more flexible than the phenolic resin (Figure 34). Nevertheless, above $10 \mathrm{wt} \%$, the flexural and compressive properties decreased because defects formed in the cell structure.
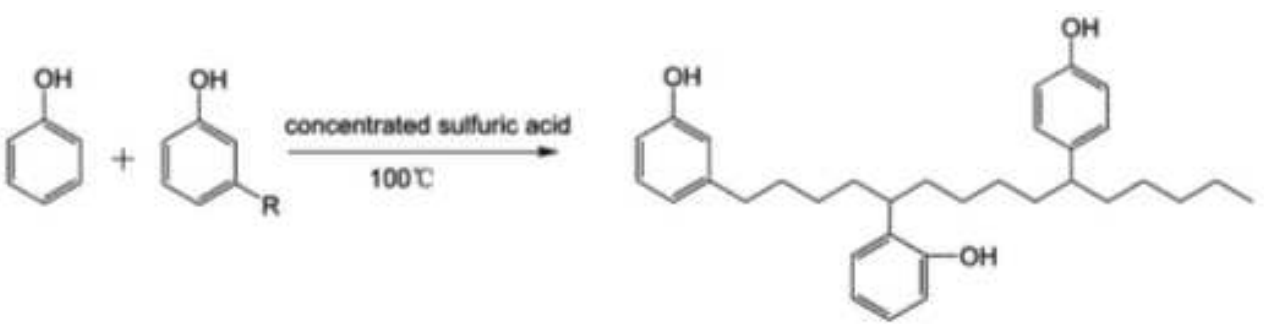

Figure 34. Cardanol reaction with phenol via Friedel-Craft alkylation [42] $\left(R=\mathrm{C}_{15} \mathrm{H}_{31-n}\right)$.

Finally, PEG or PU family can provide comparable enhancement depending on the structure of the added molecule. Table 8 summarizes the list of the cited papers on PF flexural properties.

Table 8. Flexural strength of several modified phenolic foams.

\begin{tabular}{c|c|l|lr} 
Reference & $\begin{array}{c}\text { Density } \\
{\left[\mathrm{kg} \cdot \mathrm{m}^{-3}\right]}\end{array}$ & Foam type & \multicolumn{2}{|c}{ Flexural strength } \\
{$[\mathrm{MPa}]$}
\end{tabular}




\begin{tabular}{|c|c|c|c|c|}
\hline $\begin{array}{c}\text { Bo et al. } \\
{[48]}\end{array}$ & 38 & \begin{tabular}{|l}
$\mathrm{PF}$ \\
$\mathrm{PF}+7 \%$ castor oil-based PU prepolymer
\end{tabular} & $\begin{array}{l}0.19 \\
0.24\end{array}$ & $\begin{array}{l}(100) \\
(126)\end{array}$ \\
\hline $\begin{array}{c}\text { Ding et al. } \\
\text { [83] }\end{array}$ & 55 & \begin{tabular}{|l|}
$\mathrm{PF}$ \\
$\mathrm{PF}+3 \% \mathrm{PNPUQP}$
\end{tabular} & $\begin{array}{l}0.254 \\
0.291\end{array}$ & $\begin{array}{l}(100) \\
(115)\end{array}$ \\
\hline $\begin{array}{l}\text { Liu et al. } \\
\text { [12] }\end{array}$ & 25 & $\begin{array}{l}\text { PF } \\
P F+4.5 w t \% \text { PEG } 200 \text { BAE } \\
P F+4.5 w t \% \text { PEG } 400 \text { BAE } \\
P F+4.5 w t \% \text { PEG } 600 \text { BAE }\end{array}$ & $\begin{array}{l}0.125 \\
0.170 \\
0.190 \\
0.155\end{array}$ & $\begin{array}{l}(100) \\
(136) \\
(152) \\
(124)\end{array}$ \\
\hline $\begin{array}{l}\text { Jing et al. } \\
\text { [42] }\end{array}$ & 26 & $\begin{array}{l}\mathrm{PF} \\
\mathrm{PF}+10 \text { wt\% cardanol }\end{array}$ & $\begin{array}{l}0.10 \\
0.12\end{array}$ & $\begin{array}{l}(100) \\
(125)\end{array}$ \\
\hline $\begin{array}{c}\text { Hu et al. } \\
\text { [96] }\end{array}$ & - & $\begin{array}{l}\text { PF } \\
\text { PF + } 8 \text { phr PEG/ } 4 \text { phr MPB }\end{array}$ & $\begin{array}{l}0.13 \\
0.20\end{array}$ & $\begin{array}{l}(100) \\
(155)\end{array}$ \\
\hline $\begin{array}{l}\text { Sui et al. } \\
\text { [13] }\end{array}$ & 20 & $\begin{array}{l}\text { PF } \\
\text { PF + } 6 w t \% \text { PEGP } 200 \\
\text { PF + } 6 w t \% \text { PEGP } 400 \\
P F+6 w t \% \text { PEGP } 600\end{array}$ & $\begin{array}{l}0.110 \\
0.123 \\
0.127 \\
0.118\end{array}$ & $\begin{array}{l}(100) \\
(112) \\
(115) \\
(107)\end{array}$ \\
\hline $\begin{array}{l}\text { Yang et al. } \\
\text { [59] }\end{array}$ & $40-45$ & $\begin{array}{l}\text { PF } \\
\text { PF + } 10 w t \% \text { PPEG } 400 \\
\text { PF + } 10 w t \% \text { PPEG } 600\end{array}$ & $\begin{array}{l}0.214 \\
0.213 \\
0.245\end{array}$ & $\begin{array}{l}(100) \\
(99) \\
(114)\end{array}$ \\
\hline
\end{tabular}

\section{() Changes relative to the reference sample (100\%)}

To conclude, the pathways used to increase the flexural strength are the same as those previously described in the compressive strength studies. The improvement relies on the strong interactions between the particles and the resin matrix. The stiffness of the fillers may favour an increase in the flexural strength. No clear information was provided on the appropriate amount of fillers. Moreover, in some cases a high content might create defects that lead to stress concentrations. Finally, the density of the foams is affected by the addition of fillers in some studies, which has to be taken into account when interpreting the results.

The flexibility provided by added species that are covalently introduced in the rigid phenolic resin backbone reduces the crosslinking density and thus improves the flexural strength. Oligomers of polyethylene glycol that have flexible chains are good candidates. Except for one study [51], the most efficient one seems to be PEG with a molar mass of $400 \mathrm{~g} \cdot \mathrm{mol}^{-1}$. The decrease in crosslinking density 
must be controlled since a crosslinking level that is too low causes a significant decrease in mechanical properties.

\subsection{Friability}

The friability represents the ease of a material to break into small pieces under pressure or by rubbing. The friability can be problematic for the final properties of the foam according to the targeted applications. Furthermore, it causes health hazards due to the formation of pulverous material.

Two techniques are used to evaluate this property according to the desired applications. The first one, which is more related to abrasion, consists of placing specimens with a certain mass on a fixed sand paper (with a fixed mesh) and then moving the specimens back and forth for several times in horizontal direction $[83,98]$. The second method, according to the ASTM C421 standard, deals more with the friability caused by numerous repetitive small impacts. To do so, 12 cubes with a $25.4 \mathrm{~mm}$ side length are mixed with 24 oak cubes with a $19.0 \mathrm{~mm}$ side length in a tumbling box [10, 33]. The tumbling time is $10 \mathrm{~min}$ at $60 \mathrm{rpm}$. For the two methods, mass loss or the pulverization ratio, $\mathbf{w}_{1}$, is calculated according to Equation 6:

$$
\mathbf{W}_{\mathbf{l}}=\frac{\mathbf{W}_{\mathrm{i}}-\mathbf{W}_{\mathrm{f}}}{\mathbf{W}_{\mathrm{i}}}
$$

where $W_{i}$ and $W_{f}$ are the initial and the final masses of the foams samples, respectively.

\subsubsection{Additive route: Inorganic fibres and particles}

The addition of fibres or particles is the most reported method in the literature to reduce the friability of PF and show mostly positive effects. Besides the nature of the particles (strength, aspect ratio, size), several important factors were identified for the reinforcement of PF. The most important is the interaction between the particles and the phenolic resin in order to create strong covalent bond $[31,33,57,87]$. If strong bonds are created the friability is quite improved, whereas the friability property may be degraded if no bonding occurs. Toughness of the cell walls is also of great importance and can be improved by embedding particles of fibres in it, ensuring the protection of the cells $[10,36,61]$. Moreover, for flexible fibres, an efficient micro-peel process can occur that allows the dissipation of large amounts of energy $[10,99]$. Finally, fibres or particles usually act as nucleating agents that favour the formation of a lower cell size and a higher cell density and the reduction of defect formation $[30,87]$. Obviously, for all factors presented above, a good dispersion of the particles and fibres is required. 
Two types of fibres have been studied: glass [10,98] and aramid [10,57]. The addition of glass fibres usually induces a slight decrease in the friability whereas aramid ones decrease the friability very efficiently. For glass fibres, the decrease in the friability relies on the increase in the toughness of the PF [10] because fibres are stiffer than the phenolic matrix. Shen et al. [99] demonstrated that aramid fibres, characterized by their poor stiffness in comparison with glass fibres, dissipated a great deal of energy through a micropeel process during crack propagation by decreasing the stress concentration and inducing secondary cracks. For glass fibres, this micro peel process was not observed, which is why the improvement was lower [99].

Yang et al. [98] observed that the introduction of $5 \mathrm{wt} \%$ glass fibres $(L=6.4 \mathrm{~mm}, D=10 \mu \mathrm{m})$ in the foams formulation resulted in a $18 \%$ friability decrease. Shen et al. [10] compared the efficiency of glass and aramid fibres $(L=6.4 \mathrm{~mm}, D=12 \mu \mathrm{m})$. Their results were close to those of Yang et al., with a $13 \%$ reduction in the friability according to the incorporation of 5 wt\% of glass fibres. In comparison, adding the same amount of aramid fibres led to a strong $75 \%$ friability reduction and $81 \%$ when using 10 wt\% (Figure 35).

Another study of aramid fibres revealed the same tendency [57] as well as the importance of the chemical bonding between the fibres and the phenolic resin. The improvement of the friability with the introduction of aramid fibres can be enhanced by chemically modifying the surface of the fibres (Figure 36) to promote the adhesive bonding between them and the matrix. Hence, similar results were obtained with a lower content of the aramid fibres modified by sodium hydride and dimethylsulfoxide. Adding $8 \mathrm{wt} \%$ aramid fibres $(\mathrm{L}=3 \mathrm{~mm}, \mathrm{D}=12 \mu \mathrm{m})$ and $6 \mathrm{wt} \%$ of modified aramid fibres led to a significant $36 \%$ and $40 \%$ decrease in the friability, respectively.

Aramid fibres are the most efficient fibres to improve the friability and chemically modifying their surface may improve the performance further. Nevertheless, the formulation must be optimized in order to find the suitable amount of fibres to reach the minimal friability of the PF. 


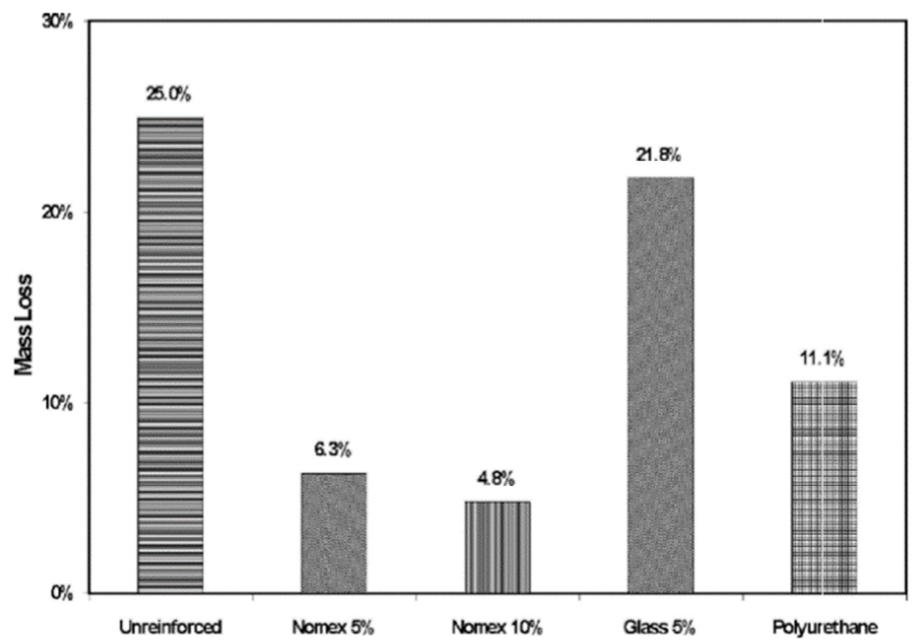

Figure 35. Friability test results for unreinforced phenolic foams, aramid and glass fibre reinforced foams and commercial polyurethane [10].

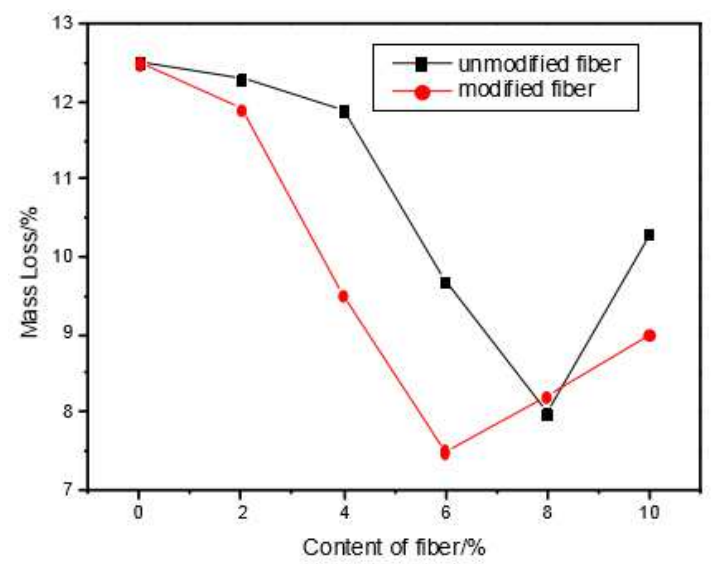

Figure 36. Variation of mass loss with aramid fibre and modified fibre, with by sodium hydride and dimethylsulfoxide, content [57].

Numerous types of particles have been studied, such as graphene and graphene oxide [33], MWCNT [36], silica [31], natural particles [61] and complex hybrids [30, 87]. Zhou et al. [33] demonstrated the importance of the interactions between the phenolic resin and the particles. In their study, they presented the modification of PF with 0.9 wt\% graphene and graphene oxide. Results showed a slight increase in the friability with the non-treated graphene whereas the graphene oxide decreased the friability by $30 \%$. The main difference between these two components is that graphene oxide contains functional groups such as $-\mathrm{OH}$ or $-\mathrm{COOH}$ that react with methyloxy groups of the phenolic resins.

Li et al. [82, 93] also reported that the flexible nitrile butadiene rubber powder (NBRP) can be chemically bonded to the phenolic resin and reported that the friability increased by $34 \%$ when 1 wt\% is added (Figure 37). 


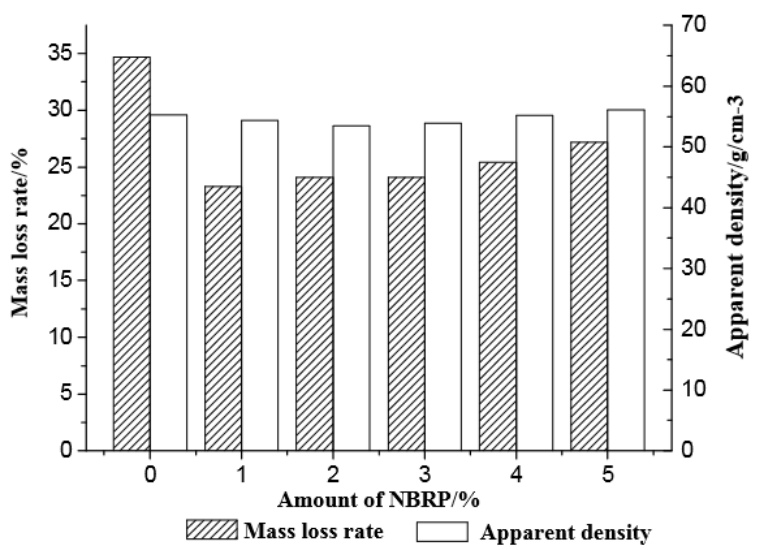

Figure 37. Relationship between the amount of NBRP and the brittleness properties of foams [82].

Li et al. [31] observed the influence of the interactions between particles and phenolic resin as well as the effect of the cell size on the friability. The addition of silica led to a reduction of the friability due to the crosslinking structure resulting from the reaction between silanols on silica surface and methyloxy groups in the phenolic resins. Moreover, the friability was reduced by $59 \%$ with only 2 wt\% of silica introduced.

In another study, Li et al. [36] pointed out the positive effect provided by the good dispersion of the particles embedded in the cell walls, with a $67 \%, 33 \%$ and $67 \%$ friability decrease with the addition of $0.5 \mathrm{wt} \%, 2 \mathrm{wt} \%$ and $5 \mathrm{wt} \%$ MWCNT ( $\mathrm{L}=10-30 \% \mathrm{~m}, \mathrm{D}=10-20 \mathrm{~nm})$, respectively. Nevertheless, no clear direction was given for the effect of the MWCNT amount on the friability. Best friability results were obtained with 0.5 and 5 wt\% MWCNT, whereas the best compressive strength was observed with 2 wt\% MWCNT, corresponding to the minimal friability reduction. Thus, a suitable number of particles must be incorporated according to the required final foam properties.

The aspect ratio was reported to play an important role in the friability in combination with the interactions and the cell density $[30,87]$. Authors have reported that graphene oxide can improve the friability of the foams up to $17 \%$ ( $4 \mathrm{phr}$ ) [30] and $23 \%$ (0.5 phr) [87], but do not give any information on the dimensions of the $G O$ sheets. The addition of silica ( $D=20 \mathrm{~nm}$ ) also seemed to decrease the friability by $38 \%$. Finally, their hybrid SGO decreased the friability value by $57 \%$ [87]. For the hybrid ZGO [30], the friability improved $68 \%$ whereas it increased $38 \%$ for $\alpha$-ZrP particles. The particles show a significant effect on friability; but once again, hybrids allow a synergetic effect between the particles. This effect may support the combination of a $\mathrm{GO}$ sheet covered by $\mathrm{SiO}_{2}$ nanospheres or $\alpha$-ZrP nanoparticles to create an original structure. 
Regarding natural particles, Del Saz Orozco et al. [61] described the opposite effect between the incorporation of lignin $(D=1.6 \mathrm{~mm})$ and wood flour $(D<0.15 \mathrm{~mm})$ particles. Regarding lignin particles, a 31\% friability reduction was reported with the introduction of $8.5 \mathrm{wt} \%$ lignin particles. This trend was due to lignin increasing the material toughness [61]. On the contrary, the higher wood flour particle weight fraction incorporated into PF, the greater the mass loss of the material. Indeed, authors mentioned that wood floor induces defects in the foam structure such as cracks, and thus the friability is deteriorated. The Figure 38 clearly exhibits the change of the shape of the foam specimens before and after friability tests in accordance with the measured mass losses.

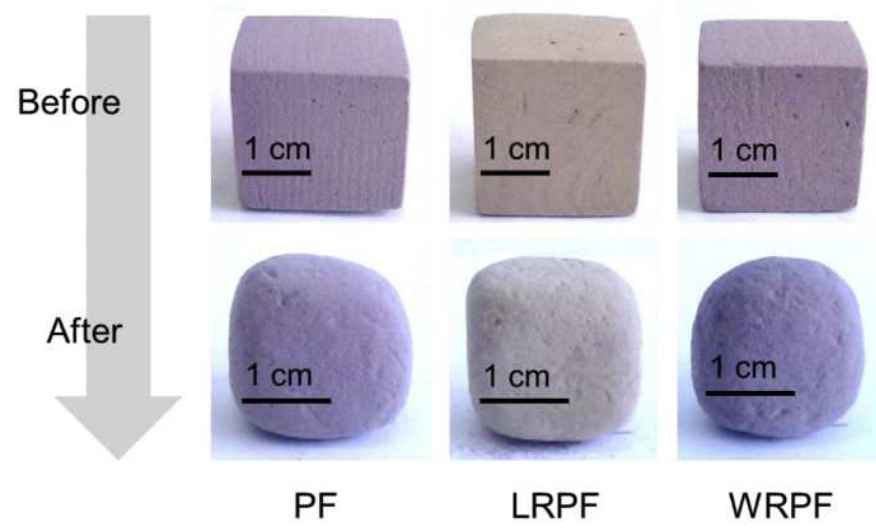

Figure 38. Friability test specimens before and after tests of unreinforced phenolic foams (PF), $8.5 \mathrm{wt} \%$ lignin particle (LRPF) and $8.5 \mathrm{wt} \%$ wood flour (WRPF) reinforced phenolic foams [61].

In conclusion, regarding aramid fibres and particles, covalent interactions with the resin matrix improve the friability and increase the load required to tear small parts of the foam. Moreover, aramid fibres offer a real potential for decreasing the friability since their poor stiffness allows the dissipation of energy through the micropeel process. The MWCNT can be embedded in the cell walls due to their nanometric size and protect the cell wall of PF. A summary of the friability properties of several reinforced PF is presented in Table 9.

Table 9. Friability of several reinforced phenolic foams.

\begin{tabular}{c|c|l|ll} 
Reference & $\begin{array}{c}\text { Density } \\
{\left[\mathrm{kg} \cdot \mathrm{m}^{-3}\right]}\end{array}$ & Foam type & \multicolumn{2}{|c}{ Friability } \\
\hline \multirow{2}{*}{$\begin{array}{c}\text { Shen et } \\
\text { al. [10] }\end{array}$} & \multirow{2}{*}{80} & $\mathrm{PF}]$ & 25.0 & $(100)$ \\
& & $\mathrm{PF}+5 \mathrm{wt} \%$ aramid fibres & 6.3 & $(25)$ \\
\hline Yu et al. & 70 & $\mathrm{PF}+5 \mathrm{wt} \%$ glass fibres & 4.8 & $(19)$ \\
\hline
\end{tabular}




\begin{tabular}{|c|c|c|c|c|}
\hline [57] & & $\begin{array}{l}\text { PF }+6 \text { wt } \% \text { modified aramid fibres } \\
\text { PF }+8 w t \% \text { non-modified aramid fibres }\end{array}$ & $\begin{array}{l}7.5 \\
8.0\end{array}$ & $\begin{array}{l}(60) \\
(64)\end{array}$ \\
\hline $\begin{array}{c}\text { Yang et al. } \\
\text { [98] }\end{array}$ & 65 & $\begin{array}{l}P F \\
P F+5 w t \% \text { glass fibres }\end{array}$ & $\begin{array}{l}27.0 \\
22.1\end{array}$ & $\begin{array}{l}(100) \\
(82)\end{array}$ \\
\hline $\begin{array}{l}\text { Li et al. } \\
\text { [30] }\end{array}$ & 16 & $\begin{array}{l}P F \\
P F+4 p h r Z G O \\
P F+4 p h r G O \\
P F+4 p h r \alpha-Z r P\end{array}$ & $\begin{array}{l}12.0 \\
5.1 \\
10.0 \\
6.4\end{array}$ & $\begin{array}{l}(100) \\
(43) \\
(83) \\
(53)\end{array}$ \\
\hline $\begin{array}{l}\text { Li et al. } \\
\text { [36] }\end{array}$ & 45 & $\begin{array}{l}P F \\
P F+0.5 w t \% \text { MWCNT } \\
P F+2 w t \% M W C N T \\
P F+5 w t \% \text { MWCNT }\end{array}$ & $\begin{array}{l}3 \\
1 \\
2 \\
1\end{array}$ & $\begin{array}{l}(100) \\
(33) \\
(67) \\
(33)\end{array}$ \\
\hline $\begin{array}{l}\text { Li et al. } \\
\text { [87] }\end{array}$ & 16 & $\begin{array}{l}\mathrm{PF} \\
\mathrm{PF}+1.5 \mathrm{phr} \mathrm{SGO} \\
\mathrm{PF}+0.5 \mathrm{phr} \mathrm{SiO2} \\
\mathrm{PF}+0.5 \mathrm{phr} \mathrm{GO}\end{array}$ & $\begin{array}{l}5.3 \\
1.7 \\
3.3 \\
4.1\end{array}$ & $\begin{array}{l}(100) \\
(32) \\
(62) \\
(77)\end{array}$ \\
\hline $\begin{array}{l}\text { Liu et al. } \\
\text { [90] }\end{array}$ & - & $\begin{array}{l}\mathrm{PF} \\
\mathrm{PF}+4 \mathrm{phr} \mathrm{Mg}-\mathrm{rGO}\end{array}$ & $\begin{array}{l}10.2 \\
2.9\end{array}$ & $\begin{array}{l}(100) \\
(28)\end{array}$ \\
\hline $\begin{array}{c}\text { Wang et al. } \\
\text { [92] }\end{array}$ & 40 & $\begin{array}{l}\mathrm{PF} \\
\mathrm{PF}+0.9 \mathrm{phr} \text { CoAl-LDH/GO }\end{array}$ & $\begin{array}{l}14.3 \\
6.4\end{array}$ & $\begin{array}{l}(100) \\
(45)\end{array}$ \\
\hline $\begin{array}{l}\text { Li et al. } \\
\text { [31] }\end{array}$ & 45 & $\begin{array}{l}\text { PF } \\
P F+2 w t \% \text { Silica sol }\end{array}$ & $\begin{array}{l}3.05 \\
1.26\end{array}$ & $\begin{array}{l}(100) \\
(41)\end{array}$ \\
\hline $\begin{array}{l}\text { Zhou et } \\
\text { al. [33] }\end{array}$ & 80 & $\begin{array}{l}\text { PF } \\
\text { PF + } 0.9 \text { wt } \% \text { graphene } \\
\text { PF + } 0.9 \text { wt } \% \text { graphene oxide }\end{array}$ & $\begin{array}{l}5.75 \\
6.02 \\
4.05\end{array}$ & $\begin{array}{l}(100) \\
(105) \\
(70)\end{array}$ \\
\hline $\begin{array}{l}\text { Li et al. } \\
\text { [82] }\end{array}$ & 55 & $\begin{array}{l}\mathrm{PF} \\
\mathrm{PF}+1 \mathrm{wt} \% \mathrm{NBRP}\end{array}$ & $\begin{array}{l}35 \\
23\end{array}$ & $\begin{array}{l}(100) \\
(66)\end{array}$ \\
\hline $\begin{array}{l}\text { Del Saz- } \\
\text { Orozco et } \\
\text { al. [61] }\end{array}$ & 120 & $\begin{array}{l}\text { PF } \\
\text { PF + 8.5 wt\% lignin particles } \\
\text { PF + 8.5 wt } \% \text { wood flour particles }\end{array}$ & $\begin{array}{l}32.2 \\
22.9 \\
41.8\end{array}$ & $\begin{array}{l}(100) \\
(69) \\
(130)\end{array}$ \\
\hline
\end{tabular}

() Changes relative to the reference sample (100\%)

\subsubsection{Reactive route}


The main method to decrease friability through chemical modification relies on the introduction of flexible chains in the backbone of the phenolic resin. Polyurethane and PEG demonstrated the ability to be deformed in PF, and thus the friability. Nevertheless, polyurethanes are reported to be more efficient.

Two studies reported the ability of polyurethane to decrease the friability of PF. In the first one, a significant $68 \%$ reduction was obtained by the addition of 5 wt\% isocyanate-terminated polyurethane prepolymer [98]. A schematic representation of the PF toughening mechanism is presented in Figure 39. In the second study, the addition of $5 \mathrm{wt} \%$ phosphorus and silicon-modified polyurethane prepolymer (PSPUP) [46] caused a $65 \%$ reduction of the friability.

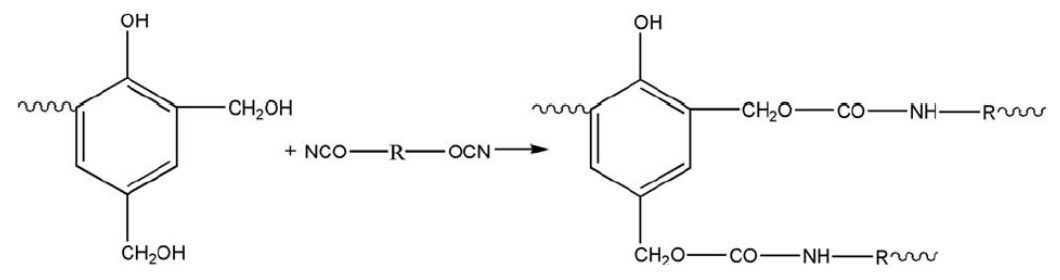

Figure 39. The schematic reaction of isocyanate function and phenolic resin [98].

Regarding PEG, Liu et al. [12] noticed that the long flexible polymer chains could increase the toughness of the foams and also reduce the crosslink density and decrease the brittleness. They observed upon the addition of 4.5 wt\% boric acid modified PEG that the friability values were reduced by $14 \%, 32 \%$ and $11 \%$ with the modified PEG 200,400 and 600 , respectively. Friability was quite improved with modified PEG 400, as along with the flexural and compressive strengths.

Finally, we consider that friability can be limited by introducing long and flexible chains that are chemically bonded to the phenolic resin. This mechanism will reduce the crosslinking density and the brittleness of the foams. However, reducing the crosslink density too much could lead to a degradation of the mechanical properties. Friability values of chemically modified foams are listed in Table 10

Table 10. Friability of several modified phenolic foams.

\begin{tabular}{|c|c|c|c|c|}
\hline Reference & $\begin{array}{l}\text { Density } \\
{\left[\mathrm{kg} \cdot \mathrm{m}^{-3}\right]}\end{array}$ & Foam type & [\%] & lity \\
\hline $\begin{array}{c}\text { Liu et al. } \\
\text { [12] }\end{array}$ & 25 & $\begin{array}{l}\text { PF } \\
P F+4.5 w t \% \text { PEG } 200 \text { BAE } \\
P F+4.5 w t \% \text { PEG } 400 \text { BAE } \\
P F+4.5 w t \% \text { PEG } 600 \text { BAE }\end{array}$ & $\begin{array}{l}3.3 .0 \\
2.85 \\
2.25 \\
2.95\end{array}$ & $\begin{array}{l}(100) \\
(86) \\
(68) \\
(89)\end{array}$ \\
\hline
\end{tabular}




\begin{tabular}{|c|c|c|c|c|}
\hline $\begin{array}{l}\text { Yang et } \\
\text { al. [46] }\end{array}$ & $\begin{array}{l}33 \\
60\end{array}$ & $\begin{array}{l}P F \\
P F+5 w t \% \text { PSPUP }\end{array}$ & $\begin{array}{l}5.0 \\
1.75\end{array}$ & $\begin{array}{l}(100) \\
(35)\end{array}$ \\
\hline $\begin{array}{c}\text { Hu et al. } \\
\text { [96] }\end{array}$ & - & $\begin{array}{l}\text { PF } \\
P F+8 \text { phr PEG/ } 4 \text { phr MPB }\end{array}$ & $\begin{array}{l}5.1 \\
1.5\end{array}$ & $\begin{array}{l}(100) \\
(30)\end{array}$ \\
\hline $\begin{array}{l}\text { Yang et } \\
\text { al. [98] }\end{array}$ & 65 & $\begin{array}{l}P F \\
P F+5 w t \% P U\end{array}$ & $\begin{array}{l}27.0 \\
8.7\end{array}$ & $\begin{array}{l}(100) \\
(32)\end{array}$ \\
\hline
\end{tabular}

() Changes relative to the reference sample (100\%)

In conclusion, aramid fibres present a real potential for decreasing the friability due to their poor stiffness that dissipates energy through the micropeel process. Regarding particles, the creation of covalent interactions with the resin matrix and the nucleating effect that favours the reduction of the cell size and the increase of the cell density decreases the friability. The MWCNT that are embedded in the cell walls due to their very low particle size reinforce the cell wall resistance of PF.

Friability can be also enhanced by chemical modification through the introduction of flexible chains that are chemically bonded to the rigid backbone of the phenolic resin. This pathway will reduce the crosslinking density and the brittleness of the foams. However, the reduction of the crosslink density must be controlled in order to limit the degradation of the mechanical resistance.

\section{Improving the fire properties of phenolic foams}

As mentioned before, PF exhibit excellent fire-retardant properties, such as low flammability, smoke density and toxicity of the flux gases during ignition. They are also considered to be no-dripping materials $[11,14,17]$. Their properties are due to the phenolic resin backbone chain that is mostly composed of benzene rings [59]. Unfortunately, the improvement of PF mechanical properties based on the addition of some flammable species or materials may dramatically decrease their fire properties, $[9,12]$. As a result, most studies are focused on the solutions that ensure the mechanical properties are improved through the additive and reactive routes without degrading the fire properties of modified PF.

The foam density plays a major role on the flame retardancy properties as it does on the mechanical properties. Increasing the density may favour the increase of the number of closed cells, modify the surface in contact with the flame or reduce the oxygen ratio available in the foam, and thus modify the foam flame retardancy behaviour. 
Fire behaviour can be described through three major parameters, namely ignitability, contribution to flame spread and heat release. Two main tests are used to investigate the PF fire behaviour. They are the limiting oxygen index determination and cone calorimeter test. Depending on the application field, some specific tests are implemented in order to simulate the operating conditions.

\subsection{Limiting oxygen index}

The limiting oxygen index (LOI), also known as the Oxygen Index (OI), is a simple heat ignition test, according to ISO 4589 [100]. It evaluates the relative flammability of a material, its ignitability and inflammation. In this test, the sample is fixed vertically from the bottom in a glass cylinder chamber in a controlled oxygen-nitrogen atmosphere. The LOI value corresponds to the minimal oxygen concentration required to sustain the combustion of the material and is expressed as the oxygen percentage in an oxygen-nitrogen mixture. Hence, the higher the LOI value, the better the fire retardancy of the material. The LOI values are usually lower than $22 \%$ for flammable materials, between $22 \%$ and $27 \%$ for combustible materials and higher than $27 \%$ for flame retardant materials [38]. With LOI values ranging from $28.5 \%$ to $52 \%$, PF are classified as non-flammable materials. Thus, increasing their initial values significantly remains a challenge, especially when the final mechanical properties could be impacted. Nevertheless, the improvement is mainly realized by the introduction of non-flammable particles [41], the introduction of a flame retardant system [38] or by chemical modification with $\mathrm{P}, \mathrm{N}$ or $\mathrm{B}[83]$.

\subsubsection{Additive route by addition of inorganic fibres and particles}

It is well known that the use of flame retardant systems (FR) increases the LOI value. However, in order to reach the targeted fire retardancy properties, theses additives are often introduced in significant amounts that concurrently decrease the material mechanical properties. Thus, a suitable balance must be found between the FR amounts and the final mechanical properties of the material. It is noteworthy that the LOI value may be artificially inflated by the addition of a significant FR amount that decreases the concentration of the combustible material.

Per literature, improving PF LOI values upon the addition of fillers often relies on the reduction of the oxygen permeability $[12,41,101]$ and the formation of an efficient barrier at the PF surface due to the formation of a more compact charred layer $[30,41,87,101]$.

Ma et al. [38] provide an example of increasing PF fire properties to the detriment of their mechanical properties. Their flame-retardant system that was introduced to the formulation had a

very effective on LOI. A synergistic effect was observed between zinc oxide, ammonium 
polyphosphate (15 wt\%) and pentaerythritol (5 wt\%). In fact, LOI values observed an outstanding increase of $83 \%$ and $80 \%$ when adding only 0.5 and $1 \mathrm{wt} \%$ of zinc oxide in the FR system, respectively. Unfortunately, the final foams showed decreased compressive and flexural strengths of 26 and $27 \%$, respectively, due to the high amount of additives. In another study, they success to maintain LOI stable by adding modified wood fibres although wood fibres are flammable [85].

Whereas some published studies report an improvement of the LOI value while decreasing the compressive and flexural strengths [38], some authors provide very promising solutions that improve fire and mechanical properties. Li et al. studied the influence of silica-graphene oxide (SGO) [87] and alpha zirconium phosphate/graphene oxide (ZGO) [30] hybrid systems on the PF LOI values. They observed that the foam LOI values were slightly increased by $1 \%$ and $5 \%$ with increasing graphene oxide amount, from 0.5 to $4 \mathrm{phr}$, respectively. A 1\% LOI increase was obtained by the addition of 0.5 phr silica and the mixture with GO [87], whereas 0.5 phr SGO hybrid induced 4\% LOI increase. These results point out to the higher efficiency of silica-graphene oxide mixture. The LOI values may be further increased by increasing SGO content: LOI increased by 7\% upon the addition of 2 phr SGO. However, enhanced fire and mechanical properties were obtained with an optimum amount of 1.5 phr SGO. The authors reported the same trends in a second study [30]. The balance between fire and mechanical properties improvement was observed with the addition of $4 \mathrm{phr}$ ZGO. More recently, Liu and Wang [90] showed that reduced graphene oxide hybrids were promising solutions for the improvement of flame retardant properties of phenolic foams, Furthermore Wang and Li [92] came to the same conclusion in terms of thermal stability.

The addition of 1 and $2 \mathrm{wt} \%$ titanium nitride nanoparticles $(30 \mathrm{~nm}$ ) [41] also increases the LOI value of PF by $14 \%$ and $19 \%$, respectively. Niu et al. [101] showed that the addition of $3 \%$ of organomodified montmorillonite (OMMT) increased the LOI value by $3 \%$. Beside the positive effects of some fillers as FR, Yuan et al. [45] reported a 7\% decrease of LOI value with the addition of $0.12 \mathrm{phr}$ poly(n-butyl acrylate)/Silica core-shell particles, without explaining these results.

Finally, we observed that adding a FR strongly increased the PF LOI value. Moreover, SGO and ZGO hybrids also provide a slight improvement. An exhaustive list of reinforced PF and their LOI values are listed in Table 11.

Table 11. LOI values of several reinforced phenolic foams.

\begin{tabular}{l|l|l|l} 
Reference & Density & Foam type & LOI \\
\hline
\end{tabular}




\begin{tabular}{|c|c|c|c|c|}
\hline & {$\left[\mathrm{kg} \cdot \mathrm{m}^{-3}\right]$} & & [\%] & \\
\hline $\begin{array}{l}\text { Ma et al. } \\
\text { [85] }\end{array}$ & - & $\begin{array}{l}\text { PF } \\
P F+4 w t \% \text { modified wood fibres }\end{array}$ & $\begin{array}{l}34.5 \\
34.5\end{array}$ & $\begin{array}{l}(100) \\
(100)\end{array}$ \\
\hline $\begin{array}{l}\text { Li et al. } \\
\text { [30] }\end{array}$ & 16 & $\begin{array}{l}\mathrm{PF} \\
\mathrm{PF}+4 \mathrm{phr} Z \mathrm{GO} \\
\mathrm{PF}+4 \mathrm{phr} \mathrm{GO} \\
\mathrm{PF}+4 \mathrm{phr} \alpha-\mathrm{ZrP}\end{array}$ & $\begin{array}{l}38.0 \\
42.0 \\
40.0 \\
41.5\end{array}$ & $\begin{array}{l}(100) \\
(111) \\
(105) \\
(109)\end{array}$ \\
\hline $\begin{array}{l}\text { Li et al. } \\
\text { [41] }\end{array}$ & 42 & $\begin{array}{l}\mathrm{PF} \\
\mathrm{PF}+1 \mathrm{wt} \% \text { titanium nitride nanoparticles } \\
\mathrm{PF}+2 \mathrm{wt} \% \text { titanium nitride nanoparticles }\end{array}$ & $\begin{array}{l}28.5 \\
32.5 \\
34.0\end{array}$ & $\begin{array}{l}(100) \\
(114) \\
(119)\end{array}$ \\
\hline $\begin{array}{l}\text { Li et al. } \\
\text { [87] }\end{array}$ & 16 & $\begin{array}{l}\text { PF } \\
P F+0.5 \text { phr SGO } \\
P F+2 \text { phr SGO } \\
P F+0.5 \mathrm{phr} \mathrm{SiO2} \\
P F+0.5 \mathrm{phr} \text { GO }\end{array}$ & $\begin{array}{l}38.0 \\
39.5 \\
41.0 \\
38.5 \\
38.5\end{array}$ & $\begin{array}{l}(100) \\
(104) \\
(108) \\
(101) \\
(101)\end{array}$ \\
\hline $\begin{array}{l}\text { Liu et al. } \\
\text { [90] }\end{array}$ & - & $\begin{array}{l}\mathrm{PF} \\
\mathrm{PF}+4 \mathrm{phr} \mathrm{Mg}-\mathrm{rGO}\end{array}$ & $\begin{array}{l}38.0 \\
41.5\end{array}$ & $\begin{array}{l}(100) \\
(109)\end{array}$ \\
\hline $\begin{array}{l}\text { Wang et al. } \\
\text { [92] }\end{array}$ & 40 & $\begin{array}{l}\mathrm{PF} \\
\mathrm{PF}+0.9 \mathrm{phr} \mathrm{CoAl}-\mathrm{LDH} / \mathrm{GO}\end{array}$ & $\begin{array}{l}38 \\
39\end{array}$ & $\begin{array}{l}(100) \\
(103)\end{array}$ \\
\hline $\begin{array}{l}\text { Ma et al. } \\
\text { [38] }\end{array}$ & 50 & $\begin{array}{l}\mathrm{PF} \\
\mathrm{PF}+0.5 \% \mathrm{ZnO} \\
\mathrm{PF}+1 \% \mathrm{ZnO}\end{array}$ & $\begin{array}{l}41.0 \\
75.0 \\
74.0\end{array}$ & $\begin{array}{l}(100) \\
(183) \\
(180)\end{array}$ \\
\hline $\begin{array}{l}\text { Yuan et } \\
\text { al. [45] }\end{array}$ & 25 & $\begin{array}{l}\text { PF } \\
\text { PF }+0.03 \text { phr PBA/Silica core-shell particles } \\
\text { PF }+0.12 \text { phr PBA/Silica core-shell particles }\end{array}$ & $\begin{array}{l}38.2 \\
38.0 \\
35.5\end{array}$ & $\begin{array}{l}(100) \\
(100) \\
(93)\end{array}$ \\
\hline $\begin{array}{c}\text { Niu et al. } \\
\text { [101] }\end{array}$ & - & $\begin{array}{l}\mathrm{PF} \\
\mathrm{PF}+3 \% \text { organo modified montmorillonite }\end{array}$ & $\begin{array}{l}36.1 \\
37.3\end{array}$ & $\begin{array}{l}(100) \\
(103)\end{array}$ \\
\hline $\begin{array}{l}\text { Yuan et } \\
\text { al. [47] }\end{array}$ & 50 & $\begin{array}{l}\mathrm{PF} \\
\mathrm{PF}+0.5 \mathrm{wt} \% \text { glass fibres }+10 w t \% \text { modified PU }\end{array}$ & $\begin{array}{l}52.0 \\
41.0\end{array}$ & $\begin{array}{l}(100) \\
(89)\end{array}$ \\
\hline
\end{tabular}

() Changes relative to the reference sample (100\%)

\subsubsection{Reactive route}


The most common flame retardants are phosphorous-based compounds. Upon heating, they generate phosphorous acids that capture the free radicals in the combustion phase, interrupt the combustion and accelerate the charring process $[102,103]$. Thus, phosphorus compounds, alone or in combination with other elements, such as $\mathrm{Si}$ or $\mathrm{N}$, have been tested and are reported hereafter. Most often, these elements are added through the reaction of modified PEGs and polyurethanes with phenolic resins, since the major aim of the chemical modification is the improvement of the mechanical properties $[12-14,59]$. Nevertheless, PU is a combustible material and PEG is flammable. It therefore appeared very difficult to keep the fire resistance level of neat PF for PEG or polyurethane-modified PF.

Polyethylene glycols are considered quite flammable due to the polyether molecular chains $[12,14$, 59]. Hence, authors have reported, as expected, a decrease of about $19 \%$ in LOI values with the addition of $11 \mathrm{wt} \%$ of neat polyethylene glycol [14]. Nevertheless, several authors tried to develop a chemical modification of PEG with P or B atoms [12] to balance the PEG flammability. Yang et al. [59] used two phosphorus modified PEGs. Results revealed that the higher the PPEG amount, the lower the foam LOI value. In fact, LOI values were reduced by $21 \%$ and $12 \%$ by incorporating 10 wt\% PPEG 400 and 600 , respectively. Moreover, they explained that LOI values of modified foams with phosphorus-PEG 600 are always higher than those of foams modified with PPEG 400 at the same loading. This is due to the flammability of the polyether molecular chains although after modification, they contain phosphorus elements.

Whereas the addition of $4.5 \mathrm{wt} \%$ of neat polyethylene glycol 400 led to a drastic $17 \%$ reduction of the LOI value, 4.5 wt\% B modified polyethylene glycol 400 reduced the LOI value only by $5 \%$. Moreover, the authors [12] pointed out that the LOI decreased by 4,5 and $12 \%$ for PF containing boron-modified PEG 200, 400 and 600, respectively. The difference was attributed to the B content in each PEG. The highest B content was in the modified PEG 200, for an equivalent mass, due to its shorter chain length in comparison with PEG 400 and 600. Thus, the PEG flammability was almost compensated for due to the presence of $B$ elements.

To our best knowledge, Sui et al. [13] are the only authors that reported an enhancement with PEG (Figure 40). The introduction of $6 \mathrm{wt} \%$ phosphate-modified PEG 200, 400 and 600 led to a significant increase in the LOI by $36 \%, 28 \%$ and $14 \%$, respectively. The authors reasoned that this is because the chain length of PEGP 200 is the shortest, and thus the phosphorus content of PEGP200 was higher than that of the other two at the same amount. 
Nevertheless, no reason has been found to explain the difference in behaviour observed between the Yang and Sui studies.

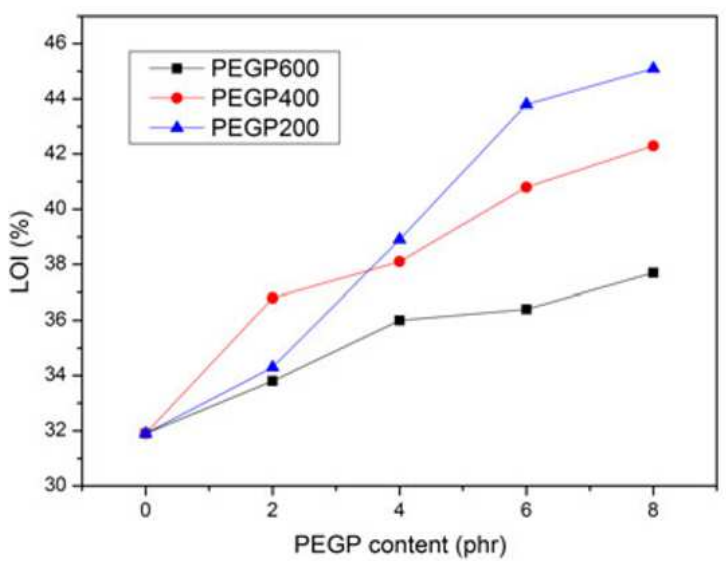

Figure 40. Effect of PEGP content on the LOI of the toughened phenolic foams [13].

Yuan et al. [47] introduced a phosphorous-containing polyurethane prepolymer (DOPO-based compound) to the phenolic resin. A phosphorus-based compound (methyl-DOPO) was already studied for improving the flame retardancy of polyurethane foams [104]. As expected, the introduction of $10 \mathrm{wt} \%$ phosphorous-modified PU decreased the LOI value by $11 \%$ due to the presence of P. Yang et al. [46] searched for a synergistic effect by combining P and Si. The phosphorus and silicon-containing polyurethane prepolymer (PSPUP) used is illustrated in Figure 28. The LOI value increased by $4 \%$ with the addition of $3 \mathrm{wt} \%$ of PSPUP, which was also the case for the compressive strength value. However, an additional amount of PSPUP, up to $5 \mathrm{wt} \%$, reduced the LOI value by about $3 \%$. Although the methyl groups of polysiloxane are flammable, P and Si provide the PSPUP agent good fire retardance and improve the PF flame retardancy.

In Ding et al. [83], $\mathrm{P}$ and $\mathrm{N}$ were combined to modify polyurethane. The LOI increased by $4 \%$ with the addition of $3 w t \%$ modified PU. A further increase to $8 w t \%$ induced a significant $21 \%$ increase in the LOI. This important enhancement was attributed to the synergistic effect between the $P$ and $N$ elements because $\mathrm{N}$-compounds may act as a gas source and produce non-flammable gases. These non-flammable gases may dilute the flammable gas concentration and retard the decomposition of the PF.

Finally, the LOI values for the dicyandiamide that improved the compressive strength as a chemical phenolic resin modification agent were investigated [95]. The incorporation of 4 and $8 w t \%$ dicyandiamide slightly increased the LOI values $(<2 \%)$. This result was attributed to the nonflammable nature of the dicyandiamide due to the presence of $\mathrm{N}$. 
In conclusion, besides their mechanical property enhancements, polyethylene glycols and polyurethanes are not suitable for improving the fire retardancy of PF, although modified-PU performance was higher than modified-PEG ones. Phosphorous-based compounds are the most efficient for increasing PF LOI values, especially in combination with nitrogen elements. The LOI values of the reported PF are presented in Table 12.

Table 12. LOI values of several modified phenolic foams.

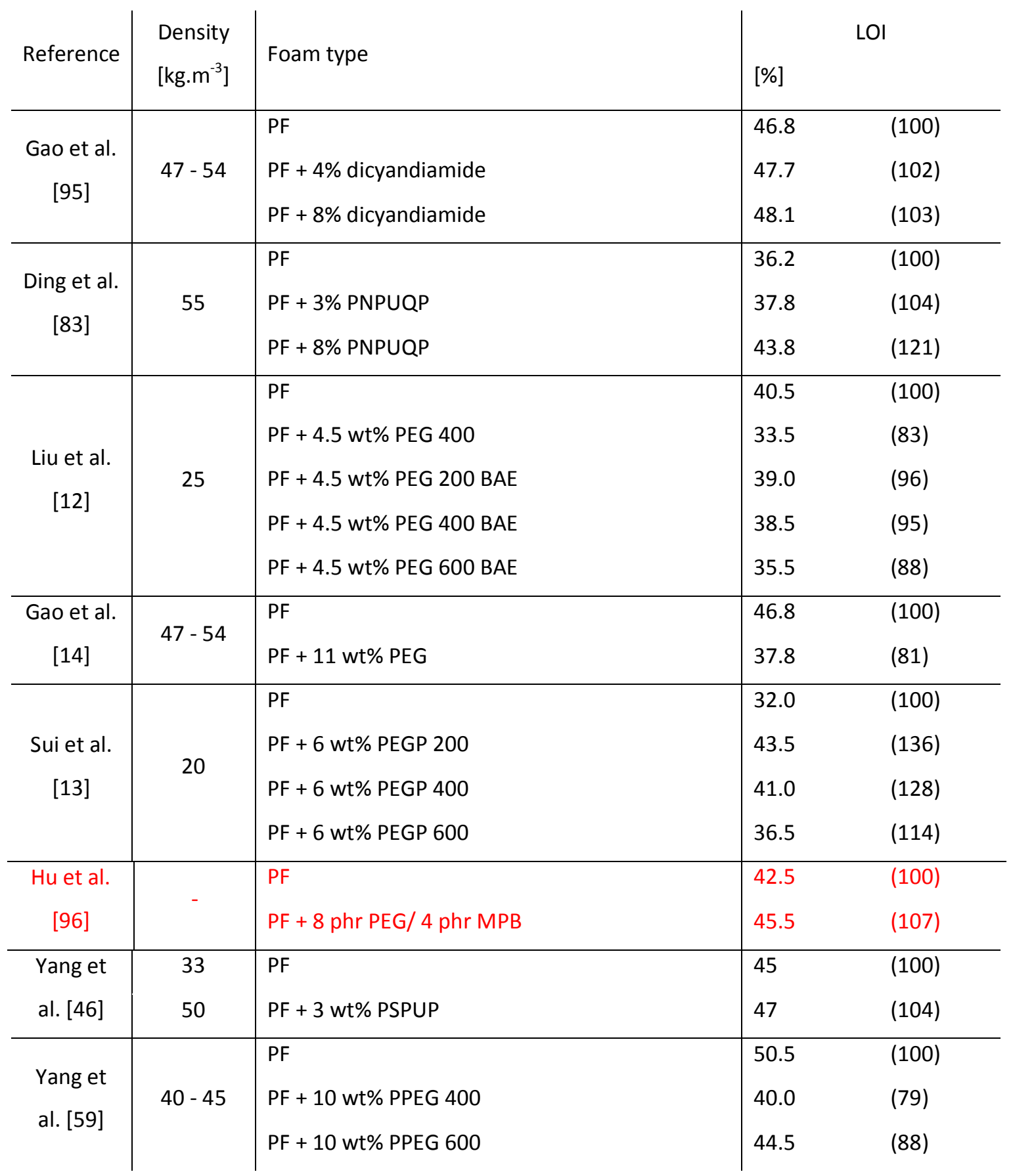


() Changes relative to the reference sample (100\%)

\subsection{Peak heat release rate measurement}

The cone calorimeter is widely used to investigate the combustion behaviour of materials. It evaluates the reaction of a material to fire, i.e. its contribution to fire when subjected to thermal aggression. The fire conditions are simulated at bench scale and the energy is provided by the radiative spirals of the cone calorimeter, which can be adjusted from a few kilowatts to 100 kilowatts per square meter. Different energy levels are used, such as illuminations of $35 \mathrm{~kW} \cdot \mathrm{m}^{-2}$ (start of fire), $50 \mathrm{~kW} \cdot \mathrm{m}^{-2}$ (advanced stage of development) and $75 \mathrm{~kW} \cdot \mathrm{m}^{-2}$ (fully developed fire). Experiments are carried out under constant irradiance $\left(\mathrm{kW} . \mathrm{m}^{-2}\right)$ and different data are collected, such as time to ignition, effective heat of combustion, heat release rate, smoke release. Heat release rate (HRR) can be viewed as the engine driving the fire; it is a critical parameter in determining the hazard from a fire. The peak of heat release rate (pHRR) represents the maximum value of HRR. The HRR is calculated from the oxygen consumption according to the Huggett principle [55] for which he heat of combustion of organic compounds is proportional to the amount of oxygen required by the combustion (i.e. $13.1 \mathrm{~kJ} . \mathrm{g}^{-1}$ of oxygen consumed).

Neat PF have low HRR values (below $50 \mathrm{~kW} \cdot \mathrm{m}^{-2}$, under a $35 \mathrm{~kW} \cdot \mathrm{m}^{-2}$ external heat flux), indicating that they release a very small amount of heat during combustion. Hence it is challenging to significantly reduce their HRR values further. However, decreasing the PF heat release during combustion is mainly realized by avoiding the exchange between the flame and the material. The char formation plays the role of a barrier between the foam and the flaming surroundings and is thus the most efficient mechanism in the fire retardancy or/and resistance.

\subsubsection{Additive route by addition of inorganic particles}

Few studies have been published on the increase of HRR and pHRR values, probably because LOI values are more commonly used in industry for the evaluation of fire material properties. Usually, particles are used to form a denser char layer that will protect the rest of the material. Moreover, a product-like char formation can be used to increase significantly the thickness of the char layer.

Li et al. $[30,87]$ presented the cone calorimeter results on their SGO and ZGO hybrids tested with a heat flux of $35 \mathrm{~kW} \cdot \mathrm{m}^{-2}$. They correlated all the flame-retardant properties of their materials and reached the conclusion that high cell density coupled to a small cell size provided by an appropriate amount of ZGO allowed the formation of a dense charred layer during combustion. Nanoparticles can cover this surface and protect the foam from thermal decomposition at higher temperatures 
leading to the formation of a more compact char layer. A synergistic effect was observed when using $\alpha$-ZrP and GO. As for ZGO systems, the silica effect was predominant and no synergistic effect was reported about its addition to GO.

Both studies revealed that pHRR values decreased by 6 and $22 \%$ with an increasing graphene oxide amount from 0.5 to $4 \mathrm{phr}$, respectively, pointing out the positive effect of graphene oxide [87], The authors compared the effect of both $0.5 \mathrm{phr}$ silica and SGO addition and observed a pHRR decrease of $26 \%$ and $5 \%$ with silica and SGO, respectively, confirming the silica performance to improve cone calorimeter results. Nevertheless, the $1.5 \mathrm{phr}$ addition of SGO that corresponded to the optimal amount for improving LOI and mechanical properties, induced the $21 \% \mathrm{pHRR}$ decrease. For the second study on ZGO [30], at an equivalent amount of $4 \mathrm{phr}, \mathrm{GO}$ decreased the PF pHRR value by $22 \%$ while $\alpha$-ZrP decreased the value by $14 \%$. However, the hybrid ZGO added at $4 \mathrm{phr}$ decreased the value by $25 \%$ and was comparable to $\mathrm{GO}$. Comparable results were obtained using graphene oxide hybrids particles as already discussed in ref [90, 92].

Ma et al. [38] tested their modified foam under $50 \mathrm{~kW} \cdot \mathrm{m}^{-2}$ of irradiance, which corresponded to the most used heat flux for studying fire-retardant behaviour. Thanks to the synergetic effect of the FR, i.e. the flame-retardant agent, char forming agent and $\mathrm{ZnO}$, they strongly decreased the pHRR by $66 \%$ and $7 \%$ with an addition of 0.5 and 1 wt $\%$ of $\mathrm{ZnO}$, respectively. This system provided very significant results on the flammability and the fire behaviour of modified PF. However, it did not maintain the foam mechanical properties, as the compressive and flexural strengths decreased by $26 \%$ and $27 \%$, respectively.

The PHRR measured on several reinforced PF are listed in Table 13.

Table 13. pHRR value of several reinforced phenolic foams.

\begin{tabular}{c|c|l|ll}
$\begin{array}{c}\text { Referen } \\
\text { ce }\end{array}$ & $\begin{array}{c}\text { Density } \\
{\left[\mathrm{kg} \cdot \mathrm{m}^{-3}\right]}\end{array}$ & Foam type & \multicolumn{2}{|c}{ PHRR } \\
\hline $\left.\mathrm{kW} \cdot \mathrm{m}^{-2}\right]$
\end{tabular}




\begin{tabular}{|c|c|c|c|c|}
\hline & & $\begin{array}{l}\mathrm{PF}+1.5 \mathrm{phr} \mathrm{SGO} \\
\mathrm{PF}+0.5 \mathrm{phr} \mathrm{SiO} 2 \\
\mathrm{PF}+0.5 \mathrm{phr} \mathrm{GO}\end{array}$ & $\begin{array}{l}21.7 \\
20.3 \\
26.0\end{array}$ & $\begin{array}{l}(79) \\
(74) \\
(94)\end{array}$ \\
\hline $\begin{array}{l}\text { Liu et al. } \\
\text { [90] }\end{array}$ & - & $\begin{array}{l}\mathrm{PF} \\
\mathrm{PF}+4 \text { phr Mg-rGO }\end{array}$ & $\begin{array}{l}48.8 \\
34.8\end{array}$ & $\begin{array}{l}(100) \\
(72)\end{array}$ \\
\hline $\begin{array}{l}\text { Wang et } \\
\text { al. [92] }\end{array}$ & 40 & $\begin{array}{l}\mathrm{PF} \\
\mathrm{PF}+0.9 \mathrm{phr} \text { CoAl-LDH/GO }\end{array}$ & $\begin{array}{l}52.3 \\
48.0\end{array}$ & $\begin{array}{l}(100) \\
(92)\end{array}$ \\
\hline $\begin{array}{c}\text { Ma et al. } \\
\text { [38] }\end{array}$ & 50 & $\begin{array}{l}P F \\
P F+0.5 \% Z n O \\
P F+1 \% Z n O\end{array}$ & $\begin{array}{l}30.4 \\
10.4 \\
6.8\end{array}$ & $\begin{array}{l}(100) \\
(34) \\
(22)\end{array}$ \\
\hline
\end{tabular}

() Changes relative to the reference sample (100\%)

\subsubsection{Reactive route}

The concept of the studies aiming to improve the behaviour during the cone calorimeter test through chemical pathways relies on the introduction of chemical species, usually $P$, in the phenolic backbone. The chemical species will modify the formed char layer that forms a barrier and limit the heat and mass transfers between the material and the flame [12]. The nature and the amount of the species are logically important parameters to be controlled.

Liu et al. [12] demonstrated the positive effect of $B$ that induced the increase of the char layer thickness. The addition of 4.5 wt\% PEG 400 resulted in a strong increase in pHRR value of $38 \%$. In addition, the authors studied the effects of the addition of boron-modified PEG 200, 400 and 600 and observed that only boron-modified PEG 400 reduced pHRR by $10 \%$, whereas pHRR values increased with boron-modified PEG $(200,600)$. No information was given to explain this phenomenon, but SEM images on specimens after testing confirmed the role of the char layer thickness.

Yang et al. [59] highlighted the P efficiency on the fire-retardant behaviour of modified-PF by using a micro-scale cone calorimeter (MCC). Results showed a significant $42 \%$ decrease in pHRR with the addition of 10 wt\% PPEG 600 (Figure 23). They explained this result by the increase of heat release restraining that occurred due to the increasing $\mathrm{P}$ content.

Sui et al. results [13] about PPEG confirmed those obtained by Yang. The addition of 6 wt\% phosphates PEG 200 induced the pHRR decrease by $28 \%$ while modified PEG 400 and 600 pHRR 
values showed a pHRR increase of 7 and $11 \%$, respectively. Taking into consideration that the $P$ content per PEG weight unit is higher for a low molar mass PEG because the chain length is shorter, pHRR values are consistent with the P content in the foams. While dicyandiamide [95] exhibited some efficiency to increase LOI value of PF, it also allowed to decrease pHRR value by $19 \%$ upon the addition of $4 \%$. PHRR values of chemically modified foams are listed in Table 14.

Table 14. pHRR of several modified phenolic foams.

\begin{tabular}{|c|c|c|c|c|}
\hline Reference & $\begin{array}{l}\text { Density } \\
{\left[\mathrm{kg} \cdot \mathrm{m}^{-3}\right]}\end{array}$ & Foam type & \multicolumn{2}{|c|}{$\left[\mathrm{kW} \cdot \mathrm{m}^{-2}\right]$} \\
\hline $\begin{array}{c}\text { Gao et al. } \\
\text { [95] }\end{array}$ & $47-54$ & $\begin{array}{l}\mathrm{PF} \\
\mathrm{PF}+4 \% \text { dicyandiamide }\end{array}$ & $\begin{array}{l}91 \\
73\end{array}$ & $\begin{array}{l}(100) \\
(81)\end{array}$ \\
\hline $\begin{array}{l}\text { Liu et al. } \\
\text { [12] }\end{array}$ & 25 & $\begin{array}{l}P F \\
P F+4.5 w t \% \text { PEG } 200 \text { BAE } \\
P F+4.5 w t \% \text { PEG } 400 \text { BAE } \\
P F+4.5 w t \% \text { PEG } 600 \text { BAE }\end{array}$ & $\begin{array}{l}39 \\
43 \\
35 \\
56\end{array}$ & $\begin{array}{l}(100) \\
(110) \\
(90) \\
(144)\end{array}$ \\
\hline $\begin{array}{l}\text { Sui et al. } \\
\text { [13] }\end{array}$ & 20 & $\begin{array}{l}P F \\
P F+6 w t \% \text { PEGP } 200 \\
P F+6 w t \% \text { PEGP } 400 \\
P F+6 w t \% \text { PEGP } 600\end{array}$ & $\begin{array}{l}46 \\
33 \\
49 \\
51\end{array}$ & $\begin{array}{l}(100) \\
(72) \\
(107) \\
(111)\end{array}$ \\
\hline $\begin{array}{c}\text { Hu et al. } \\
\text { [96] }\end{array}$ & - & $\begin{array}{l}\mathrm{PF} \\
\mathrm{PF}+8 \mathrm{phr} \mathrm{PEG} / 4 \mathrm{phr} \mathrm{MPB}\end{array}$ & $\begin{array}{l}39 \\
46\end{array}$ & $\begin{array}{l}(100) \\
(118)\end{array}$ \\
\hline $\begin{array}{l}\text { Yang et } \\
\text { al. [59] }\end{array}$ & $40-45$ & $\begin{array}{l}P F \\
P F+10 w t \% \text { PPEG } 600\end{array}$ & $\begin{array}{l}53 \\
31\end{array}$ & $\begin{array}{l}(100) \\
(58)\end{array}$ \\
\hline
\end{tabular}

() Changes relative to the reference sample (100\%)

To conclude, increasing the layer thickness and density ensures better fire-retardant properties, depending on the chemical modification of the PF or the added fillers. The efficiency of flameretardant systems depends on their nature and the added amount. Significant loads can cause dramatic mechanical failures. The combination of various nanoparticles may induce a synergistic effect by increasing the layer thickness and char density. Regarding PF chemical modification, the introduction of B compensates the PEG flammability effect on PF, whereas or P-compounds ensure the pHRR decrease of PF, mainly by increasing the thickness of the char layer. 


\section{New trends towards green chemistry}

Nowadays the rising cost, foreseeable future scarcity of petrochemicals and sustainable development concerns support the development of environmental-friendly and renewable bio-sourced materials [105]. The development of PF is not impervious to these trends. The replacement possibilities of petroleum resources based phenol and formaldehyde are reported in the literature. In this review, no studies on the replacement of the formaldehyde will be discussed, but some literature exists on this topic $[106,107]$.

Forest and agricultural lignocellulosic biomasses, such as wood [108,109] and bark [110] are being considered as potential alternatives. Lignin, the second most abundant renewable biopolymer on Earth contains some phenolic functional groups and may replace phenol in the synthesis of phenolicbased resins $[105,111]$.

The development of bio-based phenol PF requires the investigation of green routes and techniques while keeping global environment protection of prime importance. Among biochemical or thermochemical conversion technologies developed in the past few decades, direct liquefaction of biomass in the presence of water, organic solvents like alcohols, or supercritical fluids has been considered as a promising route with high biomass conversion for the production of bio-based phenolic resins with comparable properties to conventional PF resins, i.e. low molar mass phenolic products at high substitution ratio $[110,112,113]$.

Lee et al. [109] produced PF from liquefied phenolated wood. The liquefaction was obtained at 150 ${ }^{\circ} \mathrm{C}$ and used sulfuric acid as catalyst [114]. The product was then allowed to react with formaldehyde under low alkali conditions at $70{ }^{\circ} \mathrm{C}$ for 2 hours to form the wood-based resol-type phenolic resin. Foaming was performed with diisopropyl ether $\left(B_{p}=68.4^{\circ} \mathrm{C}\right)$ as a blowing agent because of the high reaction temperature (exothermic reaction) given by the high reactivity of liquefied wood-based resol resin, which limits the use of n-pentane. Polyoxyethylene sorbitan monopalmitate as surfactant and hydrochloric acid catalyst were introduced to the formulation. The final foam density was 0.032 and presented a compressive strength of $96 \mathrm{kPa}$ compared to a conventional foam with a density of 0.017 and compressive strength of $49 \mathrm{kPa}$. Due to the high viscosity of the wood-based resol resin, the authors tried to mix conventional and modified resins in order to reduce the viscosity and reach a lower foam density. The final foam density decreased to 0.019 , but the compressive strength was lower than that for conventional foams (25 $\mathrm{kPa})$.

Zhuang et al. [111] produced conventional resol resin and modified resol resins containing 10, 20, 30 and $40 \mathrm{wt} \%$ of lignin. Then, the surfactant Tween 80, cyclopentane as a blowing agent, and 
hydrochloric and phosphoric acids as catalysts were added to the mixture. The foam was cured at 50 ${ }^{\circ} \mathrm{C}$. They obtained foam with a density of 0.043 . The Figure 41 presents the lignin content effect on compressive and flexural strengths, and it clearly shows that the mechanical properties decreased with increasing lignin content. Moreover, the bio-sourced foams presented a more irregular cell structure, with a broader size distribution and larger mean cells size, that explains the reduced mechanical properties. In addition, the critical oxygen value decreased from $56 \%$ to $53.5 \%$ and $51 \%$ upon the addition of $10 \mathrm{wt} \%$ and $20 \mathrm{wt} \%$ of lignin respectively. However, increasing the lignin up to 30 and $40 \mathrm{wt} \%$ induced no changes in the critical oxygen values.
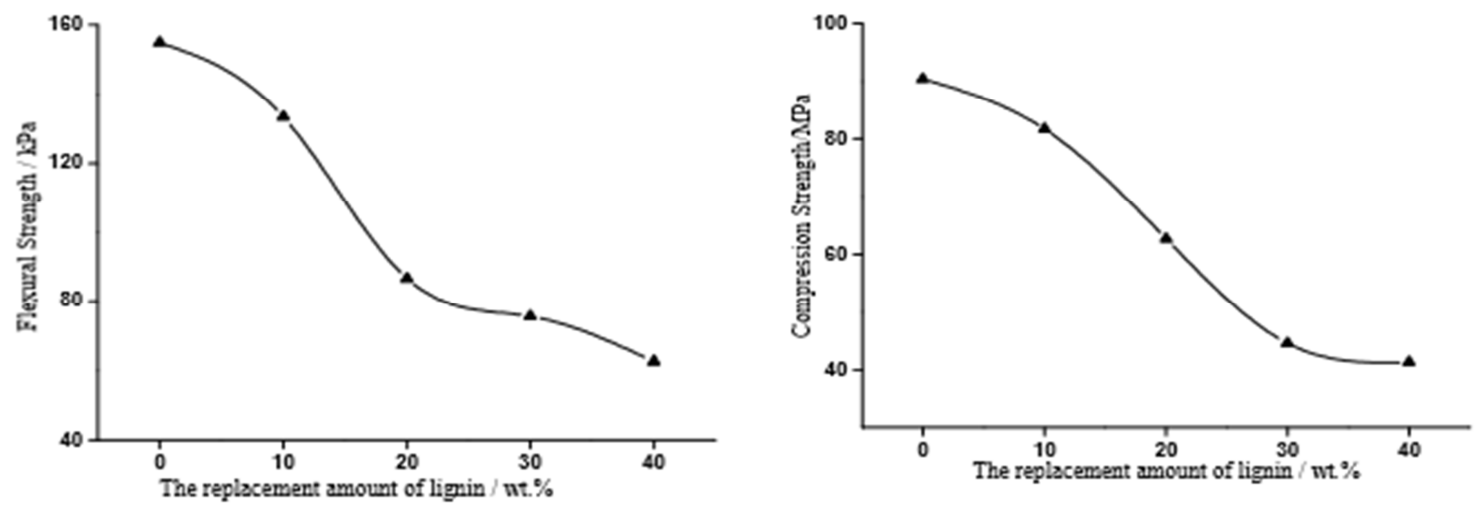

Figure 41. Lignin replacement effect on flexural strength and compressive strength of foams [111].

$\mathrm{Hu}$ et al. were interested in substituting phenol with lignosulfonate. In a first study [105], lignosulfonate and melted phenol were mixed with an aqueous sodium hydroxide solution, under certain conditions, to produce phenolated lignosulfonate. The obtained mixture was then allowed to react with formaldehyde at $80^{\circ} \mathrm{C}$ to form phenolated lignosulfonate-based resol resin. The latter, Tween 80 , n-pentane and sulphuric acid were mixed and the resulting foam cured at $70{ }^{\circ} \mathrm{C}$. The material exhibited improved mechanical properties, namely compressive strength and friability. The bio-sourced foam had a density of 0.029 with a compressive strength of $0.15 \mathrm{MPa}$, while conventional foam exhibited a compressive strength value of $0.02 \mathrm{MPa}$ for a density of 0.036 . Moreover, the mass loss during friability test dropped from $25 \%$ for conventional foams to less than $19.5 \%$ for phenolated lignosulfonate-based foams. Hence this bio-sourced phenolic resin offers very good perspectives. This can partly be due to the linear alkyl side chains in lignosulfonate structure that increases the flexibility of the foam structure in comparison with the benzene ring itself (having higher rigidity). Moreover, the modified foam presents more regular cells with a greatly reduced cell size, as illustrated in Figure 42. 


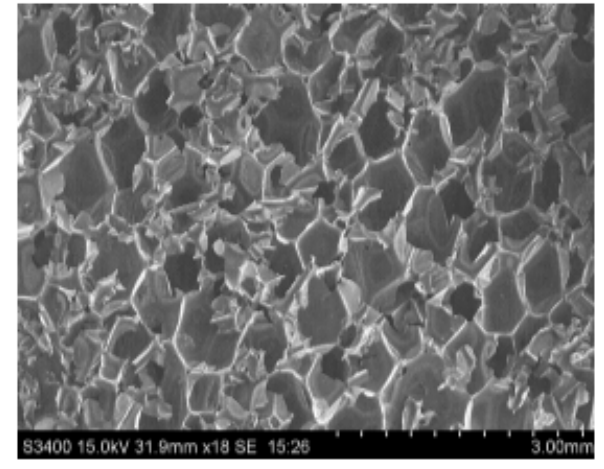

(a) conventional phenolic foam

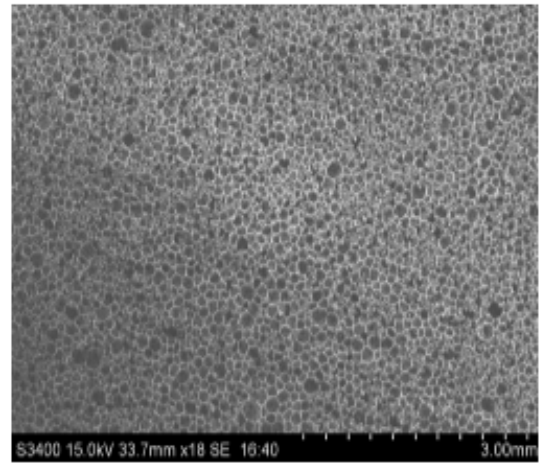

(b) modified phenolic foam

Figure 42. SEM micrographs of phenolic foams produced by Hu et al. [105].

The authors continued their investigations by modifying the resol resin using oxidatively degraded lignosulfonate $[115,116]$. Lignosulfonate modification was realized by mixing water, lignosulfonate and a sodium hydroxide solution to adjust the $\mathrm{pH}$ to 10 prior to adding $\mathrm{H}_{2} \mathrm{O}_{2}$. The mixture was heated between $40^{\circ} \mathrm{C}$ and $80^{\circ} \mathrm{C}$ for a certain period. The oxidatively degraded lignosulfonate was obtained as a dark homogeneous liquid. Modified resol resin was then prepared with this mixture through the classical pathway. As already observed for resol resin obtained from biomass, resol resins from oxidatively degraded lignosulfonate exhibited higher viscosity than that of petroleum-based resol resins (Table 15) due to the presence of numerous side chains. With increasing of phenol replacement, the free phenol and formaldehyde contents decrease while the viscosity and the solid content increase. For the foam preparation, oxidatively degraded lignosulfonate-based resol resin (30 wt\% of phenol replacement), n-pentane, Tween 80 and sulphuric acid were used. Results revealed compressive strength values of of $0.15 \mathrm{MPa}$ and $0.18 \mathrm{MPa}$ for a density of $0.050-0.055$ for modified and conventional foams, respectively. The flexural strength values were of $0.18 \mathrm{MPa}$ and $0.24 \mathrm{MPa}$ for modified and conventional foams, respectively. No explanations were given for these results.

Finally, these results can be considered quite promising for phenol substitution. However, phenolated lignosulfonate-based resins offer better perspectives than oxidatively degraded lignosulfonate-based resin.

Table 15. Properties of oxidatively degraded lignosulfonate based resol resin [116].

\begin{tabular}{c|c|c|c|c} 
Resol resin & Solid content (\%) & Viscosity (mPa.s) & $\begin{array}{c}\text { Free phenol } \\
\text { content (\%) }\end{array}$ & $\begin{array}{c}\text { Free formaldehyde } \\
\text { content (\%) }\end{array}$ \\
\hline $1: 1.70 \%$ & 72.5 & 1580 & 7.57 & 1.86 \\
$1: 1.710 \%$ & 73.8 & 2930 & 6.12 & 1.34 \\
$1: 1.720 \%$ & 74.2 & 3270 & 4.36 & 1.21
\end{tabular}




\begin{tabular}{l|l|l|l|l}
$1: 1.730 \%$ & 75.9 & 3700 & 2.92 & 0.93 \\
$1: 1.740 \%$ & 79.6 & 4150 & 1.87 & 0.64 \\
$1: 1.750 \%$ & 82.1 & 4500 & 0.65 & 0.50
\end{tabular}

Other authors have also tried to replace phenol by more original products, such as bamboo [67] and walnut shell [117]. Zhang et al. [67] prepared PF by liquefying bamboo powder at $140{ }^{\circ} \mathrm{C}$ in presence of phenol and sulphuric acid for $120 \mathrm{~min}$. Modified resol resin was then prepared under classical conditions using a sodium hydroxide solution as the catalyst. Foams were prepared using the biomass phenolic resol resin, $n$-pentane, Tween 80 and a mixture of p-toluenesulfonic acid and phosphoric acid as catalysts. Authors reported satisfactory compressive properties of the modifiedPF. Nevertheless, the study pointed out the importance of adjusting each component amount because of particular characteristics of the initial bio-based resol resin, especially its reactivity and viscosity. Moreover, infrared analysis highlighted a large amount of aromatic hydrocarbon derivatives, unsaturated bonds and ether bonds in the modified resin that would improve the toughness of the PF, in comparison with petroleum-based ones.

Huang et al. [117] prepared PF from liquefied walnut shell products in phenolic solution at $120{ }^{\circ} \mathrm{C}$, using sulfuric acid as a catalyst for $30 \mathrm{~min}$. The liquefied product was obtained with a residue of $10 \%$ unliquefied product of and $55 \%$ free phenol of. The obtained product was then allowed to react with formaldehyde, under low alkali conditions, at around $70{ }^{\circ} \mathrm{C}$ to form the biomass-based resol type phenolic resin. Diisopropyl ether $\left(B_{p}=68.4^{\circ} \mathrm{C}\right)$ was used as blowing agent for the foaming step with Tween 80 and hydrochloric acid. The resulting foam was cured at $80^{\circ} \mathrm{C}$ and showed a uniform fine cellular structure with no more precision, which is an important parameter for a foam. The final modified foam had a density of 0.030 with a compressive strength of $84 \mathrm{kPa}$ in comparison with the classical foam produced in the same conditions $(0.020,48 \mathrm{kPa})$. Using the Gibson and Ashby model for open brittle foam, a value of $89 \mathrm{kPa}$ was expected, close to what was found experimentally. To conclude on this study, the authors considered that it is easier to liquefy walnut shell than wood, even at low temperatures. Furthermore, the biomass-based resol resin was successfully applied to produce PF with comparable mechanical properties.

Cardanol, a renewable meta-substituted phenol and harmful by-product of the cashew industry, can be regarded as a versatile material for the production of bio-based PF. Nevertheless, only partial substitution of phenol with cardanol has been reported until now $[118,119]$. 
Finally, these results can be considered quite promising for phenol substitution. However, phenolated lignosulfonate-based resins offer better possibilities than oxidatively degraded lignosulfonate-based resin.

\section{Conclusions}

This review is mainly dedicated to an overview of the improvement of mechanical properties and the flame retardant properties of phenolic foams. Most of the studies are concerned by phenolic foam of density below $100 \mathrm{~kg} \mathrm{~m}^{-3}$. Only a few studies have taken into consideration foams with highest densities.

The mechanical properties are often related to the cell morphology. Actually, fibres and particles have been proved to reduce the cell size, to increase the cell density and finally to improve the cell homogeneity. Indeed, fillers play the role of nucleating agents that favour the formation of new cells. Furthermore, the increase of the viscosity of the media by the presence of the fillers limits the cell growth and the coalescence. Moreover, fillers can also play the role of surfactant and the embedded particles in the cell wall can limit the thickness reduction of cell walls, reducing the collapse and coalescence of the cells. Finally, whatever the formulations used to prepare the phenolic foams, the typical sizes of PF foams are in the range $40<D_{\text {cell }}(\mu \mathrm{m})<320$.

The improvement of the compressive properties may be obtained via different routes. Regarding fibre reinforcement, a high stiffness is required to obtain significant results, as shown with glass fibres. However, the increase of the properties is preferentially observed in the foaming direction, resulting in the loss of isotropy properties of the foam. The reinforcement by stiff particles of low aspect ratio (sphere platelets) leads also to foams with improved properties. However, for both fibre and particles, the chemical interactions between the fillers and the resin are generally critical. Indeed, when covalent bonds are created, the compressive strength is still improved because they dissipate a part of the stress generated during compression. The MWCNT and graphene oxide hybrid particles seem to be good candidates to achieve this reinforcement for compressive strength and modulus properties. Regarding chemical reinforcement, the introduction of flexible chains into the rigid backbone of the phenolic resin that are covalently linked seems to be very promising if the crosslinking density reduction is not critical. Polyurethane and polyethylene glycol family are the most used products, but dicyandiamide seems to be the most efficient.

However, it is generally difficult to separate the effect of cell morphology and density variation on the mechanical properties. Finally, we believe that density is the key factor controlling the mechanical properties 
The friability of the foam is the weakest characteristic of phenolic foam. However the friability can be significantly decreased by the addition of aramid fibres. The poor stiffness of aramid fibres decreases the friability through the micropeel process. Particles, due to their nucleating effect and covalent interactions, increase the cell density and the material cohesion, respectively, leading to a reduction of the friability. In the case of MWCNT, the embedded particles act by protection of the cell walls, causing an additional reinforcement. Chemical modifications, such as adding flexible chains into the rigid phenolic structure, improve the ability to deform without breaking, increase toughness and reduce the crosslinking density and brittleness of the foams. Nevertheless, this phenomenon is contrary to the improvement of compressive strength.

Regarding flame retardancy properties, phenolic foams have much better fire properties than all other polymer foams. In this review, two parameters were discussed: the LOI and the pHRR. For particle reinforcement, the improvement was attributed to the homogeneous dispersion of the particles that helps to reduce the oxygen permeability and offer a better separation of phenolic matrix from the air and the heat. Chemical modification containing specific elements is the most popular route for improving the fire-retardant behaviour. First, elements such as Nitrogen act as nonflammable gases sources that decrease the flammable gas concentration, hence retarding the decomposition of the underlying material. Second, phosphorous compounds, while decomposing, generate phosphorous acids that accelerate the charring process of the foams, allowing lower heat and mass transfers. The obtained char plays the role of a protective barrier.

In addition, all these modifications may increase the viscosity and modify the reactivity of the foam mixture, which are the two main characteristics of the phenolic resins. Hence, they potentially impact the foaming process by modifying the curing and foaming kinetics that have to be well controlled. If not, this may also lead to a poor distribution of the used fillers. Therefore, the formulation and process parameters may certainly need to be controlled.

Finally, one part of this review was dedicated to PF produced from biomass-based resol resin due to the great sustainable development today. Researchers tried to substitute, at least partially, the phenol with renewable biomass resources. Biomass-based resol resins from walnut shells, wood or bamboo powder demonstrated the possibility of replacement of conventional phenolic resol resins by producing foams with satisfying or similar mechanical properties. Lignin is being highly investigated and provides the most interesting results. Oxidatively degraded lignin shows better results than native lignin with mechanical properties, similar to those of conventional foams. Phenolated lignin demonstrated a high potential as it increased the compressive strength and 
decreased the friability. These improvements can be attributed due to the linear alkyl side chains in lignosulfonate structure, and to the more regular cells with a lower cell size of the microstructure. Hence, biomass-based phenolic resol resins seem to offer interesting perspectives for the development of phenolic resin with higher mechanical properties. Nevertheless, the durability of these bio-based materials has to be studied. 


\section{References}

[1] A.H. Landrock, Handbook of Plastic Foams: Types, Properties, Manufacture and Applications, Elsevier Science 1995.

[2] G.E. P. L.Mullens, R.K. Giesy, C. Thomas, Cryogenic shipping container, U.S. Pat. Appl. Publ. US 20020084277 A1 20020704 (2002)

[3] K.Y.W. Chen, Synthetic door with improved fire resistance, U.S. Pat. Appl. Publ. US 20110131921 A1 20110609 (2011)

[4] A. Gardziella, L.A. Pilato, A. Knop, Phenolic Resins: Chemistry, Applications, Standardization, Safety and Ecology, Springer (2000).

[5] L.H. Baekeland, The synthesis, constitution, and uses of bakelite, Journal of Industrial and Engineering Chemistry 1 (1909) 149-161.

[6] L.H. Baekeland, Method of making insoluble products of phenol and formaldehyde., U.S. Pat. US 942699A (1907)

[7] K. Iwasaki, Recent trends of phenolic foam in Japan, Cellular Polymers, Conference Proceedings (1991)

[8] S.R. Nutt, H. Shen, L. Vaikhanski, Composite foams for sandwich structures, J. Korean Ceram. Soc. 40(7) (2003) 625-631.

[9] M.L. Auad, L. Zhao, H. Shen, S.R. Nutt, U. Sorathia, Flammability properties and mechanical performance of epoxy modified phenolic foams, J. Appl. Polym. Sci. 104(3) (2007) 1399-1407.

[10] H. Shen, S. Nutt, Mechanical characterization of short fiber reinforced phenolic foam, Composites, Part A 34A(9) (2003) 899-906.

[11] L. Pilato, Phenolic Resins: A Century of Progress, Springer Berlin Heidelberg (2010).

[12] L. Liu, M. Fu, Z. Wang, Synthesis of Boron-Containing Toughening Agents and Their Application in Phenolic Foams, Industrial \& Engineering Chemistry Research 54(7) (2015) 1962-1970.

[13] X. Sui, Z. Wang, Flame-retardant and mechanical properties of phenolic foams toughened with polyethylene glycol phosphates, Polymers for Advanced Technologies 24(6) (2013) 593-599.

[14] M. Gao, Y.-I. Yang, Z.-q. Xu, Mechanical and flame retardant properties of phenolic foam modified with polyethylene glycol as toughening agent, Adv. Mater. Res. (Durnten-Zurich, Switz.) 803 (Frontiers of Chemical Engineering, Metallurgical Engineering and Materials II) (2013) 21-25, 6 pp.

[15] Phenolic Resins (Resols, Novolac and Others) Market for Wood-adhesives, Molding Compounds, Laminates, Insulation and Other Applications: Global Industry Perspective, Comprehensive Analysis, and Forecast, 2014 - 2020, (2016) https://www.giiresearch.com/report/zmr604263-phenolic-resinsresols-novolacs-others-market-wood.html, accessed November 5, 2018

[16] Chemical Economics Handbook - Phenolic Resins. https://ihsmarkit.com/products/phenolicresins-chemical-economics-handbook.html, accessed November 5, 2018

[17] S.A. Song, Y.S. Chung, S.S. Kim, The mechanical and thermal characteristics of phenolic foams reinforced with carbon nanoparticles, Composites Science and Technology 103 (2014) 85-93.

[18] M. Fontanille, Y. Gnanou, Chimie et physico-chimie des polymères - 2e édition, Dunod (2010).

[19] C. Michel, Phénoplastes ou phénols-formols PF, Techniques de l'Ingénieur (ref. article : a3435) (1991).

[20] B.D. Park, B. Riedl, Y.S. Kim, W.T. So, Effect of synthesis parameters on thermal behavior of phenol-formaldehyde resol resin, Journal of Applied Polymer Science 83(7) (2002) 1415-1424.

[21] X.-M. Hu, Y.-Y. Zhao, W.-M. Cheng, Effect of formaldehyde/phenol ratio (F/P) on the properties of phenolic resins and foams synthesized at room temperature, Polym. Compos. 36(8) (2015) 15311540.

[22] A. Pizzi, K.L. Mittal, Handbook of Adhesive Technology, CRC Press2017.

[23] R.A. Haupt, T. Sellers, Jr., Characterizations of Phenol-Formaldehyde Resol Resins, Industrial \& Engineering Chemistry Research 33(3) (1994) 693-697. 
[24] J.H. Freeman, Phenolic Resin Chemistry. N. J. L. MEGSON. Academic Press, New York; Butterworths, London, 1958. 323 pp. \$10.80, Journal of Polymer Science 35(129) (1959) 564-565.

[25] I.S. Chuang, G.E. Maciel, Carbon-13 NMR investigation of the stability of a resol-type phenolformaldehyde resin toward formalin, toward base, and toward nonoxidizing or oxidizing acid, Macromolecules 24(5) (1991) 1025-1032.

[26] S. So, A. Rudin, Analysis of the formation and curing reactions of resole phenolics, Journal of Applied Polymer Science 41(1-2) (1990) 205-232.

[27] O.S.U.N.E. Programme, The Montreal Protocol on Substances that Deplete the Ozone Layer as either adjusted and/or amended in London 1990, Copenhagen 1992, Vienna 1995, Montreal 1997 \& Beijing1999; NairobiKenya, (2000).

[28] D. Eaves, Handbook of Polymer Foams, Rapra Technology Ltd (2004).

[29] L.J. Gibson, M.F. Ashby, Cellular Solids: Structure and Properties, Cambridge University Press 1999.

[30] X. Li, Z. Wang, L. Wu, T. Tsai, One-step in situ synthesis of a novel [alpha]-zirconium phosphate/graphene oxide hybrid and its application in phenolic foam with enhanced mechanical strength, flame retardancy and thermal stability, RSC Advances 6(78) (2016) 74903-74912.

[31] Q. Li, L. Chen, J. Zhang, K. Zheng, X. Zhang, F. Fang, X. Tian, Enhanced mechanical properties, thermal stability of phenolic-formaldehyde foam/silica nanocomposites via in situ polymerization, Polym. Eng. Sci. 55(12) (2015) 2783-2793.

[32] K.R. Denslow, G.K. Rickle, Surfactant effects in phenolic foam resins, J. Cell. Plast. 25(1) (1989) 31-42.

[33] J.T. Zhou, Z.J. Yao, Y.X. Chen, D.B. Wei, T.S. Xu, Fabrication and Mechanical Properties of Phenolic Foam Reinforced with Graphene Oxide, Polymer Composites 35(3) (2014) 581-586.

[34] A. Desai, M.L. Auad, H. Shen, S.R. Nutt, Mechanical behavior of hybrid composite phenolic foam, J. Cell. Plast. 44(1) (2008) 15-36.

[35] Z.J. Yang, L.L. Yuan, Y.Z. Gu, M. Li, Z.J. Sun, Z.G. Zhang, Improvement in mechanical and thermal properties of phenolic foam reinforced with multiwalled carbon nanotubes, Journal of Applied Polymer Science 130(3) (2013) 1479-1488.

[36] Q. Li, L. Chen, X. Li, J. Zhang, X. Zhang, K. Zheng, F. Fang, H. Zhou, X. Tian, Effect of multi-walled carbon nanotubes on mechanical, thermal and electrical properties of phenolic foam via in-situ polymerization, Composites Part A: Applied Science and Manufacturing 82 (2016) 214-225.

[37] X. Hu, W. Cheng, W. Nie, D. Wang, Flame retardant, thermal, and mechanical properties of glass fiber/nanoclay reinforced phenol-urea-formaldehyde foam, Polym. Compos. 37(8) (2016) 2323-2332.

[38] Y.F. Ma, J.F. Wang, Y.Z. Xu, C.P. Wang, F.X. Chu, Effect of zinc oxide on properties of phenolic foams/halogen-free flame retardant system, Journal of Applied Polymer Science 132(44) (2015).

[39] C. Forest, P. Chaumont, P. Cassagnau, B. Swoboda, P. Sonntag, Polymer nano-foams for insulating applications prepared from $\mathrm{CO}_{2}$ foaming, Progress in Polymer Science 41 (2015) 122-145.

[40] A. Desai, Fiber reinforced hybrid phenolic foam, Ph.D. Publication Number: AAI3331416, University of Southern California (2008)

[41] Q. Li, L. Chen, X. Li, J. Zhang, K. Zheng, X. Zhang, X. Tian, Effect of nano-titanium nitride on thermal insulating and flame-retardant performances of phenolic foam, Journal of Applied Polymer Science 133(32) (2016) n/a-n/a.

[42] S. Jing, T. Li, X. Li, Q. Xu, J. Hu, R. Li, Phenolic foams modified by cardanol through bis-phenol modification, J. Appl. Polym. Sci. 131(4) (2014) 39942/1-39942/7.

[43] C. Yang, Z.H. Zhuang, Z.G. Yang, Pulverized Polyurethane Foam Particles Reinforced Rigid Polyurethane Foam and Phenolic Foam, Journal of Applied Polymer Science 131(1) (2014).

[44] G.K. Rickle, K.R. Denslow, The effect of water on phenolic foam cell structure, J. Cell. Plast. 24(1) (1988) 70-8.

[45] J.J. Yuan, Y.B. Zhang, Z.Z. Wang, Phenolic foams toughened with crosslinked poly (n-butyl acrylate)/silica core-shell nanocomposite particles, Journal of Applied Polymer Science 132(40) (2015). 
[46] H.Y. Yang, X. Wang, B. Yu, H.X. Yuan, L. Song, Y. Hu, R.K.K. Yuen, G.H. Yeoh, A novel polyurethane prepolymer as toughening agent: Preparation, characterization, and its influence on mechanical and flame retardant properties of phenolic foam, Journal of Applied Polymer Science 128(5) (2013) 27202728.

[47] H. Yuan, W. Xing, H. Yang, L. Song, Y. Hu, G.H. Yeoh, Mechanical and thermal properties of phenolic/glass fiber foam modified with phosphorus-containing polyurethane prepolymer, Polymer International 62(2) (2013) 273-279.

[48] C.-y. Bo, L.-h. Hu, J. Zhou, Y.-h. Zhou, Preparation and characterization of phenolic foams modified by castor oil-based polyurethane prepolymer, Linchan Huaxue Yu Gongye 35(4) (2015) 8-14.

[49] Q. Xu, R. Gong, M.Y. Cui, C. Liu, R.H. Li, Preparation of high-strength microporous phenolic opencell foams with physical foaming method, High Performance Polymers 27(7) (2014) 852-867.

[50] S.L. Rader, Phenolic foam composition and use thereof for "in place" foaming, U.S. Pat. US 5432207A (1995)

[51] V.K. Rangari, T.A. Hassan, Y. Zhou, H. Mahfuz, S. Jeelani, Synthesis, thermal and mechanical characterization of cloisite clay infused phenolic foam, SAMPE Conf. Proc. 51 (2006) 70/1-70/11.

[52] V.K. Rangari, T.A. Hassan, Y. Zhou, H. Mahfuz, S. Jeelani, B.C. Prorok, Cloisite clay-infused phenolic foam nanocomposites, J. Appl. Polym. Sci. 103(1) (2007) 308-314.

[53] M.J. Owen, C. Denis, Aspects of the Surface Chemistry of Phenolic Foam Formation, Journal of Cellular Plastics 13(4) (1977) 264-269.

[54] U. Nations, Kyoto protocol to the United Nations framework convention on climate change, (1998).

[55] M. Rochefort, L. Ripley, P. Holland, V. Coppock, Phenolic foam, UK Pat. Appl. GB 2505974 A (2014).

[56] B. Del Saz-Orozco, M.V. Alonso, M. Oliet, J.C. Dominguez, F. Rodriguez, Mechanical, thermal and morphological characterization of cellulose fiber-reinforced phenolic foams, Composites Part BEngineering 75 (2015) 367-372.

[57] H. Yu, L. Wang, G. Gai, Performance of Modified Aramid Fiber Reinforced Phenolic Foam, Advanced Materials Research 557-559 (2012) 258-261.

[58] Y.X. Zuo, Z.J. Yao, J.T. Zhou, Mechanical and Thermal Properties of Phenolic Foams Reinforced by Hollow Glass Beads, Advanced Materials Research 988 (2014) 13-22.

[59] H. Yang, X. Wang, H. Yuan, L. Song, Y. Hu, R.K.K. Yuen, Fire performance and mechanical properties of phenolic foams modified by phosphorus-containing polyethers, Journal of Polymer Research 19(3) (2012) 9831.

[60] Z. Eslami, F. Yazdani, M.A. Mirzapour, Thermal and mechanical properties of phenolic-based composites reinforced by carbon fibres and multiwall carbon nanotubes, Composites Part A: Applied Science and Manufacturing 72 (2015) 22-31.

[61] B. Del Saz-Orozco, M.V. Alonso, M. Oliet, J.C. Domínguez, E. Rojo, F. Rodriguez, Lignin particleand wood flour-reinforced phenolic foams: Friability, thermal stability and effect of hygrothermal aging on mechanical properties and morphology, Composites Part B: Engineering 80 (2015) 154-161.

[62] J. Choe, M. Kim, J. Kim, D.G. Lee, A microwave foaming method for fabricating glass fiber reinforced phenolic foam, Composite Structures 152 (Supplement C) (2016) 239-246.

[63] R.H. Sefton, J.D. Carlson, Process for producing phenolic foams with a uniform appearance, U.S. Patent, US4165413A (1979)

[64] N. Meyer, G. Wollaert, Continuous process for the manufacture of quick-setting phenolic foams, U.S. Patent, 4,424,289 (1984)

[65] S.A. Song, H.J. Oh, B.G. Kim, S.S. Kim, Novel foaming methods to fabricate activated carbon reinforced microcellular phenolic foams, Composites Science and Technology 76 (2013) 45-51.

[66] J. Wolfrum, G.W. Ehrenstein, Interdependence between the curing, structure, and the mechanical properties of phenolic resins, Journal of Applied Polymer Science 74(13) (1999) 31733185.

[67] J. Zhang, M. Du, Bamboo powder liquefaction and resinification: application on the phenolic foam, Mater. Sci. Forum 743-744 (Energy and Environment Materials) (2013) 306-311 
[68] M.W. Schraad, F.H. Harlow, A stochastic constitutive model for disordered cellular materials: Finite-strain uni-axial compression, International Journal of Solids and Structures 43(11) (2006) 35423568.

[69] W.E. Warren, A.M. Kraynik, The Linear Elastic Properties of Open-Cell Foams, Journal of Applied Mechanics 55(2) (1988) 341-346.

[70] R.M. Christensen, Mechanics of low density materials, Journal of the Mechanics and Physics of Solids 34(6) (1986) 563-578.

[71] H. Liu, C. Han, L. Dong, Study on the cell structure and compressive behavior of biodegradable poly(c-caprolactone) foam, Polymer Engineering \& Science 48(12) (2008) 2432-2438.

[72] R. Brezny, D.J. Green, The effect of cell size on the mechanical behavior of cellular materials, Acta Metallurgica et Materialia 38(12) (1990) 2517-2526.

[73] H. Yu, Z. Guo, B. Li, G. Yao, H. Luo, Y. Liu, Research into the effect of cell diameter of aluminum foam on its compressive and energy absorption properties, Materials Science and Engineering: $A$ 454-455 (2007) 542-546.

[74] Z.G. Xu, J.W. Fu, T.J. Luo, Y.S. Yang, Effects of cell size on quasi-static compressive properties of Mg alloy foams, Materials \& Design 34 (2012) 40-44.

[75] Y. Chen, R. Das, M. Battley, Effects of cell size and cell wall thickness variations on the stiffness of closed-cell foams, International Journal of Solids and Structures 52 (2015) 150-164.

[76] C. Gaétane, Elaboration et caractérisation de matériaux polymères poreux modèles à base d'émulsions contrôlées, Numéro d'ordre 4462, UNIVERSITÉ BORDEAUX 1 (2012).

[77] B. Pascal, Émulsification Élaboration et étude des émulsions, Techniques de I'Ingénieur Cosmétiques base documentaire : TIB634DUO (ref. article : j2150) (2013).

[78] S.U. Pickering, CXCVI.-Emulsions, Journal of the Chemical Society, Transactions 91(0) (1907) 2001-2021.

[79] R. Aveyard, B.P. Binks, J.H. Clint, Emulsions stabilised solely by colloidal particles, Advances in Colloid and Interface Science 100-102 (2003) 503-546.

[80] Z.H. Zhuang, B. He, Z.G. Yang, Preparation and characterisation of phenolic foam/HTAB-ATP nanocomposites, Plast., Rubber Compos. 39(10) (2010) 460-464.

[81] Y. Zuo, Z. Yao, J. Zhou, Mechanical and thermal properties of phenolic foams reinforced by hollow glass beads, Adv. Mater. Res. (Durnten-Zurich, Switz.) 988 (Material, Mechanical and Manufacturing Engineering II) (2014) 13-22

[82] L. Li, Y. Xu, C. Wang, F. Chu, Preparation and characterization of phenolic foam modified by nitrile butadiene rubber powder, Appl. Mech. Mater. 204-208(Pt. 5, Progress in Industrial and Civil Engineering) (2012) 4137-4142.

[83] H.Y. Ding, J.F. Wang, J. Liu, Y.Z. Xu, R.Q. Chen, C.P. Wang, F.X. Chu, Preparation and properties of a novel flame retardant polyurethane quasi-prepolymer for toughening phenolic foam, Journal of Applied Polymer Science 132(35) (2015).

[84] H. Shen, S. Nutt, D. Hull, Direct observation and measurement of fiber architecture in short fiberpolymer composite foam through micro-CT imaging, Compos. Sci. Technol. 64(13-14) (2004) 21132120.

[85] Y. Ma, X. Geng, X. Zhang, C. Wang, F. Chu, A novel DOPO-g-KH550 modification wood fibers and its effects on the properties of composite phenolic foams, Polish Journal of Chemical Technology 20(2) (2018) 47-53

[86] P. Liu, G.F. Chen, Porous Materials: Processing and Applications, Elsevier Science 2014.

[87] X. Li, Z. Wang, L. Wu, Preparation of a silica nanospheres/graphene oxide hybrid and its application in phenolic foams with improved mechanical strengths, friability and flame retardancy, RSC Adv. 5(121) (2015) 99907-99913.

[88] Z. Yang, L. Yuan, Y. Gu, M. Li, Z. Sun, Z. Zhang, Improvement in mechanical and thermal properties of phenolic foam reinforced with multiwalled carbon nanotubes, J. Appl. Polym. Sci. 130(3) (2013) 1479-1488.

[89] K. Yu, X. Luo, M. Wang, K. Qian, Preparation and characterization of phenolic foam reinforced with expandable graphite and expanded graphite, Journal of Cellular Plastics 54(3) (2018) 545-559. 
[90] L. Liu, Z. Wang, Facile synthesis of a novel magnesium amino-tris-(methylenephosphonate)reduced graphene oxide hybrid and its high performance in mechanical strength, thermal stability, smoke suppression and flame retardancy in phenolic foam, Journal of Hazardous Materials 357 (2018) 89-99.

[91] X. Luo, K. Yu, K. Qian, Morphologies and compression performance of graphene oxide/SiO2 modified phenolic foam, High Performance Polymers 30(7) (2018) 803-811.

[92] Z. Wang, X. Li, Synthesis of CoAl-layered double hydroxide/graphene oxide nanohybrid and its reinforcing effect in phenolic foams, High Performance Polymers 30(6) (2018) 688-698.

[93] L. Li, Y.-Z. Xu, C.-P. Wang, F.-X. Chu, Properties and microstructure of phenolic foam modified by nitrile butadiene rubber powder, Linchan Huaxue Yu Gongye 33(2) (2013) 31-36.

[94] Y. Guo, L. Hu, C. Bo, Q. Shang, G. Feng, P. Jia, B. Zhang, Y. Zhou, Mechanical property of ligninmodified phenolic foam enhanced by nano-SiO2 via a novel method, Chemical Papers 72(3) (2018) 763-767.

[95] M. Gao, W. Wu, Y. Wang, Y. Wang, H. Wang, Phenolic foam modified with dicyandiamide as toughening agent, J. Therm. Anal. Calorim. 124(1) (2016) 189-195.

[96] L. Hu, Z. Wang, Q. Zhao, Flame Retardant and Mechanical Properties of Toughened Phenolic Foams Containing a Melamine Phosphate Borate, Polymer-Plastics Technology and Engineering 56(6) (2017) 678-686.

[97] F. Riahi, R. Doufnoune, C. Bouremel, Subtitution of Pentane by a Mineral Clay as a Blowing Agent for Phenolic Foam, Int. J. Polym. Mater. 56(9) (2007) 929-938.

[98] Y.F. Yang, J.M. He, Mechanical characterization of phenolic foams modified by short glass fibers and polyurethane prepolymer, Polymer Composites 36(9) (2015) 1584-1589.

[99] H. Shen, A.J. Lavoie, S.R. Nutt, Enhanced peel resistance of fiber reinforced phenolic foams, Composites, Part A 34A(10) (2003) 941-948.

[100] ISO 4589-3:1996, 1996.

[101] M. Niu, G. Wang, Study on the nanocomposite foam of cardanol phenolic resin and organomodified montmorillonite, Adv. Mater. Res. (Durnten-Zurich, Switz.) 712-715 (2013) 147-155.

[102] U. Braun, A.I. Balabanovich, B. Schartel, U. Knoll, J. Artner, M. Ciesielski, M. Döring, R. Perez, J.K.W. Sandler, V. Altstädt, T. Hoffmann, D. Pospiech, Influence of the oxidation state of phosphorus on the decomposition and fire behaviour of flame-retarded epoxy resin composites, Polymer $47(26)$ (2006) 8495-8508.

[103] M. Lewin, E. D. Weil, Mechanisms and Modes of Action in Flame Retardancy of Polymers, Fire Retardant Materials A. Richard Horrocks, D. Price Editors, CRC (2001) 31-68

[104] A. König, E. Kroke, Methyl-DOPO-a new flame retardant for flexible polyurethane foam, Polymers for Advanced Technologies 22(1) (2011) 5-13.

[105] L. Hu, Y. Zhou, M. Zhang, R. Liu, Characterization and properties of a lignosulfonate-based phenolic foam, BioResources 7(1) (2012) 554-564.

[106] Y. Cui, J. Chang, W. Wang, Fabrication of Glass Fiber Reinforced Composites Based on Bio-Oil Phenol Formaldehyde Resin, Materials 9 (2016) 886-896

[107] Y. Cui, X. Hou, W. Wang, J. Chang, Synthesis and Characterization of Bio-Oil Phenol, Formaldehyde Resin Used to Fabricate Phenolic Based Materials, Materials 10 (2017) 668-677

[108] B. Li, Y. Wang, N. Mahmood, Z. Yuan, J. Schmidt, C. Xu, Preparation of bio-based phenol formaldehyde foams using depolymerized hydrolysis lignin, Industrial Crops and Products 97 (2017) 409-416.

[109] S.-H. Lee, Y. Teramoto, N. Shiraishi, Resol-type phenolic resin from liquefied phenolated wood and its application to phenolic foam, J. Appl. Polym. Sci. 84(3) (2002) 468-472.

[110] B. Li, S.H. Feng, H.S. Niasar, Y.S. Zhang, Z.S. Yuan, J. Schmidt, C. Xu, Preparation and characterization of bark-derived phenol formaldehyde foams, RSC Advances 6(47) (2016) 4097540981. 
[111] X. Zhuang, S. Li, Y. Ma, W. Zhang, Y. Xu, C. Wang, F. Chu, Preparation and characterization of lignin-phenolic foam, Adv. Mater. Res. (Durnten-Zurich, Switz.) 236-238 (Pt. 1, Application of Chemical Engineering) (2011) 1014-1018.

[112] Y. Wang, H. Wang, H. Lin, Y. Zheng, J. Zhao, A. Pelletier, K. Li, Effects of solvents and catalysts in liquefaction of pinewood sawdust for the production of bio-oils, Biomass and Bioenergy 59 (2013) 158-167.

[113] S. Cheng, Z. Yuan, M. Leitch, M. Anderson, C. Xu, Highly efficient de-polymerization of organosolv lignin using a catalytic hydrothermal process and production of phenolic resins/adhesives with the depolymerized lignin as a substitute for phenol at a high substitution ratio, Industrial Crops and Products 44 (2013) 315-322.

[114] S.-H. Lee, M. Yoshioka, N. Shiraishi, Liquefaction and product identification of corn bran (CB) in phenol, Journal of Applied Polymer Science 78(2) (2000) 311-318.

[115] L. Hu, Y. Zhou, R. Liu, M. Zhang, Phenolic foam from oxidatively degraded lignosulphonate, Adv. Mater. Res. (Durnten-Zurich, Switz.) 581-582 (Pt. 1, Frontiers of Materials, Chemical and Metallurgical Technologies) (2012) 238-241.

[116] L. Hu, Y. Zhou, R. Liu, M. Zhang, X. Yang, Synthesis of foaming resol resin modified with oxidatively degraded lignosulfonate, Ind. Crops Prod. 44 (2013) 364-366.

[117] Y. Huang, Z. Zheng, H. Feng, H. Pan, Phenolic foam from liquefied products of walnut shell in phenol, Adv. Mater. Res. (Durnten-Zurich, Switz.) 236-238(Pt. 1, Application of Chemical Engineering) (2011) 241-246.

[118] B. Liang, X. Li, L. Hu, C. Bo, J. Zhou, Y. Zhou, Foaming resol resin modified with polyhydroxylated cardanol and its application to phenolic foams, Ind. Crops Prod. 80 (2016) 194-196.

[119] C. Bo, L. Hu, Y. Chen, X. Yang, M. Zhang, Y. Zhou, Synthesis of a novel cardanol-based compound and environmentally sustainable production of phenolic foam, Journal of Materials Science 53(15) (2018) 10784-10797. 


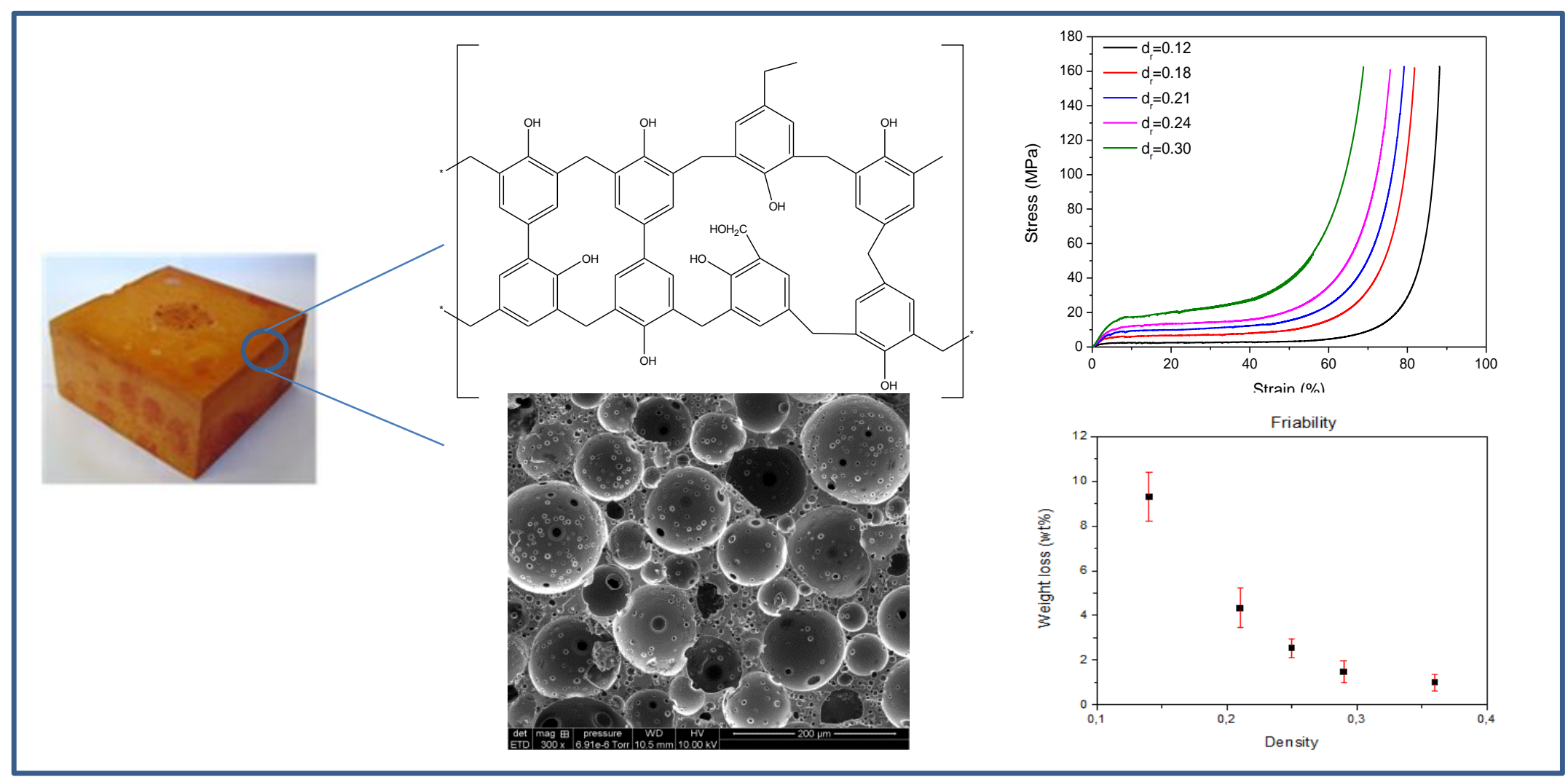

